DUCE, Mauricio; COUSO, Jaime. "El derecho a un juzgamiento especializado de los jóvenes infractores en el derecho comparado".

Polit. crim. Vol. 7, No 13 (Julio 2012), Art. 1, pp. 1 - 73.

[http://www.politicacriminal.cl/Vol_07/n_13/Vol7N13A1.pdf]

\title{
El Derecho a un Juzgamiento Especializado de los Jóvenes Infractores en el Derecho Comparado*
}

\author{
Mauricio Duce \\ Profesor Titular, Facultad de Derecho, Universidad Diego Portales \\ mauricio.duce@udp.cl \\ Jaime Couso \\ Profesor Titular, Facultad de Derecho, Universidad Diego Portales \\ jaime.couso@mail.udp.cl
}

\section{Resumen}

El presente trabajo corresponde a la segunda parte de una investigación realizada con el propósito de revisar los alcances del derecho a un juzgamiento especializado de los jóvenes que cometen delitos. El proyecto ha identificado la existencia de estándares especiales para el juzgamiento de niños y adolescentes por infracciones penales contenidos en el derecho internacional de los derechos humanos y luego ha pretendido establecer la manera en que ellos son recogidos por las legislaciones nacionales en diversos países. En este contexto, el objetivo específico del presente trabajo es analizar la forma en que dicho derecho ha sido regulado en la normativa y la práctica jurisprudencial en cuatro países de importancia e influencia en el diseño del sistema nacional como son: Alemania, Costa Rica, España y Estados Unidos. La regulación de este derecho es analizado en dos ejes centrales: reforzamiento del debido proceso y aspectos de estructura procesal. El trabajo permite identificar la existencia de diversos mecanismos legales desarrollados en el derecho comparado que tienen por propósito asegurar el derecho a un juzgamiento especializado de los jóvenes infractores.

\section{Palabras clave}

Proceso penal juvenil, derecho comparado, juzgamiento especializado.

\footnotetext{
* Este trabajo ha sido elaborado en el marco del proyecto Fondecyt Regular No 1080644, "El Principio de Especialidad en el Derecho Penal y Procesal Penal de Adolescentes. Análisis Dogmático y Jurisprudencial”; Investigador Responsable: Jaime Couso; Co-Investigador: Mauricio Duce. Los autores agradecen el valioso apoyo de investigación para la elaboración de este trabajo realizado por la ayudante del proyecto, Andrea Collell. Los autores también agradecen el apoyo prestado por Jaime Cerda, alumno ayudante del Departamento de Derecho penal y procesal penal de la Facultad de Derecho de la UDP, en la revisión final del texto y ajuste de las notas a pie de página.
} 
DUCE, Mauricio; COUSO, Jaime. "El derecho a un juzgamiento especializado de los jóvenes infractores en el derecho comparado".

\begin{abstract}
This paper is the second part of an investigation made with the purpose of reviewing the scope of the right of juveniles to be judged by a specialized system in criminal cases in comparison with the prosecution of crimes committed by adults. The project established that there are special standards developed in the subject in international human rights law and also attempted to identify their use in national legislations in several countries. In this context, the specific goal of the paper is to analyze how this right has been introduced and the way in which High Courts have developed their contents in the case law in four countries that have been very influential in the design of the new Chilean juvenile system: Costa Rica, Germany, Spain and The United States of America. For that purpose the paper focuses its analysis in two main axes: strengthening of due process guarantees and aspects of procedural structure. The paper identifies several legal tools developed in the comparative law that allow fulfilling the rights of the juveniles to be judged by a specialized system.
\end{abstract}

\title{
Key words
}

Juvenile criminal procedure, comparative law, specialized judgment.

\section{Introducción}

En un trabajo anterior hemos tenido oportunidad de revisar como el derecho a un juzgamiento especializado de los jóvenes que cometen delitos ha sido consagrado ampliamente en el derecho internacional de los derechos humanos (tantos en normas internacionales generales como en otros instrumentos especializados). ${ }^{1}$ Hemos denominado a este derecho como el principio de especialidad. Además, pudimos constatar que el sistema internacional ha precisado a través de sus normas, jurisprudencia y distintas recomendaciones e instrumentos los principales alcances y contenidos de este derecho. En dicha oportunidad identificamos que el derecho a un juzgamiento especializado, de acuerdo a su regulación en el derecho internacional de los derechos humanos, se traducía en el desarrollo de tres ejes centrales en los cuales las legislaciones nacionales deben contemplar regulaciones especiales tratándose de niños o jóvenes infractores. Estos tres ejes fueron identificados como: reforzamiento del debido proceso; aspectos de estructura procesal; y, necesidad de contar una política amplia de diversificación de respuestas y desestimación de casos. $^{2}$

\footnotetext{
${ }^{1}$ Véase DUCE, Mauricio, "El Derecho a un Juzgamiento Especializado de los Jóvenes Infractores en el Derecho Internacional de los Derechos Humanos y su Impacto en el Diseño del Proceso Penal Juvenil”, Ius et Praxis, año $15-\mathrm{n}^{\mathrm{o}} 1$ (2009), pp. 73 a 120.

${ }^{2}$ Al igual que el trabajo antes referido, no será parte de este texto el análisis del impacto que debiera tener el derecho ser juzgado por un sistema especializado a nivel de las reglas que regulan los aspectos de diseño orgánico del sistema de justicia juvenil por infracciones a la ley penal. La razón de no abordar los aspectos orgánicos se debe a que esta dimensión lleva al análisis de los más diversos tipos de arreglos institucionales, tanto respecto a la forma de organizar a las instituciones que integran al sistema de justicia, como en sus sistemas de capacitación y entrenamiento, selección de personal, entre otras múltiples variables que nos alejan de los aspectos en los que más directamente recae la legislación procesal propiamente tal y sobre los cuales se
} 
Polit. crim. Vol. 7, No 13 (Julio 2012), Art. 1, pp. 1 - 73.

[http://www.politicacriminal.cl/Vol_07/n_13/Vol7N13A1.pdf]

En el contexto descrito, el presente trabajo pretende revisar la manera en que estos criterios y estándares desarrollados en el ámbito del derecho internacional de los derechos humanos han sido recogidos en el derecho comparado marcando un tratamiento especial en el juzgamiento por infracciones a la ley penal de los niños y jóvenes respecto de los adultos. En consecuencia, a partir de la identificación que hemos realizado de los ejes en donde se debiera focalizar la regulación especializada a nivel nacional se intentará determinar el cómo ellas han sido recogidas y desarrolladas por la legislación, jurisprudencia y doctrina comparada. Con todo, debido a la amplitud del tema y a la gran diversidad de herramientas legales contempladas en el derecho comparado, en este trabajo hemos limitado nuestro análisis a dos de los ejes: reforzamiento del debido proceso y aspectos de estructura procesal. Cabe señalar que al elegir los dos ejes y examinar los temas que en cada uno de ellos hemos seleccionado, estamos dejando algunas manifestaciones del derecho al juzgamiento especializado fuera de nuestro análisis. En este sentido el trabajo no pretende cubrir exhaustivamente todas las manifestaciones posibles de este derecho sino sólo aquellas que nos han parecido más centrales y que son posibles de ser rastreadas en las legislaciones nacionales.

Como podrá apreciar el lector, la tarea de describir la forma en que estos ejes han sido reconocidos y desarrollados en el derecho comparado en forma amplia resulta impracticable para un trabajo con objetivos acotados como el presente. Como ha sido señalado por un destacado especialista en derecho comparado, la diversidad de arreglos en los cuales se organizan los sistemas judiciales es inmensa e imposible de abarcar. ${ }^{3}$ Esto es igualmente cierto -e incluso se agrava- tratándose de los sistemas de responsabilidad juvenil en donde pareciera haber menos niveles de acuerdo acerca de un modelo básico a partir de los objetivos que debieran inspirar al sistema. ${ }^{4}$ Esto lleva a que se constate en el ámbito comparado una tendencia a una cada vez mayor complejidad y mixtura en los sistemas que lidian con la justicia juvenil. ${ }^{5}$

pronuncia la jurisprudencia. Con todo, nos parece indispensable dejar en claro que dicha dimensión es esencial para el cumplimiento adecuado tanto de los aspectos procesales como los substantivos del derecho a un juzgamiento especializado. Esta opción no significa, en todo caso, que algunas cuestiones que revisaremos en el presente texto no tengan un impacto en aspectos orgánicos del sistema, sino simplemente que el enfoque del trabajo no es abordar desde un punto de vista orgánico las consecuencias del derecho de los jóvenes a ser juzgado en un sistema especializado.

${ }^{3}$ Véase DAMASKA, Mirjan, The Faces of Justice and State Authority: A Comparative Approach to the Legal Process, New Haven: Yale University Press, 1986, p. 1.

${ }^{4}$ En este sentido, véase TONRY, Michael; DOOB, Anthony, "Varieties of Youth Justice", en: TONRY, Michael; DOOB, Anthony (Eds.), Youth Crime and Youth Justice: Comparative and Cross-National Perspectives, Chicago: The University of Chicago Press, 2004, pp. 1-21, especialmente, p. 3. Un análisis de diversos modelos que compiten en el ámbito comparado europeo puede verse en DÜNKEL, Frieder, "Reacciones en los Campos de la Administración de Justicia y la Pedagogía Social a la Delincuencia Infantil y Juvenil: Un Estudio Comparativo a Escala Europea”, en: TIFFER, Carlos; LLOBET, Javier; DÜNKEL, Frieder, Derecho Penal Juvenil, San José: ILANUD-DAAD, 2002, pp. 543 a 619.

5 Véase MUNCIE, John; GOLDSON, Barry, "States of Transition: Convergence and Diversity in International Youth justice”, en: MUNCIE, John; GOLDSON, Barry (Eds.), Comparative Youth Justice, Londres: SAGE, 2006, pp. 196-197. 
DUCE, Mauricio; COUSO, Jaime. "El derecho a un juzgamiento especializado de los jóvenes infractores en el derecho comparado".

No obstante la Convención de Derechos del Niño (en adelante la Convención) ha sido ratificada por prácticamente todos los Estados a nivel mundial ${ }^{6}$ y por vía de ella se han introducido exigencias comunes a todos los países que debieran llevar a la convergencia de los sistemas legales, ello choca con la práctica en cómo dichos mandatos se articulan y respetan a nivel interno. Así, en opinión de algunos autores, es posible constatar que siendo la Convención el tratado internacional que cuenta con el mayor número de ratificaciones en el área del derecho internacional de los derechos humanos, es también el que mayores niveles de violación presenta por los Estados partes. ${ }^{7}$ A todo lo anterior debe sumarse la gran distancia que existe en esta materia entre el derecho en los libros y su funcionamiento práctico, lo que dificulta aún más el trabajo de estudio comparado. ${ }^{8}$

En este complejo escenario, el análisis comparado que pretende realizar este trabajo se ha sido limitado a cuatro países de diversas tradiciones jurídicas y ubicación geográfica que representan modelos paradigmáticos de implementación de sistemas de responsabilidad especial para los niños y jóvenes y que tradicionalmente han sido de mucho influencia en nuestra legislación. Se trata específicamente de Alemania, Costa Rica, España y Estados Unidos. En el caso de España y Costa Rica, el propio Mensaje del Ejecutivo del Proyecto de Ley de nuestra actual Ley de Responsabilidad de los Adolescentes por Infracciones a la Ley Penal (en adelante LRPA) los señaló como fuentes directas de inspiración (Mensaje 68-347 de 2 de agosto de 2002, página 9). Estados Unidos y Alemania, en cambio, se eligen por la enorme influencia cultural que poseen como modelos de derecho comparado que inspiran a una cantidad importante de países, entre ellos también a España y Costa Rica.

Con ello pretendemos limitar el problema de la extrema diversidad de alternativas de análisis a la vez que nos permite profundizar el análisis de cada caso. Para ello, en cada uno de los países objeto de estudio hemos revisado la legislación pertinente y lo que la doctrina nacional ha escrito sobre la estructura de su sistema. Para evitar que el trabajo sea sólo una descripción del "derecho en los libros" hemos incluido en nuestra investigación la revisión de jurisprudencia relevante en todas estas jurisdicciones y, en tres de los países, hemos realizado entrevistas con expertos locales que han intentado indagar en la práctica específica del sistema en su respectivo país. ${ }^{9}$ Si bien este trabajo no tiene una pretensión de realizar una caracterización empírica detallada de los sistemas objeto de estudio, sí nos interesa describir, al máximo de lo posible, no sólo los diseños legales de estos países sino

\footnotetext{
${ }^{6}$ Estados Unidos sigue siendo uno de los pocos países (si no el único) que no la han ratificado e incorporado a su legislación interna.

${ }^{7}$ Véase MUNCIE / GOLDSON, "States of Transition", cit. nota n 5, p. 212. Citando un estudio de Abramson del año 2000 realizado en 141 países signatarios de la Convención se constata una falta de "comprensión simpática" ("sympathetic understanding") necesaria para su adecuado cumplimiento.

${ }^{8}$ Véase TONRY / DOOB, "Varieties", cit. nota no 4, pp. 16-19.

9 En Alemania fueron entrevistados los profesores Ulrich Eisenberg, emérito de la Universidad Libre de Berlín, el 30 de abril de 2008 y Frieder Dünkel, profesor de la Universidad de Greifswald, el 5 de mayo de 2008. En España se entrevistó a Francisco Manuel García Ingelmo, Fiscal de Menores, Fiscalía del Tribunal Superior de Justicia de Madrid, quien fue entrevistado personalmente en Madrid el 12 de mayo de 2008 y luego dicha entrevista fue complementada a través de correo electrónico de 23 de mayo de 2008 . Todas estas entrevistas fueron realizadas por el director del proyecto, Jaime Couso. En el caso de Costa Rica se entrevistó a Carlos Tiffer el día 10 de octubre de 2008, por la ayudante del proyecto Andrea Collell.
} 
Polít. crim. Vol. 7, N 13 (Julio 2012), Art. 1, pp. 1 - 73.

[http://www.politicacriminal.cl/Vol_07/n_13/Vol7N13A1.pdf]

la forma en que dichos diseños operan en la práctica, especialmente en cómo han sido recibidos y comprendidos por la práctica jurisprudencial.

Para cumplir con los objetivos descritos, el presente trabajo se divide en cinco capítulos incluyendo dentro de ellos esta introducción. El capítulo dos estará destinado a realizar una breve explicación introductoria de los cuatro sistemas jurídicos seleccionados. Para ello se entregarán algunos datos generales sobre el sistema legal vigente en cada uno de ellos. Los capítulos tres y cuatro estarán destinados a revisar la forma en que han sido recogidos los elementos centrales del derecho a un juzgamiento especializado de los jóvenes infractores, agrupados en los dos ejes que ya han sido mencionados: reforzamiento del debido proceso (capítulo tres) y aspectos de estructura procesal (capítulo cuatro). El trabajo finalizará en su capítulo cinco con algunas breves conclusiones y comentarios generales. Se puede apreciar que hemos restringido nuestro análisis a dos de los tres ejes identificados debido a la extensión y complejidad que ha tenido la investigación. Hemos preferido centrarnos en dos temas que nos permiten lograr más profundidad y en los que hemos podido identificar mayor información en cada uno de los sistemas objeto de nuestro estudio.

\section{Explicación Panorámica de los Sistemas Objeto de Estudio}

Como hemos indicado en la introducción, nuestro análisis de derecho comparado ha sido restringido al caso de las legislaciones especiales juveniles de cuatro países. Se trata de Alemania y España en Europa y de Costa Rica y Estados Unidos en las Américas. Nos parece que estos cuatro ejemplos constituyen casos paradigmáticos de la diversidad de organizaciones de sistemas especializados juveniles que comparten principios similares a los que se han tenido a la vista en la elaboración del sistema nacional (y que tradicionalmente han sido muy influyentes en esta materia), pero además que cuentan con un asentamiento doctrinario y jurisprudencial importante que permite un trabajo de investigación de esta naturaleza.

Se trata de cuatro ejemplos que parten de la base de la idea de la especialidad que debe tener el juzgamiento de jóvenes infractores en relación con el tratamiento que reciben los adultos. Así, por ejemplo, el mensaje de la Ley Orgánica 5/2000 de España (Ley Reguladora de la Responsabilidad Penal de los Menores en adelante "LO 5/2000") señala en su párrafo 4 acerca los objetivos tenidos en vista al elaborarse que "(...)asentando firmemente el principio de que la responsabilidad penal de los menores presenta frente a la de los adultos un carácter primordial de intervención educativa que trasciende a todos los aspectos de su regulación jurídica y que determina considerables diferencias entre el sentido y el procedimiento de las sanciones en uno y otro sector, sin perjuicio de las garantías comunes a todo justiciable.” Ideas similares han sido expresadas por la doctrina que describe al sistema de responsabilidad penal juvenil de Costa Rica establecido el año $1996,{ }^{10}$ y por la jurisprudencia en Alemana ${ }^{11}$ y en los Estados Unidos. ${ }^{12}$

\footnotetext{
${ }^{10}$ Entre otros véase ROJAS, Alejandro, "El Derecho de Defensa en el Proceso Penal Juvenil Costarricense", en: GONZALEZ, Mauricio; TIFFER, Carlos (Coords.) De la Arbitrariedad a la Justicia: Adolescentes y Responsabilidad penal en Costa Rica, San José: UNICEF, 2000, pp. 345 a 348.

${ }^{11}$ Donde, como ha declarado el Tribunal Constitucional Federal alemán, la orientación del Derecho penal juvenil (o de adolescentes) a la prevención especial positiva, para promover una vida futura sin delitos,
} 
DUCE, Mauricio; COUSO, Jaime. "El derecho a un juzgamiento especializado de los jóvenes infractores en el derecho comparado".

A continuación revisaremos de manera somera cuáles son las bases estructurales en la configuración de los sistemas procesales juveniles en los cuatro países seleccionados. La idea de esta presentación es que ella sirva de marco que facilite la comprensión de los distintos temas específicos que analizaremos a propósito de los dos ejes objeto de análisis en este trabajo.

\subsection{Alemania ${ }^{13}$}

Alemania cuenta con una legislación penal especial para menores de edad desde 1923, año de la promulgación de la Ley de Tribunales Juveniles (Jugendgerichtsgesetz, en adelante también JGG). La JGG de 1923 fue posteriormente sustituida por la Ley de Tribunales Juveniles del Imperio, la RJGG de 1943, dictada por los nazis en plena segunda guerra mundial, y más tarde, por la JGG de 1953. Esta última, si bien tras una importante reforma el año 1990, es la que se encuentra actualmente vigente. ${ }^{14}$

La JGG se aplica a adolescentes de entre 14 y 18 años de edad, así como a los jóvenes mayores de 18 y menores de 21 años de edad que tengan una madurez ("desarrollo moral y mental") propia de un adolescente o que hayan cometido una infracción penal propia de adolescentes ( $\$ 105$ de la JGG).

constituye, bajo la idea del "principio educativo", la base de todas las reglas de esa rama del derecho (citado por LAUBENTHAL, Klaus; BAIER, Helmut, Jugendstrafrecht, Springer: Berlín-Heidelberg-Nueva York, 2005, p. 2).

${ }^{12}$ Aunque en los comentarios de las leyes de tribunales juveniles estaduales se puede encontrar una retórica similar, el caso de la jurisdicción federal de los Estados Unidos (la que es objeto de estudio en este trabajo) es peculiar, pues, a partir de una larga tradición de tribunales especiales para menores en los Estados Unidos de América, fundados en la especial situación del delincuente menor de edad, la jurisprudencia constitucional, desde los años sesenta del siglo XX ha ido eliminando diferencias en lo que respecta a la aplicación de garantías del debido proceso, salvo cuando en casos muy puntuales ha decidido, amparada precisamente en el carácter especial de los procedimientos de menores, excluir la aplicación alguna garantía propia de los procesos penales de adultos (así, en McKeiver v. Pennsylvania v. Pennsylvania (403 U.S. 528, 1971), cuando negó extender a los menores de edad el derecho a un juicio por jurado, pues ello "destruiría el carácter tradicional de los procedimientos de menores").

${ }_{13}$ Para un recuento del sistema de justicia penal juvenil alemán, en perspectiva comparada, véase ALBRECHT, Hans-Jörg, "Youth Justice in Germany", en Youth Crime and Youth Justice. Comparative and Cross-National Perspectives, Chicago-Londres: The University of Chicago Press, 2004, pp. 443-493; CANO PAÑOS, Miguel Ángel, El futuro del Derecho penal juvenil europeo. Un estudio comparado del Derecho penal juvenil en Alemania y España. Barcelona: Atelier, 2006, pp. 141-176; DÜNKEL, Frieder, Juvenil Justice in Germany, 2005, 42 pp., disponible en http://www.rsf.unigreifswald.de/fileadmin/mediapool/lehrstuehle/duenkel/JuvenileJustice.pdf [visitada el 16.04.2012].

${ }_{14}$ Para una revisión de la historia de la JGG alemana, SCHAFFSTEIN, Friedrich; BEULKE, Werner, Jugendstrafrecht, Eine systematische Darstellung, Stuttgart: Kohlhammer, $14^{\text {a }}$ edición, 2002, pp. 38 y ss.; CANO PAÑOS, El futuro, cit. nota n ${ }^{\circ} 13$, pp. 141 y ss. Tras aquella "Primera Ley de Reforma de la Ley de Tribunales Juveniles" (1. Gesetz zur Änderung des Jugendgerichtsgesetzes), de 1990, la JGG ha sido objeto tan sólo de modificaciones menores; de hecho, la "Segunda Ley de Reforma...", de 2008, muy lejos de las aspiraciones del proyecto original (sobre este proyecto, sintéticamente SCHAFFSTEIN / BEULKE, Jugendstrafrecht, cit. en esta misma nota $\mathrm{n}^{\circ} 14$, p. 43), apenas se limita a introducir una cláusula sobre la finalidad preventivo-especial de la aplicación de la JGG ("la aplicación del Derecho penal juvenil debe sobre todo prevenir nuevos hechos punibles por parte de un adolescente o un menor adulto. Para alcanzar ese fin, las consecuencias jurídicas y también el procedimiento - respetando el derecho de crianza que corresponde a los padres - deben orientarse primordialmente de conformidad con el principio educativo" - la traducción es nuestra -) y a regular unas pocas cuestiones relativas a la ejecución de las penas juveniles. 
Polít. crim. Vol. 7, N 13 (Julio 2012), Art. 1, pp. 1 - 73.

[http://www.politicacriminal.cl/Vol_07/n_13/Vol7N13A1.pdf]

Con anterioridad a la promulgación de la primera JGG, de 1923, los menores de 18 y mayores de 12 años de edad, tenían una imputabilidad condicionada, respondiendo sólo si se juzgaba que contaban con un nivel de comprensión suficiente para reconocer la punibilidad del hecho, caso en el cual se les aplicaba plenamente el régimen penal común, gozando de una atenuación de pena a partir de los marcos penales aplicados a los adultos. ${ }^{15}$

La nueva legislación, enmarcada dentro del movimiento de reforma que a nivel internacional promovió la creación de tribunales especiales para menores, orientados a la tutela y corrección de los infractores de ley penal, ${ }^{16}$ buscó sustituir la respuesta puramente punitiva por una inspirada en el "principio educativo" (Erziehungsgedangen), que confiere a la JGG el carácter de un derecho penal fundamentalmente preventivo-especial, sin renunciar, con todo, a la imposición de penas, ni a la prevención general (o a la retribución). ${ }^{17}$ De hecho, la JGG de 1923 distinguió dos formas de intervención alternativas, frente a los delitos cometidos por adolescentes: las medidas educativas (Erziehungsmaßregelen) y la pena juvenil (Jugendstrafe). La RJGG de 1943 introdujo una tercera forma de reacción: los medios disciplinarios (Zuchtmittel), que, con modificaciones, también conserva la JGG hasta la actualidad.

La pena juvenil, de naturaleza privativa de libertad, y cuya extensión máxima alcanza a los diez años, se reserva para casos en que las medidas educativas "no basten", y siempre que la "gravedad de la culpabilidad" del autor por el hecho, o sus "tendencias nocivas" hagan necesario recurrir a esa medida ( $\S 5.2$ y 17 de la JGG). Por su parte, las medidas educativas (que incluyen la imposición de "instrucciones" - como la de someterse a la orientación y supervisión de un adulto, compensar a la víctima, etc. - o de "asistencia educativa"), y los medios disciplinarios (salvo el arresto juvenil), en la actualidad son no privativos de libertad. ${ }^{18}$

También en materia procesal la JGG, desde 1923, considera reglas especiales, inspiradas en el "principio educativo". Fuera de la creación de órganos especializados - partiendo por los tribunales juveniles, pero incluyendo además, hoy en día, fiscales juveniles, y un servicio de Asistencia a los Tribunales Juveniles -, desde un principio, la JGG consideró diferencias con el proceso penal de adultos, al excluir la participación de público en el juicio oral y flexibilizar el principio de legalidad procesal, permitiendo terminar el proceso

\footnotetext{
${ }^{15}$ EISENBERG, Ulrich, Jugendgerichtsgesetz, Munich: Beck, $11^{\text {a }}$ edición, 2006, § 3 número marginal 3.

${ }^{16}$ SCHAFFSTEIN / BEULKE, Jugendstrafrecht, cit. nota $\mathrm{n}^{\circ} 14$, pp. 34 y ss. Críticamente, VO $\beta$, Michael: Jugend ohne Rechte. Die Entwicklung des Jugendstrafrechts, Frankfurt-New York: Campus Verlag, 1986, pp. 200 y ss.

${ }^{17}$ Sobre la vigencia de los fines preventivo-generales en la JGG, véase STROBEL, Sonia, Verhängung und Bemessung der Jugendstrafe - Eine Analyse unter besonderer Berücksichtigung der Strafzwecke. Aachen, Alemania: Shaker Verlag, 2006, pp. 11 y ss., 22, 12 y 53; sintéticamente, en relación con la pena privativa de libertad, COUSO, Jaime, "Límites a la imposición de sanciones privativas de libertad en el Artículo 26 de la Ley de Responsabilidad Penal del Adolescente", en AAVV, Estudios de derecho penal juvenil I, Santiago: Centro de Documentación, Defensoría Penal Pública, 2009, pp. 183 y ss.

18 Algunas instrucciones, como la de vivir con determinada familia o en un hogar (institucional), son ciertamente residenciales, pero su naturaleza jurídica no es privativa de libertad; más ambigua es la situación, en cambio, de la asistencia educativa en un hogar ( $\$ 12.2$ JGG), que, si se implementa en "hogares cerrados" (geschlossene Heimunterbringung), ya difícilmente puede considerarse no privativa de libertad; véase EISENBERG, Jugendgerichtsgesetz, cit. nota $\mathrm{n}^{\circ} 15, \S 12$ número marginal 42 y ss.
} 
DUCE, Mauricio; COUSO, Jaime. "El derecho a un juzgamiento especializado de los jóvenes infractores en el derecho comparado".

anticipadamente por razones de oportunidad; ${ }^{19}$ esta posibilidad, de la que dispone no sólo el fiscal ( $\$ 45 \mathrm{JGG})$, sino también el propio juez ( $\$ 47 \mathrm{JGG}$ ), fue enormemente reforzada por la reforma de la JGG de $1990 .^{20}$

Otras manifestaciones de la especialidad del estatuto legal del adolescente durante el proceso penal, contempladas en el texto (o desarrolladas por la aplicación práctica) de la JGG, se dan en materia de: ${ }^{21}$

- los límites a la actividad investigativa desarrollada por la policía y los fiscales

- la investigación sobre la personalidad y el entorno familiar y social del adolescente

- la declaración personal del adolescente imputado ante el juez, previa al juicio oral

- la orden de que el adolescente (y, en su caso, sus familiares y representante) se retiren de forma temporal de la sala, durante ciertas actuaciones el juicio oral que puedan ser perjudiciales para su educación

- exigencias específicas sobre el contenido de la fundamentación de la sentencia

- la reserva frente al adolescente condenado, de información relevante para la condena, pero perjudicial para su educación

- presencia de los padres o guardadores del adolescente acusado durante el juicio oral

- regulación especial del procedimiento simplificado

- restricción (ya no prohibición) ${ }^{22}$ a la facultades de la víctima para interponer querella

- restricción de los recursos disponibles para impugnar resoluciones judiciales

- medidas cautelares y presupuestos para la imposición de la prisión preventiva o internación provisoria

- ampliación de los casos de designación forzosa de un defensor

La JGG alemana, la más antigua de las legislaciones que contemplan un sistema de justicia penal juvenil - distinto de la justicia penal de adultos y de la legislación tutelar de menores - no está ajena a los debates surgidos en Europa y en otros continentes acerca de la conveniencia o no de endurecer la respuesta penal frente a la delincuencia juvenil, para

${ }^{19}$ EISENBERG, Jugendgerichtsgesetz, cit. nota $\mathrm{n}^{\circ} 15$, Einleitung número marginal 1.

${ }^{20}$ CANO PAÑOS, El futuro, cit. nota ${ }^{\circ} 13$, p. 169.

${ }^{21}$ Para un análisis crítico de estas manifestaciones del principio de especialidad, destacando ventajas y desventajas, véase ALBRECHT, Peter-Alexis, Jugendstrafrecht, Múnich: Beck, 3ª edición, 2000, pp. 357 y ss. (especialidad en el procedimiento previo), 367 y ss. (especialidad en el juicio oral), y 384 y ss. (especialidad en el régimen de recursos).

${ }^{22}$ De hecho, la prohibición de querella particular - tanto para delitos de acción privada como de acción pública - en la JGG fue una de las manifestaciones históricas de la especialidad del procedimiento penal de adolescentes, que se mantuvo intacta hasta que el año 2007 una reforma impulsada, entre otras, por organizaciones de apoyo a las víctimas, permitió su interposición en casos de delitos de acción pública en contra de la vida, la integridad corporal, la autodeterminación sexual y ciertos casos de graves delitos en contra de la libertad ambulatoria; véase al respecto HINZ, Werner, "Nebenklage im Verfahren gegen Jugendliche, Gedanken zum neuen $§ 80$ Abs. 3 JGG”, en Juristische Rundschau, n ${ }^{\circ} 4$ (2007), p. 140. Es interesante señalar, en todo caso, que, como lo recuerda el autor, si bien la prohibición respondía a una demanda histórica del movimiento por los tribunales de menores, no fue introducida a Alemania por la JGG de 1923, sino por la RJGG de los nazis, sin que quede claro si ello respondía a las demandas de aquel movimiento o si al "espíritu de un proceso penal totalitario", contrario a una víctima dotada de derechos propios (ibídem). 
Polít. crim. Vol. 7, N 13 (Julio 2012), Art. 1, pp. 1 - 73.

[http://www.politicacriminal.cl/Vol_07/n_13/Vol7N13A1.pdf]

acercarla más, en su caso, a la justicia penal de adultos, ${ }^{23}$ sin embargo, hasta ahora, se mantiene en lo esencial, como un sistema de justicia penal especial, con diferencias significativas en intensidad y cualidad de la respuesta penal, en comparación con el sistema penal de adulto, sin renunciar por ello a (la mayor parte de) las garantías básicas vigentes en éste. Las últimas reformas introducidas, con todo, manifiestan esta ambigüedad, entre especialidad $^{24}$ y rigor punitivo. ${ }^{25}$

\subsection{Costa Rica}

Durante los años 1994 y 1998 se creó en Costa Rica la Comisión Especial de Reformas Penales, con el objeto de actualizar y mejorar la legislación penal del país, ${ }^{26}$ respondiendo así a una serie de críticas presentes en diversos grupos sociales al sistema en general. En el ámbito de la adolescencia, esta reforma se materializó en la Ley de Justicia Penal Juvenil (LJPJ), del año 1996, la cual no sólo derogó la Ley Orgánica de la Jurisdicción Tutelar de Menores (1963) sino que marcó el término de la doctrina de la "situación irregular" para dar paso a la de "protección integral", estableciendo un modelo de responsabilidad que sincera y regula el tratamiento penal de los jóvenes. Se trató de uno de los primeros cambios en esta dirección emprendidos en Latinoamérica. Por estas razones se ha destacado que esta reforma "representó un avance significativo en la transformación de la justicia juvenil latinoamericana al abandonar la denominación de medidas para las consecuencias

\footnotetext{
${ }^{23}$ Véase, al respecto, DÜNKEL, Juvenil Justice, cit. nota $n^{\circ} 13$, pp. 35-36.

${ }^{24}$ Como en la reciente introducción (vigente desde el 1 de enero de 2008) de una referencia expresa al "principio educativo" en el $\S 2$ de la JGG, que declara la finalidad preventivo-especial de la aplicación de la ley, y obliga a orientar tanto las consecuencias jurídicas como el procedimiento de conformidad con de aquel principio; véase al respecto la referencia a la "Primera Ley de Reforma...", supra en nota ${ }^{\circ} 14$.

${ }^{25}$ Una manifestación de este tipo se aprecia en la reciente introducción (julio de 2008) de la custodia de seguridad posterior a la ejecución (nachträgliche Sicherungsverwahrung), siguiendo fielmente el modelo ofrecido pocos años antes por la legislación penal alemana de adultos, que, en 2004, introdujo la misma medida en el Código Penal alemán (véase VORMBAUM, Thomas, Einführung in die moderne Strafrechtsgeschichte, $2^{\text {a }}$ edición, Berlín-Heidelberg: Springer Verlag, 2011, p. 269, clasificando críticamente ambas reformas dentro de una tendencia neoconservadora dirigida al endurecimiento punitivo; sobre esta obra, véase MUÑOZ CONDE, Francisco, "Recensión: VORMABUM, Thomas. Einführung in die moderne Strafrechtsgeschichte (Introducción a la Moderna Historia del Derecho Penal)". Polít. crim. no 7, (2009), R17, pp. 1-16, en: http://www.politicacriminal.cl/n_07/r_1_7.pdf [visitado el 16.04.2012]. La custodia de seguridad (juvenil) posterior a la ejecución permite, una vez cumplida una pena juvenil de más de 7 años de duración, impuesta por determinados delitos graves, confinar al autor en un establecimiento de custodia de seguridad por tiempo indeterminado, cuando se den circunstancias de hecho que fundamenten una alta peligrosidad del condenado para la colectividad, de la que se desprenda a su vez una elevada probabilidad de que reitere delitos de esa naturaleza. Para más detalles, incluyendo la referencia al reciente pronunciamiento del Tribunal Europeo de Derechos Humanos, contrario a la aplicación retroactiva de la medida (y en contra, por tanto, de la autorización de tal aplicación retroactiva, por la Corte Suprema Federal alemana), véase COUSO, Jaime, "Sustitución y Remisión de Sanciones Penales de Adolescentes, Criterios y Límites para las Decisiones en Sede de Control Judicial de las Sanciones", en AAVV, Estudios de derecho penal juvenil II, Santiago: Centro de Documentación, Defensoría Penal Pública, 2011, p. 275, nota nº 10.

${ }^{26}$ TIFFER SOTOMAYOR, Carlos, "La Ley de Justicia Penal Juvenil dentro de los modelos teóricos de política criminal y fuentes legales", en: De la Arbitrariedad a la Justicia: adolescentes y Responsabilidad Penal en Costa Rica., Serie de Políticas \#5, San José: Unicef, 2000, p. 157.
} 
DUCE, Mauricio; COUSO, Jaime. "El derecho a un juzgamiento especializado de los jóvenes infractores en el derecho comparado".

jurídicas de la conducta infractora de la ley penal, y adoptar la denominación de sanciones". 27

Este modelo de responsabilidad busca dar una respuesta especial al adolescente que ha realizado hechos delictivos. En la exposición de motivos de la LJPJ se señala expresamente que el derecho penal juvenil costarricense ha adoptado una concepción punitivo-garantista, respetuoso de los derechos y garantías generales, pero que, al mismo tiempo, se hace cargo de la especial regulación que corresponde a los niños y jóvenes en todos los ámbitos de intervención -incluyendo la jurídica- ${ }^{28}$

Con el fin de enmarcarse en la regulación internacional sobre la niñez, la LJPJ limitó su ámbito de aplicación a niños y jóvenes entre doce y diecisiete años. Bajo esta edad, los niños no pueden ser objeto de persecución penal, estableciendo la ley una norma expresa al respecto (artículo 6 de la LJPJ). De la misma manera, la LJPJ buscó poner el acento de las diferencias entre la legislación penal juvenil y la adulta en cuanto a los fines perseguidos, señalando en su artículo 7 que la ley está orientada a la protección integral del menor, al respeto de su interés superior y demás derechos, y a que la aplicación de la ley está dirigida a la formación integral y a la reinserción del menor a la familia y a la sociedad. A este respecto, el artículo 44 agrega que el objetivo del proceso no es tan solo la determinación del hecho delictivo y la aplicación de la sanción correspondiente, sino que también la reincorporación del joven con su familia y, en general, en la sociedad. Por su parte, en el ámbito de la ejecución de las sanciones, se ha establecido una finalidad primordialmente educativa por sobre los preventivos generales, otorgando la flexibilidad necesaria para la consecución de dicho fin (Ver artículos 123 y 133).

En términos generales, la LJPJ fue capaz de incorporar los principios recogidos en los instrumentos internacionales que regulan el ámbito de la niñez, al adaptar las diversas instituciones del derecho penal y procesal de adultos a la especialidad requerida por este nuevo sistema, complementándolo además con nuevas figuras. De lo anterior se pueden dar como ejemplos la especialización de los actores, la flexibilización del proceso y la ampliación del catálogo de sanciones contempladas que permiten dar una respuesta más adecuada al adolescente. A este respecto se pueden distinguir tres tipos de sanciones: las socio-educativas, las de órdenes de orientación y supervisión y las sanciones privativas de libertad, estableciendo expresamente el carácter de última ratio que tiene esta última clase de sanción. ${ }^{29}$ Sobre este punto, un tema que ha sido polémico se refiere al elevado límite superior que contemplan las sanciones privativas de libertad o de internamiento, siendo éstas de diez años en el caso de los jóvenes entre 12 y 15 años y de quince años para los mayores.

Hasta la fecha, la LJPJ no ha sufrido grandes modificaciones. Las existentes no han estado exentas de la tendencia comparada a endurecer el tratamiento penal, que en el caso concreto

\footnotetext{
27 BELOFF, Mary, "Los nuevos sistema de justicia juvenil en América Latina (1989-2006)", Justicia y Derechos del Niño n ${ }^{\circ}$ 9, Santiago, 2007, p. 209.

${ }^{28}$ TIFFER SOTOMAYOR, Carlos, Ley de Justicia juvenil, $2^{\circ}$ Edición, San José: Juristexto, 2004. p. 244

${ }^{29}$ TIFFER SOTOMAYOR, cit. nota ${ }^{\circ} 28$, p. 118 y ss.
} 
Polít. crim. Vol. 7, N 13 (Julio 2012), Art. 1, pp. 1 - 73.

[http://www.politicacriminal.cl/Vol_07/n_13/Vol7N13A1.pdf]

de la LJPJ se llevó a cabo a través de la Ley de Ejecución de Sanciones Penales Juveniles la que amplió la duración de la sanciones de menor intensidad. ${ }^{30}$

\subsection{España}

La Ley Orgánica 5/2000, de 12 enero de 2000, reguladora de la responsabilidad penal de los menores, es el principal esfuerzo de la legislación española para regular de forma completa el ámbito penal de los niños y jóvenes, a la luz los principios de la Convención de los Derechos del Niño. ${ }^{31}$ Sin embargo, los cambios hacia un sistema de responsabilidad habían comenzado a gestarse casi una década antes, proceso en el cual es posible identificar diversos hitos. ${ }^{32}$ En primer lugar, la sentencia del Pleno del Tribunal Constitucional, $36 / 1991$, de 14 de febrero de $1991{ }^{33}$ que declaró inconstitucional el artículo 15 de la antigua Ley de Tribunales Tutelares de Menores. Dicho artículo disponía expresamente que los procedimientos dirigidos a corregir a los menores no se sometieran a las reglas procesales vigentes, en manifiesta contradicción con los principios de seguridad jurídica e igualdad consagrados en la Constitución española. La antigua ley de menores era tributaria de la doctrina de la "situación irregular" y ella entraba en conflicto con disposiciones constitucionales básicas reconocidas en favor de todas las personas. ${ }^{34}$

Producto del fallo del TC, de las solicitudes emanadas del propio Poder Judicial y de la opinión de un importante sector de la comunidad legal, se dictó la Ley Orgánica 4/1992, de 5 de junio de 1992, que reformó y modificó la Ley de Tribunales de Menores de 1985, con el fin de regular un procedimiento propio para los jóvenes que hubiesen cometido infracciones a la ley penal, lo que constituyó el segundo hito en el establecimiento de un sistema basado en los principios de la Convención. Con todo, se trató de una reforma de carácter parcial. En ella sólo pueden identificarse algunos rasgos de especialidad exigidos por la legislación internacional, por ejemplo, se estableció un principio de oportunidad más amplio que el de adultos, sanciones especiales y el refuerzo de algunas de las garantías a

${ }^{30}$ Artículo 111. - Reformas. Refórmase la Ley $\mathrm{N}^{\circ}$ 7576, en las siguientes disposiciones: a) En el artículo 125, se sustituye la frase "dos años", por la frase "cinco años". b) En el último párrafo del artículo 129, se sustituye la frase "no será mayor de un año", por la frase "no será mayor de tres años". c) El primer párrafo del artículo 130, se sustituye la frase "no podrá exceder de un año", por la frase "no podrá exceder de tres años". d) En el artículo 140, se sustituye la frase "deberá ser trasladado" por la frase "podrá según corresponda ser trasladado".

${ }^{31}$ Apartado 2 de la Exposición de Motivos de la LORPM: "Dado que la expresada Ley Orgánica se reconocía a sí misma expresamente el carácter de una reforma urgente, que adelanta parte de una renovada legislación sobre reforma de menores, que será objeto de medidas legislativas posteriores, es evidente la oportunidad de la presente Ley Orgánica, que constituye esa necesaria reforma legislativa, partiendo de los principios básicos que ya guiaron la redacción de aquélla (especialmente, el principio del superior interés del menor), de las garantías de nuestro ordenamiento constitucional, y de las normas de Derecho internacional, con particular atención a la citada Convención de los Derechos del Niño de 20 de noviembre de 1989, y esperando responder de este modo a las expectativas creadas en la sociedad española, por razones en parte coyunturales y en parte permanentes, sobre este tema concreto"

${ }^{32}$ Ver en ORNOSA FERNÁNDEZ, María Rosario, Derecho Penal de Menores, $4^{\mathrm{a}}$ edición, Barcelona: Bosch, 2007 , pp. 57 y ss.

${ }^{33}$ ORNOSA FERNÁNDEZ, Derecho Penal de Menores, cit. nota n ${ }^{\circ}$ 32, p. 57

${ }^{34}$ En este sentido véase CANO PAÑOS, El futuro, cit. nota $n^{\circ} 13$, p. 178 y 179. En este texto puede encontrarse además un buen resumen de la historia y evolución del sistema español con anterioridad a la LO 5/2000 en páginas 176 a 184 . 
DUCE, Mauricio; COUSO, Jaime. "El derecho a un juzgamiento especializado de los jóvenes infractores en el derecho comparado".

nivel procesal. No obstante, el carácter urgente y parcial de esta reforma se tradujo en una serie de vacíos, que finalmente pretendieron ser resueltos con la promulgación de la Ley Orgánica 5/2000. Al respecto, E. Fernández señala que la Ley "permitió saldar la deuda que el legislador había adquirido con la jurisdicción de menores, siendo su objetivo fundamental consolidar legislativamente el modelo de responsabilidad, que en la práctica se venía aplicando hace muchos años". 35

El objetivo de la LO 5/2000 es dar una respuesta especial de carácter educativo a los jóvenes que han realizado conductas delictivas, por lo mismo declara su rechazo a los fines retributivo o de prevención general del derecho penal de adultos. ${ }^{36}$ Sin embargo, tal como expresa Fernández, ${ }^{37}$ la exposición de motivos no se condice con el tratamiento que da la Ley a cierto tipo de delitos -lo más graves o donde exista reincidencia-, cuya regulación contiene una marcada tendencia preventiva general, especialmente después de la serie de reformas que ha sufrido la ley desde su proyecto original hasta la fecha. Desde estos fines se ha debido estructurar el sistema de responsabilidad de menores español, buscando, por una parte, crear un sistema especializado en concordancia con los principios básicos derivados de la regulación internacional de los derechos del niño, y por otra, la necesidad social de sancionar penalmente los hechos delictivos cometidos por jóvenes, adaptando el sistema punitivo a su especial condición.

La LO 5/2000 se aplica en principio a niños y jóvenes mayores de 14 y menores de 18 años, distinguiéndose para efectos de la graduación de las consecuencias de su actuar dos tramos: entre mayores de 14 y menores de 16 y entre mayores de 16 y menores 18 años (artículo $1^{\circ}$ ). Además, se admite bajo ciertos supuestos (establecidos en el artículo $\left.4^{\circ}\right)^{38}$ que la ley sea aplicada a mayores de 18 años y menores de 21 años. Como características más relevantes de este sistema se pueden mencionar las siguientes: el procedimiento aplicable a los menores está inspirado en el abreviado de adultos, contemplado en la Ley de Enjuiciamiento criminal; ${ }^{39}$ existe una separación de las funciones de instruir y enjuiciar, a cargo respectivamente, de un Fiscal y un Juez especializado; ${ }^{40}$ se otorga al MP un amplio principio de oportunidad -solo limitado si los hechos pueden ser constitutivos de un delito grave o donde existe violencia o intimidación, o si el joven es reincidente-; prevalece el principio acusatorio; la medida de internación tiene carácter excepcional, contemplando un conjunto de medidas alternativas a la privación de libertad fundadas en el fin educativo; se consagra el derecho a defensa desde la incoación del expediente; se admite la mediación como forma de resolución de conflicto; se contempla un recurso de casación especial del

\footnotetext{
${ }^{35}$ FERNÁNDEZ MOLINA, Esther, Entre la educación y el castigo, Valencia: Tirant Lo Blanch, 2008, p.142

${ }^{36}$ Ibíd. p. 150.

${ }^{37}$ Ibíd. p. 150 y ss.

${ }^{38}$ En lo central se exige que el delito cometido sea menos grave y sin violencia e intimidación, que el joven no haya sido condenado por sentencia firme por un hecho cometido una vez que cumplió los 18 años y que el grado de madurez del mismo aconseje el uso de la LO 5/2000. Con mayor detalle véase artículo $4^{\circ}$ LO $5 / 2000$.

${ }^{39}$ ORNOSA FERNÁNDEZ, Derecho, cit. nota n³2, p. 99

${ }^{40}$ Hay que recordar que el sistema procesal penal de adultos en España aún mantiene el sistema de juez de instrucción responsable tanto de conducir la investigación como de controlar el respecto de las garantías individuales en la misma. De esta forma, la LO 5/2000 establece una estructura más similar con el tipo de organización del sistema procesal penal vigente en nuestro país y en la casi totalidad de América Latina.
} 
Polít. crim. Vol. 7, N 13 (Julio 2012), Art. 1, pp. 1 - 73.

[http://www.politicacriminal.cl/Vol_07/n_13/Vol7N13A1.pdf]

sistema; y se establece la necesaria especialización de todos aquellos que tenga relación con el menor durante el proceso. ${ }^{41}$

Desde antes de la entrada en vigencia de la LO 5/2000 ésta ha sido constantemente modificada. Se puede mencionar así la Ley Orgánica 7/2000, de 22 de diciembre de 2000, en relación a los delitos de terrorismo; la Ley Orgánica 9/2000, de 22 de diciembre de 2000 sobre medidas urgentes para la agilización de la Administración de la Justicia, que suprimió las Salas de Menores de los Tribunales Superiores de Justicia y dilató la entrada en vigencia de la aplicación de la LO 5/2000 a los jóvenes entre 18 y 21 años; Ley Orgánica 9/2002, de 10 de diciembre de 2002, que modificó el Código Penal y el Código Civil en materia de sustracción de menores, y que nuevamente postergó la aplicación de la Ley hasta el año 2007 a los jóvenes entre 18 y 21 años; y, la Ley Orgánica 15/2003, de 25 de noviembre de 2003, que estableció acusación particular sin límites en el procedimiento de menores.

Sin duda, la reforma de mayor relevancia es la que realizó la Ley Orgánica 8/2006, de 4 de diciembre de 2006, la cual modificó alrededor de la mitad de los artículos de la LO 5/2000, y tuvo como objetivo principal endurecer el tratamiento penal a los adolescente infractores (por ejemplo en el tipo de consecuencias posibles frente a la comisión de delitos y en el uso del internamiento provisorio). Según el mensaje, este endurecimiento se justifica debido a que "las estadísticas revelan un aumento considerable de delitos cometidos por menores, los que han causado gran preocupación social y ha contribuido a desgastar la credibilidad de la ley por la sensación de impunidad de las infracciones más cotidianas y frecuentemente cometidas por estos menores, como son los delitos y faltas patrimoniales". Se trató de una reforma que ha generado mucha polémica en la doctrina española tanto respecto a su contenido como al supuesto fáctico en el que se fundó. ${ }^{42}$

\subsection{Estados Unidos de Norteamérica ${ }^{43}$}

El sistema de justicia juvenil de los Estados Unidos representa un caso un tanto diverso respecto a Costa Rica y España. Hemos visto que en ellos los actuales sistemas de justicia juvenil corresponden a reformas significativas implementadas en las últimas décadas con el propósito explícito de establecer sistemas de responsabilidad especializados compatibles con las normas internacionales sobre la materia. Así, estos nuevos sistemas de responsabilidad penal juvenil se han construido a partir de una reforma legislativa que ha pretendido realizar un cambio de paradigma radical respecto a los sistemas tutelares vigentes en dichos países en forma previa. En los Estados Unidos, en cambio, se puede apreciar que el actual sistema corresponde más bien la evolución que ha experimentado la justicia juvenil especializada desde su establecimiento a principios del siglo XX. En alguna medida esto lo acerca más al desarrollo que el sistema experimentó en Alemania según ya tuvimos oportunidad de revisar.

\footnotetext{
${ }^{41}$ ORNOSA FERNÁNDEZ, Derecho, cit. nota n ${ }^{\circ} 32$, pp. 99, 114 y ss.

${ }^{42}$ Véase ORNOSA FERNÁNDEZ, Derecho, cit. nota ${ }^{\circ} 32$, pp. 145-154.

${ }^{43}$ Sobre el desarrollo de la justicia juvenil en los Estados Unidos la literatura es amplísima; por su claridad y sencillez, se recomienda revisar GARDNER, Martin, Understanding Juvenile Law, New York: Mathew Bender, 1997, pp. 179-198.
} 
DUCE, Mauricio; COUSO, Jaime. "El derecho a un juzgamiento especializado de los jóvenes infractores en el derecho comparado".

Hasta antes del surgimiento de las cortes juveniles especializadas (cuyo hito inicial fue el establecimiento de la corte juvenil especializada en el Estado de Illinois en 1899 por medio de la Illinois Juvenile Court Act del mismo año) ${ }^{44}$ la persecución penal de los jóvenes estuvo entregada fundamentalmente a los sistemas de adultos. Con el surgimiento de los nuevos sistemas especializados durante el siglo XX, estos tuvieron a cargo el conocimiento de las infracciones juveniles. La filosofía central que ánimo dicho sistema fue la de considerar que los jóvenes no podían ser penalmente responsables por los delitos que hubieren cometido y, por tanto, el objetivo central del sistema era buscar la ayuda y rehabilitación de los jóvenes infractores. ${ }^{45} \mathrm{El}$ paradigma instalado fue, en consecuencia, el tutelar o de la "situación irregular".

Hasta la segunda mitad del siglo XX los diversos sistemas de justicia juvenil en los Estados Unidos no fueron objeto de supervisión constitucional de parte de la Corte Suprema Federal, lo que les entregó en la práctica un margen amplio de discrecionalidad a los Estados para regular de manera bastante flexible la organización de los procesos juveniles. En su mayoría esa regulación reflejó la ideología tutelar instalada desde el nacimiento del sistema, lo que se tradujo en un escaso reconocimiento de garantías constitucionales en favor de los jóvenes imputados $\mathrm{y}$, por otra parte, la conceptualización del proceso por infracciones juveniles como un proceso de carácter civil y no penal. ${ }^{46}$ Con todo, a partir de la década de los sesenta una serie de decisiones de la Corte Suprema cambiaron completamente el panorama. El caso más relevante y paradigmático fue la decisión de la Corte Suprema en In Re Gault $1967,{ }^{47}$ por medio de la cual la Corte reconoció que los jóvenes eran titulares de un conjunto de derechos básicos del debido proceso reconocidos también en favor de adultos en la Constitución, indicando que la falta de estas protecciones procesales en las cortes juveniles había derivado en "arbitrariedad". Según el fallo, la Corte estimaba que ser menor de edad no habilitaba a tener un "Kangaroo Court", poniéndose de manifiesto la necesidad de resguardar mínimas garantías. ${ }^{48}$ Con todo, al mismo tiempo, la Corte Suprema reconoce que los derechos en favor de los jóvenes no son exactamente los mismos que los que disponen los adultos. Es así como en una serie de fallos posteriores, la propia Corte Suprema tuvo la posibilidad de ir precisando los alcances de los derechos del debido proceso en favor de jóvenes, en algunos casos ampliando la aplicación de garantías procesales mencionadas originalmente en Gault y, en otros, estableciendo límites a las mismas. $^{49}$

\footnotetext{
${ }^{44}$ Véase SHEPHERD, Robert, "Still Seeking the Promise of Gault: Juveniles and the Right to Counsel", Criminal Justice Magazine, vol. $18 \quad \mathrm{n}^{\mathrm{O}} 22003$, en: http://www.americanbar.org/tools/digitalassetabstract.html/content/dam/aba/publishing/criminal_justice_mag azine/crimjust_mo_premium_cr_cjmag_18_2_promiseofgault.pdf [visitado el 16.04.2012].

${ }^{45}$ GARDNER, Understanding, cit. nota ${ }^{\circ}$ 43, p. 183.

${ }^{46}$ Idem, p. 184.

${ }^{47} 387$ U.S 1 (1967).

${ }^{48}$ Véase KRISBERG, Barry, "Rediscovering the Juvenile Justice Ideal in the United States", en Comparative Youth Justice, London: Sage, 2006, p. 7

${ }^{49}$ En ampliación de derechos se encuentra por ejemplo el fallo en el caso In Re Winship (397 U.S. 358, 1970) que hace extensivo el estándar de convicción "Beyond reasonable doubt" a los jóvenes. En el lado de establecimiento de límites puede verse el caso McKeiver v. Pennsylvania (403 U.S. 528, 1971) en el cual se estableció que la garantía de juicio por jurados no se extendía a las audiencias de juicio de los jóvenes.
} 
Polit. crim. Vol. 7, No 13 (Julio 2012), Art. 1, pp. 1 - 73.

[http://www.politicacriminal.cl/Vol_07/n_13/Vol7N13A1.pdf]

Más allá de la precisión de los contornos de las garantías aplicables, las decisiones de la Corte Suprema, en especial en Gault, produjeron un impacto significativo en las legislaciones a nivel estatal que se vieron obligadas a cambiar la orientación de sistemas preponderantemente basados en la ideología tutelar a sistemas pensados desde la lógica de las garantías individuales. No obstante esto, como todo proceso de evolución gradual, no se ha tratado de un cambio absoluto o radical de sistema, por lo que es posible apreciar que en la actualidad, como veremos en los próximos capítulos, en los distintos sistemas de justicia juvenil en los Estados Unidos todavía conviven -con niveles de tensión importantessistemas inspirados tanto por la lógica tutelar como por la lógica de las garantías. Esta variedad es consecuencia, también, del sistema federal que permite que cada Estado tenga autonomía para regular normativamente los procesos de responsabilidad juvenil. ${ }^{50}$

Debido a la diversidad de regulaciones es difícil explicar un modelo detalladamente en el caso de los Estados Unidos, por eso sólo mencionaremos algunos principios fundamentales de carácter muy general sobre los que se estructuran los sistemas de justicia juvenil en dicho país. Un primer elemento que hay que considerar es que la competencia que disponen las cortes juveniles especializadas normalmente abarca dos tipos de conductas. Por una parte están los casos de "delinquency", que corresponden a comportamientos o conductas que, cometidos por adultos, darían lugar a una persecución penal por un delito. De otra parte, también conocen las denominadas "status offenses" que incluyen un conjunto de conductas prohibidas a los niños y jóvenes, como por ejemplo el ausentismo escolar y abandono del hogar, debido a las especiales necesidades de atención y cuidado requeridos por los menores de edad. Como se puede apreciar, se trata de comportamientos muy diversos en los cuales el sistema debiera presentar diferencias. Para los efectos de nuestro trabajo nos centraremos en el análisis de las reglas que regulan los procesos por el primer tipo de conductas y no los "status offenses" ya que ellas son comparables con el resto de los sistemas objeto de nuestro estudio.

Respecto a las edades mínimas y máximas existen bastantes diferencias. Lo más usual es que el límite de edad máximo sea los 18 años, aún cuando existen jurisdicciones que ponen el límite un poco más bajo (17 o 16 años). En cuanto a la edad mínima, no obstante también presentarse diferencias relevantes entre Estados, muchos de ellos siguen la regla tradicional del Common Law que fija el mínimo en siete años. ${ }^{51}$ Una característica muy importante es que los jóvenes que quedan sometidos a la jurisdicción juvenil especializada no tienen "derecho" a ser juzgados necesariamente por estos tribunales especializados. En casi todos los Estados se admite, en al menos algunas hipótesis, que un caso de "delinquency" sea conocido por las cortes de adultos, para lo cual debe hacerse una transferencia de jurisdicción (Waivers of Jurisdiction). La forma más común de hacer la transferencia es por

\footnotetext{
50 Junto con la legislación de cada Estado existe una normativa federal denominada Federal Juvenile Delinquency Act (18 U.S.C.A) (en delante FJDA) cuyo objetivo es remover del proceso penal ordinario a jóvenes que, en caso de haber sido adultos, habrían cometido un delito federal que hubiera quedado sometido a dicha jurisdicción. El objetivo de fondo de esta legislación es entregarle a los jóvenes infractores una posibilidad de rehabilitación más que castigo basado en la creencia que los jóvenes tienen, por encontrarse en un proceso formativo, muchas más posibilidades de rehabilitarse que un adulto. Véase, RADLER, Jean, "Treatment Under Federal Delinquency Act (18 U.S.C.A 5031-5042) of Juvenile Alleged to Have Violated Law of United States", en American Law Reports Federal, no 137 (1997), párrafo 2(a).

${ }^{51}$ Véase GARDNER, Understanding, cit. nota ${ }^{\circ}$ 43, pp. 200-204.
} 
DUCE, Mauricio; COUSO, Jaime. "El derecho a un juzgamiento especializado de los jóvenes infractores en el derecho comparado".

decisión judicial de la corte juvenil la cual, previa evaluación del caso y del joven imputado, puede decidir que este se quede en el sistema juvenil o sea enviado al sistema ordinario de adultos. Los criterios para la transferencia son muy variables entre las jurisdicciones pero en general entregan un marco importante de discrecionalidad a los jueces para la decisión. $^{52}$

En materia de estructura procesal, el procedimiento para conocer de las conductas de "delinquency" se estructura sobre bases similares al del proceso de adultos por infracciones de carácter penal. En general, se trata de un procedimiento de rasgos adversariales y con reconocimiento de garantías básicas del debido proceso (como ya hemos visto como consecuencia de Gault y la jurisprudencia posterior). En los próximos capítulos tendremos oportunidad de ver con detalle algunas regulaciones específicas, con todo, si interesa señalar que sigue definiéndose no como un proceso penal, aún cuando se reconozca sus similitudes, no lo es y eso justifica que el reconocimiento de garantías haya sido limitado hasta el momento.

\section{Primer Eje: Estrategias de Reforzamiento del Debido Proceso en el Derecho Comparado}

Un primer eje temático en donde el principio de especialidad tiene un impacto relevante en materia procesal penal es en el reforzamiento de ciertas garantías que integran al debido proceso. Esta idea de reforzamiento se refleja con mucha claridad en la LJPJ de Costa Rica, la que en su capítulo II -referido a los derechos y garantías fundamentales- señala en su artículo 10 que desde el inicio de la investigación policial y durante el desarrollo de todo el proceso a los jóvenes se les deben respetar las garantías procesales básicas para el juzgamiento de adultos pero "además, las que correspondan por su condición especial". 53 Cabe señalar, además, que dentro de las garantías procesales básicas se consideran no sólo aquellas desarrolladas en la legislación interna (constitucional y legal) sino que todas aquellas consagradas en los tratados internacionales de derechos humanos.

Como veíamos en el trabajo que sirve de base a esta investigación, ${ }^{54}$ un análisis más específico de los instrumentos del sistema internacional lleva a concluir que los principales aspectos en donde el principio de especialidad se traduce en diferencias significativas de reforzamiento o ampliación de garantías del debido proceso son cuatro: El fortalecimiento de la libertad y las mayores restricciones a su privación en el proceso; exigencias más estrictas respecto a la extensión temporal del proceso; mayores resguardos al derecho de defensa (en diversas manifestaciones); y, exigencias más estrictas para la renuncia de derechos del debido proceso. A continuación revisaremos la manera en que cada uno de estos cuatro temas ha sido consagrada a nivel normativo y luego desarrollada jurisprudencialmente en los países objeto de nuestra investigación.

\footnotetext{
${ }^{52}$ GARDNER, Understanding, cit. nota $\mathrm{n}^{\circ} 43$, pp. 207-209.

${ }^{53}$ Un comentario sobre esta disposición y sus alcances puede verse en TIFFER, Carlos, Ley de Justicia Penal Juvenil, San José: Editorial Juritexto, 2004, pp. 51-52.

${ }^{54}$ DUCE, cit. nota $n^{\circ} 1$, pp. 82 y ss.
} 
Polít. crim. Vol. 7, N 13 (Julio 2012), Art. 1, pp. 1 - 73.

[http://www.politicacriminal.cl/Vol_07/n_13/Vol7N13A1.pdf]

\subsection{Fortalecimiento de la Libertad y Mayores Restricciones a su Privación en el Proceso}

La privación de libertad en el proceso a la espera de una decisión definitiva constituye una de las afectaciones más significativas a los derechos de las personas objeto de una investigación criminal y, por lo mismo, es objeto de preocupación especial en la legislación internacional de derechos humanos y comparada tanto tratándose de adultos como jóvenes. Ya tuvimos oportunidad de señalar en otro trabajo que esto se ha reflejado con particular intensidad en la legislación internacional juvenil. ${ }^{55}$ El punto que justifica esta preocupación es que los niños y jóvenes, por su estado de desarrollo, se encuentran en una situación de vulnerabilidad mayor que los adultos que hace que los efectos negativos de la privación de libertad sean más profundos y tengan consecuencias que se extiendan por un período más largo. ${ }^{56}$ Estas exigencias más altas se traducen en las mayores restricciones a la procedencia de esta medida, a su duración temporal y a las condiciones de su cumplimiento, que ya se tuvo oportunidad de analizar en el mismo trabajo.

Las ideas descritas se encuentran recogidas en las cuatro legislaciones revisadas. En general, en todas ellas se asume con claridad que la privación de libertad de los jóvenes imputados debiera ser una medida de excepcionalidad y restringida a casos específicos. De esta manera se refuerza la idea que el derecho central de una persona objeto de un proceso es su libertad. Con todo, la forma en que se articulan estos principios a nivel legislativo, y el cómo ellos son aplicados por los tribunales, presentan diferencias en algunos casos importantes, de tal manera que a menudo las prácticas desarrolladas a nivel interno no se diferencien mucho, a favor de los jóvenes, de las que se mantienen con imputados mayores de edad.

A continuación revisaremos cómo estos elementos han sido reconocidos en los cuatro países que constituyen objeto de nuestro estudio.

\subsubsection{Procedencia de la Prisión Preventiva}

Como ya señalábamos, la regla general en los países objeto de nuestra observación es la definición básica de que la prisión preventiva constituye una medida cautelar excepcional tratándose de jóvenes imputados por infracciones penales.

Un buen ejemplo de lo anterior lo constituye el caso de la JGG alemana, que en materia de presupuestos para la imposición de la prisión preventiva (Untersuchungshaft) contempla a

\footnotetext{
${ }^{55}$ DUCE, cit. nota $n^{\circ} 1$, pp. 85-86.

${ }^{56}$ En el caso de los Estados Unidos puede verse en este mismo sentido a SHEPHERD, Robert, "Speedy Trials for Juveniles", Criminal Justice Magazine vol. $4 \quad \mathrm{n}^{\mathrm{o}} 4 \quad$ (2000), en: http://www.americanbar.org/publications/criminal_justice_magazine_home/crimjust_mo_premium_cr_cjmag _17_1_juvenile.html [visitado el 16.04.2012]. En Costa Rica esta idea ha sido recogida por la jurisprudencia de la Sala Constitucional de la Corte Suprema que ha señalado "Los niños y adolescentes, por encontrarse en una etapa decisiva en la formación de su personalidad, pueden resultar aún más severamente lesionados con el encierro y desde esa óptica, la prisión o detención como medida cautelar ha de tener un carácter excepcionalísimo y ha de hacerse uso de ella únicamente en los casos en que se considere indispensable y por el período de tiempo más breve que proceda" Resolución 4836-99 de 22 de junio de 1999, párrafo III. Véase también Voto $n^{\mathrm{o}} 7227-05$ de 9 de julio de 2005 en donde se repite la misma idea.
} 
DUCE, Mauricio; COUSO, Jaime. "El derecho a un juzgamiento especializado de los jóvenes infractores en el derecho comparado".

lo menos tres diferencias explícitas con la regulación que sobre la materia contiene la legislación procesal penal de adultos (la "Ordenanza Procesal Penal”, en adelante StPO - su sigla alemana -): $1^{\text {a }}$, la consagración expresa de una cláusula de subsidiariedad de la prisión preventiva respecto de a otras medidas educativas o cautelares; $2^{\mathrm{a}}$, una regulación especial del principio de proporcionalidad, en lo que atañe a la necesaria consideración de los perjuicios que la ejecución de la prisión preventiva podría acarrear al adolescente; y $3^{\mathrm{a}}$, una restricción, respecto de los menores de 16 años, de la procedencia de la prisión preventiva fundada en el peligro de fuga.

Esas restricciones se añaden a las que ya contempla la regulación común de la prisión preventiva en la StPO, conforme a la cual, esta medida cautelar sólo procede si, existiendo una "fundada sospecha" (dringender Verdacht) de que el imputado ha cometido un delito, se da alguno de los presupuestos o motivos que legalmente pueden fundamentar el recurso a la prisión (Haftgrund): fuga u ocultamiento del imputado; peligro de fuga; peligro de ocultamiento o destrucción de evidencias probatorias; especial gravedad del delito imputado (asesinato, homicidio, formación de una organización terrorista, incendio, detonación de bombas, etc.); y, peligro de reiteración de determinados delitos ${ }^{57}$. En todos esos casos, además, la prisión preventiva no debe ser desproporcionada en relación con la gravedad del asunto y la pena esperada. ${ }^{58}$

Volviendo ahora al reforzamiento del carácter excepcional de esta medida en la legislación especial para adolescentes, su primera manifestación es la cláusula de subsidiariedad, contemplada en el $\S 72$ de la JGG -y que la StPO, en cambio, desconoce para los adultos-, conforme a la cual "la prisión preventiva sólo puede ser impuesta y ejecutada cuando su finalidad no pueda ser alcanzada a través de una disposición provisoria sobre la educación o a través de otras medidas". ${ }^{59}$ Las medidas educativas pueden consistir en un "acompañamiento educativo" o la acogida del adolescente en un hogar comunitario o en una familia u hogar institucional, así como la asignación o cambio de una plaza laboral o de capacitación profesional, el alejamiento del adolescente de un grupo que se considera una influencia negativa para él, etc. ${ }^{60}$ Las "otras medidas" podrían consistir en un compromiso de palabra asumido por el joven ante el juez (respecto de su conducta), la imposición de determinados deberes de presentarse ante, o de reunirse con, personas de confianza del joven o del tribunal. ${ }^{61}$ Para promover la efectiva consideración de estas alternativas, los $\S \S$ 72 a y 72 b de la JGG disponen que debe informarse de la detención y, en su caso, de la orden de prisión preventiva de un adolescente, al servicio de Asistencia a los Tribunales Juveniles (Jugendgerichtshilfe), al que se permitirá comunicarse con el adolescente con la misma facilidad que a su abogado, con el objetivo de que este servicio cumpla con la trascendental misión de investigar - o contribuir a crear - las condiciones que permitirían evitar la prisión preventiva y recurrir, en cambio, a una medida alternativa. ${ }^{62}$ Sin embargo, conforme a la advertencia de Hans-Jörg Albrecht, este objetivo de evitación de la prisión

${ }_{58}^{57}$ LAUBENTHAL / BAIER, Jugendstrafrecht. cit. nota ${ }^{\circ}$ 11, p. 123.

${ }^{58}$ Ibíd., p. 124.

${ }^{59} \mathrm{La}$ traducción es nuestra.

${ }^{60}$ EISENBERG, Jugendgerichtsgesetz, cit. nota $\mathrm{n}^{\circ} 15, \S 71$ número marginal 5.

${ }^{61}$ EISENBERG, Jugendgerichtsgesetz, cit. nota $\mathrm{n}^{\circ} 15, \S 72$ número marginal $3 \mathrm{a}$.

${ }^{62}$ LAUBENTHAL / BAIER, Jugendstrafrecht. cit. nota ${ }^{\circ}$ 11, p. 126. 
Polit. crim. Vol. 7, No 13 (Julio 2012), Art. 1, pp. 1 - 73.

[http://www.politicacriminal.cl/Vol_07/n_13/Vol7N13A1.pdf]

preventiva, a través de las medidas introducidas por la reforma a la JGG de 1990, no habría dado los resultados esperados, especialmente respecto de adolescentes de familias inmigrantes, que representan la mayoría de los imputados de esa edad sometidos a dicha medida cautelar. ${ }^{63}$

Por lo que respecta a la regulación especial del principio de proporcionalidad, a las exigencias ya establecidas por la regulación procesal penal común - conforme a la cual, como se vio, la imposición de la prisión preventiva no debe ser desproporcionada en relación con la gravedad del asunto y la pena esperada -, el $\S 72$ de la JGG exige al juez "considerar los especiales costos de la ejecución para los adolescentes" y explicitar en la resolución respectiva las razones que le llevan a concluir que las demás medidas disponibles (en particular, la acogida provisoria del adolescente en un hogar del servicio de Asistencia a la Juventud) no son suficientes y que la prisión preventiva no es desproporcionada, lo que viene a configurar un "especial deber de fundamentación". ${ }^{64} \mathrm{La}$ exigencia de que se tomen en cuenta, al realizar el juicio de proporcionalidad, los "especiales costos" de la prisión preventiva para el adolescente, se entiende en el sentido de poner en la balanza los perjuicios psíquicos causados por la medida (cuya realidad, para el Consejo Federal alemán, está "fuera de toda discusión"), así como sus efectos negativos en los ámbitos social, educacional y laboral - teniendo en cuenta que, en Alemania, un 50\% de los adolescentes o jóvenes adultos que tenían un puesto de trabajo o estaban matriculadas en la enseñanza formal al momento de entrar en prisión preventiva, no la recuperaron al quedar en libertad -, e incluso otros elementos, como el elevado peligro de suicidio. ${ }^{65}$ Sin embargo, el respeto efectivo del principio de proporcionalidad, en lo que respecta a la consideración de la pena esperada, es muy limitado, si se tiene en cuenta el elevado porcentaje de casos (cercano al $50 \%$ ) en los que, habiéndose decretado previamente la prisión preventiva, el imputado finalmente no fue condenado a una pena privativa de libertad efectiva, ${ }^{66}$ proporción muy similar a la que se presenta entre imputados mayores de edad. ${ }^{67}$ Además, se cuestiona el eventual efecto de prejuzgamiento (como "profecía auto cumplida") que el cálculo de la pena probable, para los efectos del juicio de proporcionalidad de la prisión preventiva, puede producir en un juez que posteriormente podría terminar decidiendo e individualizando efectivamente la pena a imponer. ${ }^{68}$

Por último, en lo que atañe a la regulación restrictiva que favorece a los menores de 16 años, para la aplicación de la prisión preventiva fundada en el "peligro de fuga", de conformidad con el $\S 72$, párrafo 2 , de la JGG, esta causal sólo tiene aplicación si el imputado " $1^{\circ}$ ya se ha sustraído al proceso o ha dado muestras de querer hacerlo, o; $2^{\circ}$ no cuenta con domicilio o lugar de residencia dentro del territorio en el que esta ley tiene

\footnotetext{
${ }^{63}$ ALBRECHT, Hans-Jörg, Ist das deutsche Jugendstrafrecht noch zeitgemäß?, Munich: Beck, , 2002, p. D 130.

${ }^{64}$ Deber que, sin embargo, como advierte ALBRECHT, Ist das deutsche Jugendstrafrecht...?, cit. nota $\mathrm{n}^{\circ}$ 63, p. 130, "es ostensible que no se cumple en una medida suficiente".

${ }^{65}$ EISENBERG, Jugendgerichtsgesetz, cit. nota $\mathrm{n}^{\circ} 15, \S 72$ número marginal 3.

${ }^{66}$ Cfr. el cuadro estadístico incluido en EISENBERG, Jugendgerichtsgesetz, cit. nota ${ }^{\circ}$ 15, §72, p. 642.

${ }^{67}$ ROXIN, Claus, Strafverfahrensrecht. 24a edición, Múnich: Beck, 1995, § 30 número marginal 4.

${ }^{68}$ EISENBERG, Jugendgerichtsgesetz, cit. nota $\mathrm{n}^{\mathrm{o}} 15, \S 72$ número marginal 5b; ALBRECHT, Ist das deutsche Jugendstrafrecht...?, cit. nota $\mathrm{n}^{\circ} 63$, p. D 131.
} 
DUCE, Mauricio; COUSO, Jaime. "El derecho a un juzgamiento especializado de los jóvenes infractores en el derecho comparado".

aplicación", 69 restricción relevante si se tiene en cuenta que esta causal (o "fundamento") de aplicación de la prisión preventiva, en la praxis judicial, se emplea con más frecuencia para casos en que el delito imputado es menos grave, usualmente como un paraguas para ocultar otro tipo de razones, los denominados "fundamentos apócrifos" de la prisión, como la conveniencia de una "intervención en crisis" para prevenir nuevos delitos, o el interés en practicar una "terapia de choque" que genere en el adolescente adhesión a un tratamiento o medida alternativa, por ejemplo un tratamiento de drogas (en su caso, a través del llamado "taste of prison approach"), ${ }^{70}$ etc., ${ }^{71}$ y tiende a aplicarse de forma selectiva en perjuicio de adolescentes de un nivel socioeconómico bajo y de extranjeros (todos ellos, con una situación laboral y residencial más precaria). ${ }^{72}$

También la legislación de Costa Rica consagra como principio la excepcionalidad de la privación de libertad cautelar. Así, el artículo 59 de la Ley de Justicia Penal Juvenil de 1996 de Costa Rica (en adelante la "LJPJ") reconoce explícitamente esta idea señalando que “...la detención provisional tendrá carácter excepcional...". 73 Esta misma disposición realiza una diferenciación tratándose de los menores de entre 12 y 15 años, caso en el cual el uso de la privación de libertad durante el proceso debiera ser extremadamente excepcional, incluso en comparación con el caso de jóvenes de más de 15 y menos de 18 años. Al justificarse este principio, la doctrina de dicho país lo ha hecho apoyándose en la idea del daño potencial que la privación de libertad produciría en los jóvenes. ${ }^{74}$ No obstante lo anterior, en Costa Rica no pareciera existir un estatuto diferenciado para jóvenes y adultos respecto de las reglas generales que regulan la procedencia del supuesto material y la necesidad de cautela que justifica el uso de la prisión preventiva, ${ }^{75}$ así como tampoco contempla normas especiales de improcedencia de la misma, distintas de las establecidas

${ }^{69}$ La traducción es nuestra. La restricción es prácticamente la misma que contempla el $\S 113$, párrafo 2 , de la Ordenanza Procesal Penal alemana (StPO) para la aplicación de la prisión preventiva a mayores de edad imputados por delitos sancionados con multa o prisión de no más de seis meses, si bien el $\S 72$, párrafo 2 , de la JGG no incluye la causal de que el imputado "no pueda dar pruebas acerca de su identidad", que sí incluye, en cambio, el $\mathrm{n}^{\circ} 3$ del $\S 113$, párrafo 2, de la StPO).

${ }^{70}$ ALBRECHT, Ist das deutsche Jugendstrafrecht...?, cit. nota ${ }^{\circ}$ 63, p. D 131.

${ }^{71}$ LAUBENTHAL / BAIER, Jugendstrafrecht. cit. nota $\mathrm{n}^{\circ}$ 11, p. 124; EISENBERG, Jugendgerichtsgesetz, cit. nota $n^{\circ} 15, \S 72$ número marginal 9 .

${ }^{72}$ EISENBERG, Jugendgerichtsgesetz, cit. nota ${ }^{\circ}$ 15, §72 número marginal 6; ALBRECHT, Ist das deutsche Jugendstrafrecht...?, cit. nota $\mathrm{n}^{\mathrm{o}} 63, \mathrm{p} . \mathrm{D} 130$.

${ }^{73}$ Esta idea ha sido reforzada jurisprudencialmente por la Sala Constitucional de la Corte Suprema según tuvimos oportunidad de revisar en los párrafos previos. En estos mismos fallos la Corte ha sostenido que "En virtud del principio educativo que rige en el derecho penal juvenil, la prisión preventiva tiene en esta rama del derecho, un carácter aún más restrictivo que en el derecho penal de adultos". Véase Voto no $4836-99$ de 22 de junio de 1999, párrafo III y Voto no $7227-05$ de 9 de julio de 2005.

${ }^{74}$ Véase AMADOR, Gary, La Detención Provisional en la Ley de Justicia Penal Juvenil, San José: Editorial Jurídica Continental, 2006, p. 90.

${ }^{75}$ Un ejemplo de la aplicación de estos criterios puede verse en el Voto $n^{\circ}$ 95-04 de 2 de julio de 2004, del Tribunal de Casación Penal del Segundo Circuito Judicial de San José. En esta sentencia, el tribunal se hace cargo de los requisitos que deben ser cumplidos por el tribunal de instancia para decretar la internación provisoria, pudiéndose apreciar que, tanto en su contenido como en la lógica de su aplicación, ellos no distan de los establecidos en la legislación de adultos. Copia del fallo puede encontrarse en Fiscalía Penal Adjunta Juvenil, “10 Años de Jurisprudencia Penal Juvenil en Costa Rica 1996-2006”. San José, 2006, pp. 427-429. Un análisis sistemático de estas reglas puede verse en LLOBET, Javier, "La Detención provisional en la Justicia Penal Juvenil”, en AAVV, Derecho Penal Juvenil, San José: DAAD, 2002, pp. 203-250. 
Polít. crim. Vol. 7, N 13 (Julio 2012), Art. 1, pp. 1 - 73. [http://www.politicacriminal.cl/Vol_07/n_13/Vol7N13A1.pdf]

por la legislación procesal penal ordinaria, para el caso de los mayores de edad. ${ }^{76}$ Esto llevaría, en opinión de algunos, a que la forma en que los jueces aplican las reglas a los adolescentes no se diferencie mucho, en la práctica, de la manera en que ellas funcionan tratándose de los adultos. ${ }^{77}$

Un área problemática en donde se ha producido tensiones con la excepcionalidad en el uso de esta medida cautelar se produce respecto a la procedencia de la detención provisional en casos en donde el joven es imputado por un delito que no establece como sanción posible la privación de libertad (internación). En principio, en estos casos debería declararse improcedente la privación de libertad durante el proceso, ya que ella lesionaría el principio de proporcionalidad. Con todo, la Sala Constitucional de la Corte Suprema de Costa Rica ha validado su uso en aquellos casos excepcionales en los que no sea posible obtener por otro medio razonable el aseguramiento de la víctima o de los fines del proceso. ${ }^{78}$

No obstante lo anterior, existe la percepción de que el uso de la detención provisional es excepcional, particularmente a la luz de la existencia de un amplio catálogo de alternativas a ella, conocidas como órdenes de orientación y supervisión. ${ }^{79}$ En este sentido, se estaría siguiendo una de las recomendaciones emanadas de la legislación internacional, que promueve el uso de medidas alternativas a la privación de libertad como estrategia para hacer que ésta sea efectivamente excepcional.

El artículo 87 de la LJPJ de Costa Rica establece que el juez puede decretar la detención provisional o la imposición provisional de cualquiera de las órdenes de orientación y supervisión contempladas por la ley. De esta forma se establece la posibilidad de privilegiar el uso de las alternativas a la detención provisional, cuestión que ha sido luego objeto de desarrollo jurisprudencial de parte de la Corte Suprema ${ }^{80}$ Estas órdenes están contenidas en el art. 121 b) de la LJPJ, e incluyen la obligación de: (1) instalarse en un lugar de residencia determinado o cambiarse de él; (2) abandonar el trato con determinadas personas; (3) eliminar la visita a bares, discotecas o centros de diversión determinados; (4) matricularse en un centro de educación formal o en otro cuyo objetivo sea enseñarle alguna profesión u

\footnotetext{
${ }^{76}$ Véase CAMPOS, Mayra, "Análisis de la Detención Provisional en Materia Penal Juvenil (1 de enero al 30 de junio de 1998)", en AAVV, Lecciones Aprendidas. Ley de Justicia Penal Juvenil de Costa Rica, San José: UNICEF, 2000, pp. 79-90.

${ }^{77}$ Ello es cuestionado por Llobet quien, por ejemplo señala que “... mientras en el derecho penal de adultos por lo general se tiende a aplicar en forma casi automática la prisión preventiva cuando los hechos están sancionados con penalidad elevada, no ocurre así en la práctica de la justicia penal juvenil”. Véase LLOBET, "La Detención", cit. nota n ${ }^{\circ} 75$, p. 222.

${ }^{78}$ Véase Voto de la Sala Constitucional de la Corte Suprema de Costa Rica n ${ }^{\circ} 10132-2001$, de 9 de octubre de 2001. Un debate sobre este punto con opiniones de varios autores puede verse en AMADOR, Gary, "Algunos Problemas Respecto a la Aplicación de la Prisión Preventiva en el Proceso Penal Juvenil", en Revista de Ciencias Jurídicas, $\mathrm{n}^{\circ}$ 115, San José, Enero-Abril 2008, pp. 62-65.

${ }^{79}$ Véase Entrevista a Carlos Tiffer, 10 de octubre de 2008. Con datos empíricos de la primera etapa de funcionamiento de la LJPJ véase la opinión de CAMPOS, cit. nota ${ }^{\circ} 76, p$. 87. Esta misma autora repite la opinión en el siguiente texto: CAMPOS, Mayra, "El Ministerio Público: Órgano Promotor de la Justicia Juvenil y su Relación con la Policía Judicial", en De la Arbitrariedad a la Justicia: Adolescentes y Responsabilidad Penal en Costa Rica, San José: UNICEF, 2000, p. 428.

${ }^{80}$ Véase Entrevista a Tiffer, cit. nota $n^{\circ}$ 9, y CAMPOS, "El Ministerio Público", cit. nota ${ }^{\circ}$ 79, p. 427, citando la Sentencia de la sala Constitucional de la Corte Suprema 3614-99.
} 
DUCE, Mauricio; COUSO, Jaime. "El derecho a un juzgamiento especializado de los jóvenes infractores en el derecho comparado".

oficio; (5) adquirir trabajo; (6) abstenerse de ingerir bebidas alcohólicas, sustancias alucinógenas, enervantes, estupefacientes o tóxicos que produzcan adicción o hábito; y, (7) ordenar internamiento o el tratamiento ambulatorio en un centro de salud, público o privado, para desintoxicarlo o eliminar su adicción a las drogas antes mencionadas. ${ }^{81}$

Como puede apreciarse, se trata de un catálogo bastante amplio de alternativas al uso de la privación de libertad que, por lo mismo, ofrece opciones para dejar a ésta como último recurso. Con todo, la práctica en Costa Rica parece mostrar que existen una serie de problemas para un uso más efectivo de las medidas de orientación y supervisión. Por una parte, existe una crítica teórica importante que cuestiona la legitimidad al uso de estas medidas debido al hecho que varias de ellas no se orientan a satisfacer las necesidades de cautela previstas en la LJPJ que autorizan a las restricciones a la libertad (fines fundamentalmente cautelares o de protección del proceso). ${ }^{82}$ Se trataría de un problema derivado del hecho que las medidas de orientación y supervisión están reguladas fundamentalmente como consecuencias de la responsabilidad del joven y no cómo medidas cautelares propiamente tales, lo que genera algunas tensiones respecto a sus objetivos. ${ }^{83}$ Pero más allá de esto, se plantean problemas concretos como la falta de control de las medidas -lo que deslegitima su uso frente a los jueces ${ }^{84}-\mathrm{y}$ de diseño normativo, como el hecho de que el plazo máximo establecido por el propio artículo 87 de la LJPJ, para las órdenes de orientación y supervisión, no puede exceder de seis semanas. Ello dificultaría que cumpla las finalidades de cautela del proceso e incentivaría a que los fiscales soliciten la detención provisional que, como veremos, cuenta con plazos más amplios. ${ }^{85}$

La legislación española y la práctica jurisprudencial surgida en torno a ella muestran que también se trata de un sistema en el que no pareciera haber diferencias significativas, a favor de los jóvenes, en el uso de la prisión preventiva (internamiento provisional). ${ }^{86}$ En efecto, el artículo 28.1 de las LO 5/2000 establece como presupuestos básicos de la procedencia de la internación provisoria tanto la existencia de indicios racionales de que el delito ha sido cometido (supuesto material) como el que exista una necesidad concreta de su uso (necesidad de cautela), muy similares a los establecidos en la legislación de adultos. La revisión de las necesidades de cautela que la legislación española autoriza, especialmente a partir de la modificación realizada el año 2006, permite apreciar que se trata de causales bastante amplias, las que incluyen no sólo el peligro de fuga sino que también el riesgo de obstrucción a la justicia y el atentado contra los bienes jurídicos de la

\footnotetext{
${ }^{81}$ Un análisis detallado de cada una de las órdenes de orientación y supervisión puede revisarse en AMADOR, La Detención, cit. nota n 74 , pp. 347-370.

${ }^{82}$ Véase AMADOR, La Detención, cit. nota $n^{\circ}$ 74, y ARMIJO, Gilbert, "Las Alternativas a la Detención Provisional”, en Lecciones Aprendidas. Ley de Justicia Penal Juvenil de Costa Rica, San José: UNICEF, 2000, p. 105 (para quien, en todo caso, la discusión parece no ser tan relevante).

${ }^{83}$ LLOBET, “La Detención”, cit. nota n 75, p. 236 y 237.

${ }^{84}$ Véase ARMIJO, "Las alternativas", cit. nota $\mathrm{n}^{\circ} 82$, pp. 105 y 106.

${ }^{85}$ Véase AMADOR, La Detención, cit. nota ${ }^{\circ} 74$, pp. 370 y 371.

${ }^{86}$ Así lo sostiene Francisco Manuel García Ingelmo en la entrevista de mayo de 2008, cit. nota $n^{\circ} 9$. En ella sostuvo que en materia de prisión preventiva "no existen diferencias ni de principios ni de regulación normativa en favor del menor".
} 
Polít. crim. Vol. 7, N 13 (Julio 2012), Art. 1, pp. 1 - 73. [http://www.politicacriminal.cl/Vol_07/n_13/Vol7N13A1.pdf]

víctima. ${ }^{87}$ Además, el artículo 28.2 señala que para que se adopte la medida de internamiento debe atenderse a la gravedad de hechos, valorando siempre las circunstancias personales y sociales del menor, la existencia de un peligro cierto de fuga y si el menor hubiera cometido con anterioridad o no otros hechos graves de la misma naturaleza. ${ }^{88}$ No obstante esta cláusula abre el espectro de consideraciones sobre las cuáles los jueces deben determinar la procedencia del internamiento provisorio, la jurisprudencia del Tribunal Constitucional Español ha limitado la interpretación de la misma estableciendo con claridad que la gravedad del delito por sí sola no es suficiente para decretar esta medida cautelar. ${ }^{89}$ Con todo, esto deja abierto particularmente el tema de la consideración de las circunstancias "personales y sociales" del joven como fundamento para decidir la imposición de la prisión preventiva, en casos en los que no se dan las necesidades de cautela específicas contenidas en la ley. ${ }^{90}$ Una revisión de diversa jurisprudencia emanada de audiencias provinciales también nos muestra que en el día a día el razonamiento de los tribunales no difiere significativamente respecto del tipo de argumentación utilizada respecto de adultos. ${ }^{91}$

Al igual que en Costa Rica, la legislación española establece un conjunto de medidas cautelares personales distintas al internamiento provisorio que buscan ofrecer alternativas al uso de ésta y así asegurar su excepcionalidad. El artículo 28.1 de la LO 5/2000 establece, como posibles medidas cautelares alternativas, la libertad vigilada, la prohibición de aproximarse o comunicarse con la víctima o con aquellos de sus familiares u otras personas que determine el juez y la prohibición de convivencia con otra persona, familia o grupo educativo. Se trata de menos opciones que en el caso de Costa Rica y tampoco exentas de polémica, especialmente la referida a la prohibición de convivencia, que es vista por un sector de la doctrina como una medida inapropiada a los fines de cautela. ${ }^{92}$

En los Estados Unidos la regulación que es posible identificar a nivel estatal también presenta algunos aspectos positivos, pero a la vez varias cuestiones problemáticas en materia de especialidad y excepcionalidad. El principio rector que orienta a la mayoría de las jurisdicciones es la idea básica de que la prisión preventiva debiera ser procedente sólo en casos en que sea necesario y de manera excepcional (al igual que el caso de adultos). Con todo, diversos Estados admiten como causales de procedencia situaciones bastante

\footnotetext{
${ }^{87}$ Estas últimas fueron agregadas en la LO 8/2006. Véase DÍAZ, Manuel; LUACES, Ana, "El proceso Penal de menores (I)", en Derecho Penal Juvenil, Madrid: Editorial Dykinson, 2007, pp. 380-381.

${ }^{88}$ En su redacción actual esta disposición representa un avance importante respecto a su versión original en términos de reforzar el sentido cautelar en el uso de esta medida ya que se eliminó una referencia muy problemática al criterio de la "repercusión y la alarma social producida" por el hecho como factor para decidir la procedencia del internamiento provisorio.

${ }^{89}$ Véase ORNOSA FERNÁNDEZ, Derecho, cit. nota n ${ }^{\circ} 32$, p. 354.

${ }^{90}$ Así lo sostiene Francisco Manuel García Ingelmo en la entrevista de mayo de 2008, cit. nota $n^{\circ}$ 9.En ella nos indicó que el hecho que la ley establezca la consideración de las circunstancias personales de los jóvenes (como por ejemplo su desamparo) podrían dar lugar a internaciones que no se otorgarían tratándose de adultos.

${ }^{91}$ A modo ejemplar pueden verse resoluciones 93/2003 y 94/2003 de 28 de octubre de 2003 y 97/2003 de 13 de noviembre de 2003, todas de la Audiencia Provincial de Madrid; las resoluciones 9349/2004 del 14 de julio de 2004, 8961/2005 del 15 de julio de 2004 y 355/2006 de 24 de mayo de 2006, todas de la Audiencia Provincial de Barcelona.

${ }_{92}$ Véase ORNOSA FERNÁNDEZ, Derecho, cit. nota n ${ }^{\circ} 32$, pp. 365 y 366.
} 
DUCE, Mauricio; COUSO, Jaime. "El derecho a un juzgamiento especializado de los jóvenes infractores en el derecho comparado".

abiertas, incluyendo dentro de ellas la posibilidad de que el joven vuelva a cometer un delito en el futuro. ${ }^{93}$ También se ha considerado que las reglas constitucionales y legales de adultos referidas a las fianzas no son aplicables en las cortes juveniles, no obstante algunos Estados las han extendido y han hecho aplicables a los jóvenes objeto de persecución penal. ${ }^{94}$ En consecuencia, se trata de un régimen que permite - al menos desde el punto de vista de diseño normativo- un uso más abierto de la prisión preventiva que tratándose de adultos, ${ }^{95}$ aún cuando con importantes restricciones temporales como veremos en la próxima sección.

\subsubsection{Duración o Extensión Temporal de la Prisión Preventiva}

La afirmación de la garantía de la libertad individual no sólo debe traducirse en una preocupación en el uso restringido de la privación de libertad durante el proceso seguido en contra de jóvenes, sino que también debe reflejarse, en los casos excepcionales en que sea procedente, en restricciones temporales muy estrictas a su extensión. En este sentido, tuvimos oportunidad de mencionar en el trabajo base del presente que, en los tres instrumentos internacionales específicos en materia de proceso juvenil, el énfasis en la regulación de la garantía específica en la materia está en la idea que el plazo de privación de libertad durante el proceso en contra de un joven sea "lo más breve posible", lo que constituye un lenguaje mucho más estricto que la noción más abierta de "plazo razonable" establecida para adultos. ${ }^{96}$ En este contexto, el Comité de Derechos del Niño recomienda dos tipos de acciones legislativas a los Estados parte para hacer efectivo este derecho. Por una parte, la necesidad de que las leyes internas establezcan límites temporales a la duración de la prisión preventiva y, por la otra, un sistema de examen o revisión periódica de la misma. ${ }^{97}$

La observación de las cuatro legislaciones en estudio nos muestra que en general los países se hacen cargo de esta garantía específica recurriendo a mecanismos similares a los que han sido recomendados por el Comité de Derechos del Niño, particularmente en la idea de establecer limitaciones temporales fijas para la duración de la internación provisional. ${ }^{98}$

Costa Rica y España son un buen ejemplo de establecimientos de plazos máximos de duración de la prisión preventiva. En el primero de estos, el artículo 59 inciso segundo de la LJPJ establece como límite temporal máximo dos meses, plazo que puede ser prorrogado hasta por un máximo de dos meses más. En el caso español, el artículo 28.3 de la LO

\footnotetext{
${ }^{93}$ Corte Suprema ha validado esto en Schall v. Martin año 1984, ver GARDNER, Understanding, cit. nota $n^{\circ}$ 43 , p. 250 a 252.

${ }^{94}$ BOCKRATH, Joseph T., Right of Bail in Proceedings in Juvenile Courts, American Law Reports $\mathrm{n}^{\mathrm{o}} 53$ (originalmente publicado en 1973 y actualizado a 2008).

95 Una descripción general del tema puede revisarse en BREITENBACH, Eugene, "Juvenile Court Proceedings", American Jurisprudence Trials, no 137, 2008 (updated), párrafos 47 a 54.

${ }^{96}$ Véase DUCE, cit. nota ${ }^{\circ} 1$, pp. 88-89.

${ }^{97}$ Véase Comité de Derechos del Niño, OG/10, párrafo 80.

${ }^{98}$ No pareciera haber en cambio un desarrollo normativo claro en las legislaciones analizadas de sistemas de revisión periódicos de las detenciones provisionales que sean con la frecuencia recomendada en la legislación internacional (cada dos semanas) y especiales para los jóvenes.
} 
Polít. crim. Vol. 7, N 13 (Julio 2012), Art. 1, pp. 1 - 73.

[http://www.politicacriminal.cl/Vol_07/n_13/Vol7N13A1.pdf]

5/2000 plazo máximo seis meses, ${ }^{99}$ prorrogables por otros tres más como máximo a instancia del fiscal y por resolución motivada del juez. ${ }^{100}$ Como se puede observar, se trata de plazos bastante más estrictos que los que rigen para el proceso y la prisión preventiva de adultos, en las legislaciones de esos mismos países. ${ }^{101}$

Además de estas normas de plazo, la legislación de Costa Rica establece otras reglas que refuerzan la idea de duración temporal limitada de la internación provisoria de jóvenes. Así, el artículo 52 de la LJPJ, establece una regla según la cual los plazos procesales establecidos en la misma ley para desarrollar el proceso juvenil se transforman en improrrogables cuando hay un joven privado de libertad y a su vencimiento se caduca la facultad respectiva. En cambio, si se trata de jóvenes no privados de libertad, dichos plazos son prorrogables de acuerdo a las reglas generales. Todo ello se complementa con una norma de carácter general contenida en el artículo 60 de la LJPJ que establece el principio de "máxima prioridad", según el cual tanto los tribunales penales juveniles como los órganos encargados de la investigación deben darle esa prioridad a la tramitación de un caso en la que un joven esté en situación de detención provisional. Con todo, a diferencia del mecanismo del artículo 52 se trata de una norma más bien programática sin efectos muy concretos o precisos.

En este contexto positivo, la jurisprudencia de Costa Rica ha desarrollado algunas posibilidades adicionales de ampliación del plazo de la detención provisional de los jóvenes que elevan significativamente las limitaciones ya revisadas. Se trata de los casos en los que los jóvenes han sido condenados por decisión de instancia y el fallo no se encuentra ejecutoriado debido a la existencia de recursos pendientes. La Sala Constitucional de la Corte Suprema ha sostenido reiteradamente que estas hipótesis se hace aplicable la regla del artículo 258 del Código Procesal Penal de dicho país que permite una prórroga de hasta por seis meses de la detención provisional. Con todo, al momento de decretarse la prórroga, el tribunal debe fijar un plazo concreto dentro del límite máximo permitido por la ley. ${ }^{102}$

\footnotetext{
${ }^{99}$ La redacción original de la LO 5/2000 establecía como duración máxima los tres meses. Un sector de la doctrina que criticaba con mucha fuerza la poca flexibilidad del plazo argumentando que la ley "carece en este punto de un escaso sentido de la realidad". Véase TAMARIT, Joseph, "Principios Político Criminales y Dogmáticos del Sistema Penal de Menores", en Justicia Penal de Menores y Jóvenes, Barcelona: Tirant Lo Blanch, 2002, p. 45. El límite fue ampliado luego por la reforma introducida por la LO 8/2006 de 4 de diciembre de 2006 con lo que el efecto limitador de esta disposición es bastante más modesto que en el diseño original de la ley.

${ }^{100}$ La jurisprudencia española tiende aparentemente a ser bastante estricta respecto a las posibilidades de prórroga del plazo. Véase por ejemplo Auto 2/2000 de 22 de marzo de 2000de la Sección Cuarta de la Audiencia Provincial de Madrid en la que se rechaza una solicitud de prórroga por faltar algunas mínimas diligencias de investigación.

${ }^{101}$ En Costa Rica el plazo máximo establecido para la extensión de la prisión preventiva tratándose de adultos contando sus prórrogas es de dos años y seis meses. En el caso de los jóvenes lo máximo que podría extenderse es cuatro meses si es que se prorroga por el máximo establecido por la ley. Véase AMADOR, $L a$ Detención, cit. nota $\mathrm{n}^{\circ} 74$, p. 121. En el caso Español, el artículo 504 de la ley de Enjuiciamiento Criminal permite que en delitos de mediana y alta gravedad la prisión preventiva tenga extensiones temporales de 1 y 2 años ampliables a 2 y 4 respectivamente.

${ }^{102}$ Véase Sentencia de la Sala Constitucional de la Corte Suprema de Costa Rica n ${ }^{\circ}$ 04266-2002 de 13 de mayo de 2002. En ella se cita también otro fallo sobre el mismo tema y en donde se sostiene la misma postura. Véase sentencia ${ }^{\mathrm{o}}$ 04836-1999 de 22 de junio de 1999. Esta jurisprudencia no ha sido seguida completamente por el Tribunal de Casación Penal de San José, así hemos identificado al menos un caso en
} 
DUCE, Mauricio; COUSO, Jaime. "El derecho a un juzgamiento especializado de los jóvenes infractores en el derecho comparado".

Como puede observarse, si es que hay condena el plazo adicional que podría entregarse supera el plazo máximo completo de todo el proceso. Esto se explica en buena medida como consecuencia que la norma utilizada para justificar dicha ampliación de plazos de la detención provisoria está prevista para adultos en donde mencionamos los plazos son mucho más extensos, consistente con el hecho que las exigencias internacionales no sean tan estrictas.

En los Estados Unidos la limitación temporal al uso de la prisión preventiva está asociada a la cláusula constitucional que establece el derecho a un juicio rápido (speedy trial). ${ }^{103}$ Todavía no existe una posición clara en la jurisprudencia de dicho país respecto a la aplicabilidad de la garantía constitucional en materia juvenil ya que no hay una decisión de la Corte Suprema que de manera explícita haya hecho extensivo este derecho a la materia. ${ }^{104}$ Con todo, ella se encuentra recogida a nivel legal en buena parte de los Estados y también en la jurisprudencia de cortes estatales. ${ }^{105}$ En estas regulaciones se establecen diversos plazos de duración máxima de la privación de libertad de jóvenes durante el proceso $^{106}$ y consecuencias a su incumplimiento. ${ }^{107}$ En general, se puede apreciar una protección bien intensa de la extensión temporal de la prisión preventiva, aún cuando los mecanismos y consecuencias para el control sean similares a los que se utilizan tratándose de adultos.

A nivel federal, la sección 5036 de la FJDA establece la garantía de juicio rápido (speedy trial) en favor de los jóvenes detenidos, estableciendo su derecho a ser llevado a juicio en un plazo máximo de 30 días desde el momento en que la detención comenzó. La jurisprudencia de dicho país entiende que se trata de una detención cuando se está en presencia de una custodia no voluntaria en manos de autoridades federales una vez que se han imputado cargos, pero sin incluir el período que corre entre la admisión de culpabilidad y la dictación de la sentencia. ${ }^{108}$ La propia sección establece las excepciones admitidas a los 30 días. Se trata de tres hipótesis: (a) cuando el retardo adicional ha sido causado por el joven o su abogado; (b) cuando el retardo adicional ha sido consentido por el joven y su abogado; y, (c) cuando el retardo es justificado por un interés en la justicia. Sobre esta última excepción existe variada jurisprudencia de las cortes federales de dicho país que ha

donde esta tribunal ha seguido una posición diversa a la plateada por la sala Constitucional. Véase Voto $\mathrm{n}^{\circ} 86-$ 04 de 10 de febrero de 2004 según el cual la prórroga del artículo 258 no se aplicaría en el ámbito juvenil (voto de mayoría). Sobre este punto incluyendo párrafos de fallos diversos puede verse LLOBET, "La Detención", cit. nota $n^{\circ} 75$, pp. 242-244.

${ }^{103}$ En términos generales sobre la garantía véase DRESSLER, Joshua; MICHAELS, Alan, Understanding Criminal Procedure Vol. 2, New York: Mathew Bender, 2006, pp. 163-174.

${ }^{104}$ Véase SHEPHERD, "Still Seeking”, cit. nota n 44, y BREITENBACH, "Juvenile”, cit. nota n 95, párrafo 36.

105 Ídem.

${ }^{106}$ Se trata en general de plazos incluso más estrictos que los que hemos visto en países como España y Costa Rica. Por ejemplo, en el Estado de Georgia se establece un plazo de 10 días para realizar la audiencia de juicio desde la imputación de cargos si el joven está detenido o 60 días si está en libertad, los que en todo caso podrían ser ampliables. En el Estado de Nuevo México esos plazos aumentan a 30 y 120 días respectivamente.

${ }^{107}$ Estas pueden ir desde la liberación del joven imputado en caso de exceso de plazo o derechamente a poner término a la persecución penal.

${ }^{108}$ Véase RADLER, cit. nota $n^{\circ} 50$, párrafo $15(\mathrm{a})$. 
Polít. crim. Vol. 7, No 13 (Julio 2012), Art. 1, pp. 1 - 73.

[http://www.politicacriminal.cl/Vol_07/n_13/Vol7N13A1.pdf]

admitido en reiteradas ocasiones que una detención por un plazo superior a los 30 días podría no constituir una violación de la FJDA en la medida que la demora hubiera sido explicada por una razón de "interés de la justicia" considerando, en todo caso, que no quedan cubiertos por la excepción las demoras producto de la congestión de la agenda de los tribunales. ${ }^{109}$

La sección 5036 establece también con claridad la sanción en caso de incumplimiento de la cláusula de Speedy Trial sin que exista una excepción justificada. Se trata de una sanción severa ya que consiste en la desestimación del caso sin llegar al juicio (dismissal on motion).

En el caso de la JGG alemana, a diferencia de varias de las jurisdicciones mencionadas más arriba, no se contempla un límite temporal máximo específico para la prisión preventiva de adolescentes. Por ello, rigen los límites generales de la prisión preventiva de adultos, de los $\S \S 121$ y ss. de la StPO, que, en cualquier caso, son bastante exigentes, disponiendo como duración máxima, por regla general, 6 meses, plazo que sólo podrá extenderse por disposición de un tribunal superior (el Oberlandesgericht), en atención a la especial gravedad del hecho, a la especial envergadura de la investigación o a otro motivo grave, siendo prescriptiva, en tal caso, una nueva revisión cada tres meses; esa misma regulación general establece que la prisión preventiva basada en la causal de peligro de reiteración en caso alguno podrá durar más de un año. Más allá de esos plazos máximos generales, el § 72 , párrafo 5 , de la JGG establece un deber judicial de "conducir el proceso con especial celeridad" cuando un adolescente se encuentra en prisión preventiva. Este deber, de acuerdo con la jurisprudencia y la praxis judicial de dicho país, se traduce en exigencias organizacionales concretas, como la de separar los procedimientos seguidos contra imputados que se encuentren en prisión preventiva, reproducir copias de las carpetas de actuaciones procesales para el defensor de cada imputado, etc., medidas que, de no adoptarse, pueden dar lugar a la revocación de la medida cautelar. ${ }^{110}$

Por otra parte, también como una forma de reducir la duración temporal de la prisión preventiva, en Alemania se asigna gran importancia a la tarea que corresponde al Servicio de Asistencia a los Tribunales Juveniles en la creación de condiciones que permitan adoptar medidas sustitutas de la prisión preventiva, si es que no ha podido evitarse desde un inicio, gracias a esas condiciones, el decreto de aquella medida cautelar. ${ }^{111}$ En cumplimiento de esa tarea, en muchas jurisdicciones se cuenta con un funcionario de tal servicio los 7 días de la semana, las 24 horas del día, disponible para recibir la notificación prescrita por la ley, cada vez que sea de detenido un menor de edad, momento a partir del cual rige el deber de crear las condiciones que permitan evitar la prisión preventiva o su sustitución, lo más pronto posible ${ }^{112}$.

\footnotetext{
${ }^{109}$ RADLER, cit. nota ${ }^{\circ} 50$, párrafos 15 (c), (d) y (e).

${ }^{110}$ EISENBERG, Jugendgerichtsgesetz, cit. nota $\mathrm{n}^{\mathrm{o}} 15$, $\$ 72$ número marginal 17, citando jurisprudencia en ese sentido.

${ }^{111}$ Entrevista a Ulrich Eisenberg.

${ }^{112}$ Ibídem.
} 
DUCE, Mauricio; COUSO, Jaime. "El derecho a un juzgamiento especializado de los jóvenes infractores en el derecho comparado".

Como contrapartida, sin embargo, en su relación con la pena privativa de libertad que le sucede, la regulación de la prisión preventiva en Alemania no respeta el principio que prescribe reducir al mínimo su duración, cuando el $\S 52$ a de la JGG permite al tribunal decidir no imputar a la pena privativa de libertad impuesta el tiempo de prisión preventiva ya cumplido, si la imputación pudiese impedir obtener el "efecto educativo" esperado de la pena, lo que especialmente ocurre cuando, tras la imputación del tiempo de prisión preventiva, restarían menos de seis meses de cumplimiento de pena privativa de libertad. ${ }^{113}$

\subsubsection{Condiciones de Cumplimiento de la Prisión Preventiva}

Las condiciones de cumplimiento de la prisión preventiva representan otra área en donde identificamos la existencia de un conjunto de garantías específicas en favor de los niños y jóvenes imputados que no se contemplan en favor de los adultos en la legislación internacional.

Señalamos que la manifestación más evidente de estas condiciones especiales es la necesidad que exista separación entre adultos y jóvenes sometidos a prisión preventiva. La revisión de la legislación comparada muestra que se trata de un elemento reconocido ampliamente a nivel normativo, no obstante presentarse diversos problemas en su cumplimiento práctico.

Así, el $\S 93$ de la JGG alemana y el $§ 78$ de la Ordenanza de Ejecución de la Prisión preventiva (Untersuchungshaftvollzugsordnung, UVollzO) contemplan el principio de separación entre adolescentes y mayores de edad, en la ejecución de esta medida cautelar, que se suma al principio general (no sólo para adolescentes) de separación entre condenados a penas privativas de libertad e imputados sometidos a prisión preventiva. Esta doble exigencia de separación, sin embargo, provoca dificultades, en varias jurisdicciones, para el cumplimiento de alguna de ellas, a falta de secciones especiales para adolescentes en los centros de cumplimiento de la prisión preventiva, caso en que, la doctrina promueve claramente la ejecución de la media cautelar en centros de cumplimiento de penas privativas de libertad para adolescentes o en centros de cumplimiento de la pena de arresto juvenil. ${ }^{114}$ La regulación especial para adolescentes contemplada por los $\S \S 77$ a 85 de la UVollzO considera, además, otros derechos especiales de los adolescentes sometidos a prisión preventiva, en particular, en relación con el acceso a formación a instrucción, libros, diarios y revistas, actividades deportivas, contacto con el exterior, etc. Más en general, tanto estas normas, como el $\S 93$ de la JGG, exigen que la ejecución de esta medida cautelar se configure de forma educativa, lo que, sin embargo, ha sido criticado como una intervención injustificada en los derechos parentales a dirigir la educación de sus hijos (todavía no sujetos a una potestad especial del estado de intervenir educativamente en sus

\footnotetext{
${ }^{113}$ Así se interpreta judicialmente, según se desprende de la entrevista a Frieder Dünkel, quien, no obstante criticar la disposición, advierte, con todo, que tiene muy poca aplicación práctica. Críticamente, también, ALBRECHT, Ist das deutsche Jugendstrafrecht...?, cit. nota ${ }^{\circ}$ 63, p. D 132.

${ }^{114}$ LAUBENTHAL / BAIER, Jugendstrafrecht. cit. nota $\mathrm{n}^{\mathrm{o}}$ 11, p. 127; EISENBERG, Jugendgerichtsgesetz, cit. nota $\mathrm{n}^{\mathrm{o}} 15, \S 93$ número marginal $10-10^{\mathrm{a}}$, con referencias, además, a la situación de las adolescentes (de sexo femenino), que cumplen la prisión preventiva predominantemente en centros de adultas.
} 
Polít. crim. Vol. 7, N 13 (Julio 2012), Art. 1, pp. 1 - 73. [http://www.politicacriminal.cl/Vol_07/n_13/Vol7N13A1.pdf]

vidas, que recién surgiría, una vez vencida la presunción de inocencia, con la condena a una pena con finalidad educativa). ${ }^{115}$

El artículo 27 LJPJ Costa Rica, por su parte, regula las hipótesis de internamiento de jóvenes privados de libertad estableciendo que no importando que ésta sea provisional o definitiva, ellos tienen el derecho a ser internados en un centro exclusivo para menores de edad (esta regla se repite en al artículo 58 de la LJPJ, pero referido exclusivamente a la detención provisional). Resulta interesante que la norma en análisis está redactada en clave de "derecho" del joven y no como una orden de organización administrativa que hace el legislador, lo cual satisface la exigencia contenida en el sistema internacional. ${ }^{116}$

El artículo 27 de la LJPJ también se regula la situación de los jóvenes privados temporalmente de libertad como consecuencia de una detención policial. En dicho caso se establece la necesidad que la policía destine áreas especiales para su detención y remita a los jóvenes lo antes posible a los centros especializados. Sobre este último aspecto de la regla existe un cierto debate en cuanto a la existencia de problemas de falta de segregación en cuarteles policiales. ${ }^{117}$

La separación de jóvenes y adultos en centros de privación de libertad también es regla reconocida de manera explícita en la legislación española. El artículo 17.3 de la LO 5/2000 regula que la detención de los jóvenes debe realizarse en "dependencias adecuadas y separadas de las que se utilicen para los mayores de edad". Esta regla se refuerza con lo dispuesto en el artículo 54 de la misma ley que regula con mayor detenimiento el mismo aspecto. En efecto, el artículo 54.1 se señala que tanto las medidas privativas de libertad, la detención y las medidas cautelares se deberán ejecutar en centros específicos para menores infractores diferentes de los adultos. El artículo 54.3 va un poco más allá al establecer la necesidad que los centros de internación juvenil se dividan de acuerdo a la edad madurez, necesidades y habilidades sociales de los jóvenes internados.

La legislación española también es explícita en el reconocimiento del conjunto de otros derechos asociados a las condiciones en que se debe cumplir la prisión preventiva. El artículo 17.3 de la LO 5/2000 establece que durante la privación de libertad los jóvenes recibirán cuidados, protección, asistencia social, psicológica, médica y física que requieran. Se trata, con todo, de una norma bastante abierta y programática.

En el sistema federal de los Estados Unidos la sección 5035 de la FDJA se ocupa del tema de regular algunas condiciones básicas de cumplimiento de la prisión preventiva en los jóvenes privados de libertad conforme al sistema juvenil federal. La regla general es que la privación de libertad de un joven debe llevarse adelante en un recinto juvenil, pero se establece la posibilidad de que el fiscal general designe un lugar distinto en la medida que sea adecuado. En todo caso, se establece el principio de separación ya que se ordena que ningún joven pueda estar privado de libertad con adultos, ya sea condenado o en espera de

\footnotetext{
${ }^{115}$ LAUBENTHAL / BAIER, Jugendstrafrecht. cit. nota $\mathrm{n}^{\circ}$ 11, p. 127.

${ }^{116}$ En este sentido también véase TIFFER, "La Ley de Justicia", cit. nota $n^{\circ} 26$, p. 78, quién además señala que este derecho es consecuencia del principio de especialidad contemplado en el artículo 12 de la LJPJ.

${ }^{117}$ Véase AMADOR, La Detención, cit. nota n ${ }^{\circ} 74$, p. 210 y 211 ,
} 
DUCE, Mauricio; COUSO, Jaime. "El derecho a un juzgamiento especializado de los jóvenes infractores en el derecho comparado".

su juicio. Además, se establece un mandato en términos de evitar al máximo el contacto de jóvenes en prisión preventiva con otros que ya estén condenados. No se trata en todo caso de una prohibición absoluta de contacto sino que una orientación deseable. Finalmente, la sección 5035 establece también un conjunto de otros derechos respecto del joven privado de libertad en prisión preventiva estableciendo que durante su detención se les debe proveer comida, calefacción, luz, facilidades sanitarias, cama, ropa, recreación, educación y cuidados médicos (incluyendo tratamiento psiquiátrico y psicológico y otro tipo de cuidados y tratamientos), todos ellos en un estándar "adecuado".

\subsection{Exigencias más Estrictas Respecto a la Extensión Temporal del Proceso}

Según se analizó en el primer trabajo de esta investigación, la extensión temporal de los procesos es una preocupación muy importante en el sistema internacional de derechos humanos a tal punto que una garantía central del debido proceso es el derecho a ser juzgado en un plazo razonable. Las ideas que fundamentan a esta garantía tienen que ver tanto con el impacto negativo que la extensión temporal del proceso produce en los derechos de las personas imputadas (extendiendo en demasía el estado de incertidumbre generado por el proceso, dificultando la posibilidad de ejercer derecho de defensa, entre otros) como en la legitimidad del sistema frente a la comunidad. ${ }^{118}$ Estas razones han hecho que se trate de una garantía con amplio reconocimiento en el derecho comparado.

Como ya vimos, dicha garantía ha sido reconocida de una forma especial por la legislación internacional juvenil al exigirse que en los procesos en contra de niños y jóvenes infractores la duración total del proceso para ellos debiera ser más breve que tratándose de adultos, aún cuando no hubiera privación de libertad en su desarrollo. ${ }^{119}$

El mecanismo principal a través del cual esta garantía se regula en el derecho comparado es a través de establecimiento de plazos máximos de duración del proceso que en general tienden a ser bastante más breves que los existentes en los procesos de adultos. En esta dirección es posible constatar que se está en presencia de una característica común en los cuatro ordenamientos objeto de estudio.

Un caso ejemplar de análisis en este tema es España. El diseño del procedimiento juvenil contenido en la LO 5/2000 está basado en el procedimiento abreviado regulado por la Ley de Enjuiciamiento Criminal de adultos. ${ }^{120}$ Esto implica desde su diseño se trata de un proceso que está pensado de una manera más simple (con menos trámites y etapas procesales) y, por lo mismo, con una posibilidad menor de extenderse temporalmente en forma excesiva. Esto se refuerza luego con el establecimiento de plazos relativamente breves en las distintas fases procesales reguladas en los artículos 31 a 38 de la ley (por ejemplo el plazo para dictar sentencia de cinco días previsto en el artículo 38). Pero más allá de la regulación normativa, la idea que el derecho de los jóvenes a ser juzgados en un plazo razonable es más estricto que el de los adultos ha sido recogido por la jurisprudencia del Tribunal Constitucional con bastante fuerza. Es así como ya en el año 1991, aún antes

\footnotetext{
${ }^{118}$ Véase, DUCE, cit. nota $n^{\mathrm{o}} 1$, pp. 93-94.

119 Ídem.

${ }^{120}$ Véase ORNOSA FERNÁNDEZ, Derecho, cit. nota no 32, p. 99.
} 
Polít. crim. Vol. 7, N 13 (Julio 2012), Art. 1, pp. 1 - 73. [http://www.politicacriminal.cl/Vol_07/n_13/Vol7N13A1.pdf]

de la vigencia de la LO 5/2000, el Tribunal Constitucional tuvo oportunidad de señalar que el derecho a un proceso sin delaciones indebidas debía ser respetado también tratándose de los procesos seguidos contra menores. ${ }^{121}$ En un fallo más reciente, el Tribunal Constitucional ha señalado de manera explícita que "La tardanza excesiva en la finalización de los procesos puede tener sobre el afectado unas consecuencias especialmente perjudiciales cuando se trata de un supuesto en el que se depura la eventual responsabilidad penal de un menor. La dimensión temporal merece una consideración diferente en la llamada justicia de menores"122 asumiendo la idea que el plazo razonable debe ser más estricto. Con todo, al momento de justificar las razones de esta postura, nos parece que el Tribunal Constitucional tiende a confundir el carácter de garantía de la idea de plazo razonable con el rol que cumplen los procesos breves en asegurar los fines educativos del procedimiento juvenil. Así, el tribunal señala “...si la respuesta de los órganos jurisdiccionales se demora en el tiempo, un postulado básico en estos procedimientos, el superior interés del menor, queda violentado, así como distorsionada la finalidad educativa que los procesos de menores han de perseguir...". ${ }^{123}$

La regulación del proceso juvenil en Costa Rica se estructura sobre la base de ideas similares a las reguladas en el ordenamiento español. En efecto, el diseño del proceso está pensado desde una lógica de brevedad y sencillez que representa una simplificación importante que el proceso penal de adultos. ${ }^{124}$ Como complemento de ellos los plazos entre las distintas etapas procesales son muy breves. ${ }^{125}$ Finalmente, se regulan procedimientos especiales con menor cantidad de pasos y etapas que el procedimiento ordinario, como es el caso de los hechos sorprendidos en flagrancia, en los cuáles el artículo 79 de la LJPJ establece que el fiscal tiene el deber de presentar su acusación dentro de los cinco días siguientes a la detención. Es decir, hay un diseño procesal pensado en asegurar el cumplimiento del plazo razonable, entendiendo que éste requiere reglas más estrictas para los jóvenes. La importancia del tema se puede ver también en que la LJPJ entrega competencia de manera explícita, en su artículo 30 letra b), al Tribunal Superior Penal Juvenil para controlar el cumplimiento de los plazos fijados en la misma. Se trata, en consecuencia, de un mecanismo de control adicional al que el propio juez del caso debiera realizar.

A nivel más general, la garantía del plazo razonable también ha sido reconocida por la jurisprudencia de la Sala Constitucional de la Corte Suprema en Costa Rica. Así, por ejemplo, en una decisión del año 1996 la Sala señaló “...La autoridades públicas deben

\footnotetext{
${ }^{121}$ Véase STC 36/1991 de 14 de febrero de 1991.

${ }^{122}$ Véase STC $153 / 2005$ de 8 de julio de 2005 párrafo II.3.

${ }^{123}$ Idem.

${ }^{124}$ En este sentido Carlos Tiffer señaló en su entrevista que el proceso penal juvenil "Está estructurado completamente distinto. Primero es un proceso que no está estructurado en fases, es un proceso que se diferencia del de adultos porque no tiene la rigidez ni el carácter lineal, en comparación con el de adultos". Véase entrevista a Carlos Tiffer, cit. nota ${ }^{\circ} 9$.

${ }^{125}$ Por ejemplo, de acuerdo al artículo 98, una vez admitidas las pruebas, en la misma resolución el juez debe citar a la audiencia de debate dentro de los 15 días siguientes. Véase también el artículo 95 que contiene los plazos para el ofrecimiento de prueba. Sobre este punto Tiffer señala "Uno de los principios fundamentales establecidos en esta Ley, es el principio de celeridad. En virtud del cual, los plazos establecidos en la LJPJ, son cortos". Véase TIFFER, "La Ley de Justicia", cit. nota n 26, p. 86.
} 
DUCE, Mauricio; COUSO, Jaime. "El derecho a un juzgamiento especializado de los jóvenes infractores en el derecho comparado".

actuar con la mayor celeridad posible en apego al principio de justicia pronta y cumplida, sin que su inercia los derechos fundamentales del acusado". ${ }^{126}$ Con todo, al igual que la jurisprudencia del Tribunal Constitucional Español, la doctrina que se refiere al derecho del joven a ser juzgado en un plazo razonable tiende a asociar el fundamento de este derecho con el fin educativo del mismo ${ }^{127}$, lo que nuestra opinión debilita su comprensión como derecho fundamental.

En Alemania, por su parte, el "principio de celeridad" (Beschleunigungsprinzip) supuestamente forma parte de las notas distintivas del proceso penal de adolescentes, pero no está expresamente establecido en la ley, si bien se expresa en determinadas particularidades de la regulación, como la reducción de las posibilidades de impugnar ciertas decisiones judiciales (especialmente, la exclusión de los recursos en contra de la determinación de la naturaleza y cuantía de las medidas no privativas de libertad) o las normas sobre el procedimiento simplificado y las que permiten emplear estrategias de "diversificación". ${ }^{28} \mathrm{Su}$ fundamento se formula, a veces, en función de necesidades educativas asociadas a una sanción pronta (lo que se supone necesario para un "efecto educativo" de la misma); a veces, en función de la protección del adolescente en contra de los efectos negativos de una exposición muy prolongada a la justicia penal - no sólo en el caso más evidente del adolescente sometido a prisión preventiva - así como en contra de la carga que para una persona de su edad significa la incertidumbre y miedo frente al desenlace que podría tener el proceso. ${ }^{129}$

Este principio, con todo, entra en tensión con las exigencias de un "proceso justo", por una parte (amenazado precisamente por la restricción de las posibilidades de recurrir en contra de las sentencias, entre otras medidas); ${ }^{130}$ y con el interés de alcanzar un "resultado de calidad", ${ }^{131}$ por otra parte, que podría requerir de más tiempo para buscar opciones y permitirle al tribunal barajarlas y configurarlas (por ejemplo, una conciliación entre autor y víctima $^{132}$ ). En cualquier caso, se ha observado críticamente que estas diferencias introducidas en el proceso penal de adolescentes, en comparación con el de adultos, en lo que atañe a su ritualidad y etapas, no siempre están al servicio de la celeridad, ni sirven siempre a la protección de los intereses del adolescente, pues algunas de ellas más bien tienden a demorar el proceso, al servicio de otros intereses, como las disposiciones sobre la investigación de la personalidad del adolescente, por parte de la Asistencia a los Tribunales Juveniles, o las que prohíben aplicar el "procedimiento acelerado" o el "procedimiento por mandato penal" del proceso penal de adultos (que guarda similitudes con el procedimiento monitorio del CPP) en causas penales de adolescentes; por ello, no debe extrañar que desde

\footnotetext{
${ }^{126}$ Resolución no 3136-96 de 28 de junio de 1996, citada por Gary Amador. Véase AMADOR, “Algunos problemas", cit. nota $n^{\circ} 78$, p. 123.

${ }^{127}$ Véase AMADOR, “Algunos problemas”, cit. nota no 78, p. 122.

128 MERTENS, Andreas, Schnell oder gut? Die Bedeutung des Beschleunigungsgrundsatzes im Jugendstrafverfahren, Frankfurt: Peter Lang, 2003, p. 157.

129 Este fin es enfatizado especialmente en la entrevista ofrecida por Ulrich Eisenberg, así como en EISENBERG, Jugendgerichtsgesetz, cit. nota $n^{\circ} 15, \S 55$ número marginal 36.

${ }^{130}$ Como lo pone especialmente de relieve MERTENS, Schnell oder gut?, cit. nota $\mathrm{n}^{\circ} 128$.

${ }^{131}$ KUHN, Thomas, Verfahrensfairneß im Jugendstrafrecht. Das deutsche Recht und das Recht der USA im Vergleich, Munich: VVF, 1996, p. 135.

132 Así lo destaca, en su entrevista, Frieder Dünkel.
} 
Polít. crim. Vol. 7, № 13 (Julio 2012), Art. 1, pp. 1 - 73.

[http://www.politicacriminal.cl/Vol_07/n_13/Vol7N13A1.pdf]

los años noventa la duración de los procesos penales de adolescentes ha venido incrementándose. ${ }^{133}$

Se puede observar que la idea del juzgamiento en un plazo razonable es recogida en todos los países objeto de nuestra investigación con especial fuerza. Con todo, se puede apreciar que la justificación detrás de los mecanismos legales específicos y las decisiones jurisprudenciales citadas mezcla ideas propias de la noción de derecho fundamental que se encuentra detrás de la garantía en estudio con nociones propias de las consecuencias procesales que tiene la especialidad del procedimiento juvenil que no necesariamente están pensadas en lógica de garantías en su favor (las que analizaremos a propósito del próximo eje). Esta tensión de objetivos debilita en nuestra opinión el asentamiento de esta garantía.

\subsection{Mayores Resguardos al Derecho de Defensa}

Otra de las garantías bases del debido proceso general y en el que hemos visto la legislación internacional exige reforzamiento en favor de los jóvenes está constituida por el derecho de defensa. Como ya señalamos en el trabajo que sirve de base a este estudio, el derecho de defensa es uno de los componentes del debido proceso de mayor complejidad en relación a los elementos que lo integran. ${ }^{134}$ A continuación, revisaremos cómo han sido recogidas en las legislaciones en estudio las tres principales manifestaciones del derecho de defensa en donde identificamos existían exigencias especiales en el derecho internacional.

\subsubsection{Derecho a la Información Directa y sin Demora de los Cargos}

El elemento base sobre el cual se construye el derecho de defensa es el conocimiento oportuno de los cargos que se imputan a la persona objeto de persecución penal de manera tal que, a partir de ese conocimiento, pueda desarrollar actividades conducentes a la construcción de su defensa. Sin información de cargos no hay posibilidad de desarrollar una estrategia de defensa efectiva. Es por ello que la legislación internacional ha exigido que esta información se realice en forma temprana y, especialmente, que la comunicación de los cargos se haga de una manera que sea comprensible en relación al nivel de desarrollo y madurez del joven imputado. ${ }^{135}$

De las cuatro legislaciones en estudio la que regula con mayor precisión este tema pareciera ser la LO 5/2000 de España. En efecto, en ella se contienen diversas disposiciones que se hacen cargo del tema. En primer lugar, es posible mencionar al artículo 17.1 que, a propósito de la detención, establece la obligación de las autoridades y funcionarios respectivos de informarle de manera "inmediata" al joven detenido de los hechos que se le imputan "en un lenguaje claro y comprensible". ${ }^{136}$ Se puede apreciar que esta disposición se hace cargo de los dos aspectos centrales exigidos por la legislación internacional en la materia. Con todo, sólo resuelve con claridad la situación de los jóvenes detenidos y no de

\footnotetext{
${ }^{133}$ MERTENS, Schnell oder gut?, cit. nota $\mathrm{n}^{\circ} 128$, pp. 155 y 32 y ss.

${ }^{134}$ Véase DUCE, cit. nota ${ }^{\circ} 1$, pp. 95 y 96.

${ }^{135}$ Ídem, pp. 97-98.

${ }^{136}$ La disposición también exige que se le informe del motivo de su detención y demás derechos procesales de conformidad al artículo 520 de la Ley de Enjuiciamiento Criminal. No abordaremos estas otras informaciones para no salir de nuestro tema nuclear en este párrafo.
} 
DUCE, Mauricio; COUSO, Jaime. "El derecho a un juzgamiento especializado de los jóvenes infractores en el derecho comparado".

los casos en que las investigaciones han sido llevadas adelante sin detención. Para esos casos, el artículo 22, referido a la incoación del expediente que debe hacer el Ministerio Público cuando toma conocimiento de hechos que son constitutivos de delitos, establece el derecho del joven de ser informado inmediatamente de los derechos que le asisten (art. 22.1 a).

La regla del artículo 22.1 a) ha presentado algunos problemas interpretativos que podrían afectar la sustancia del derecho a ser informado del joven. La primera tiene que ver con la autoridad o funcionario que tiene el deber de entregarle la información. El artículo en análisis establece que este deber puede ser cumplido tanto por el juez, el Ministerio fiscal o el agente de la policía. No obstante esto, la doctrina ha entendido, en nuestra opinión correctamente, que quien por regla general debe hacerlo es el Ministerio Fiscal, lo que asegura la rapidez en la entrega de la información (cuando estamos en presencia de una incoación del expediente se trata de una etapa en que normalmente ni la policía ni el juez intervienen). ${ }^{137}$ Un segundo aspecto tiene que ver con los alcances de la información que debe ser entregado por la autoridad. En estricto rigor el artículo 22.1 a) establece la obligación de informar derechos y no de los cargos que se imputan al joven. No obstante esto, la interpretación que ha dado la propia fiscalía es que el decreto de incoación debe incluir también una relación sucinta del hecho imputado o el atestado policial o denuncia que haya motivado su adopción. ${ }^{138}$ Esto ha sido reforzado por la jurisprudencia. Es así como identificamos casos en los que establece que en caso de no dar a conocer los hechos objeto de la imputación los tribunales consideran que "... se ha vulnerado el derecho de defensa de las menores afectadas y las exigencias propias del principio acusatorio, aplicable a la fase de instrucción, entre las que se encuentra en que las menores conozcan los hechos por los que se le incoan el expediente". ${ }^{139}$ No obstante esto, la jurisprudencia pareciera también ser tener un nivel de flexibilidad respecto de los contenidos mínimos que deben informarse para efectos de dar por cumplido este derecho en la medida que el joven efectivamente haya estado en conocimiento y comprensión de la imputación. ${ }^{140}$

\footnotetext{
${ }^{137}$ ORNOSA FERNÁNDEZ, Derecho, cit. nota no 32, p. 308.

138 Véase, Circular de la Fiscalía General del Estado núm. 1/2000 de 18 de diciembre, sobre los criterios de aplicación de la L.O. 5/2000.

${ }^{139}$ Véase Sentencia de la Audiencia Provincial de Sevilla $n^{\circ}$ 560/2006 de 15 de diciembre de 2006, considerando cuarto.

${ }^{140}$ Véase Sentencia de la Audiencia Provincial de Sevilla no 467/2007 de 16 de octubre de 2007, considerando tercero. En este caso la información entregada era un tanto general ya que ponía acento en la imputación normativa y no fáctica. No obstante aquello, el tribunal no dio lugar a la solicitud de nulidad de la defensa. La Audiencia provincial señaló: "Ciertamente, el relato de hechos en que consistía la imputación realizada en este expediente, no puede estimarse que sea la más adecuada, aunque al haberse utilizado un concepto jurídico de fácil comprensión general (robo con violencia o intimidación de fecha 6/04/2004), a pesar de su simplicidad, no puede justificar la nulidad del trámite de imputación, ya que, por el tiempo transcurrido, produciría un resultado desproporcionado y pernicioso para los intereses del menor, aunque sí debemos recordar al $\mathrm{M}^{\mathrm{o}}$ Fiscal el cumplimiento de la Circular citada, pues es una exigencia del principio acusatorio, ya en fase de instrucción, que "el imputado conozca los hechos por los que se incoa el expediente contra él...". Con todo, en favor de la decisión es necesario señalar que la Audiencia Provincial constata en el mismo fallo que no obstante los defectos de la información entregada al joven, éste había tenido oportunidad de participar con su defensor en diversas diligencias durante la investigación, por ejemplo en una rueda de reconocimiento, todo lo cual permite suponer que conocía con bastante precisión los hechos imputados.
} 
Polít. crim. Vol. 7, N 13 (Julio 2012), Art. 1, pp. 1 - 73. [http://www.politicacriminal.cl/Vol_07/n_13/Vol7N13A1.pdf]

La legislación española pone un especial énfasis en la idea que la información que se entregue de parte de las diversas autoridades y funcionarios al joven imputado deba ser clara. Esto lleva a que sea un tema que se repita no sólo como una exigencia de la comunicación de la imputación sino que en otros momentos procesales posteriores. Así, el artículo 36.1 de la LO 5/2000, referido a la audiencia de juicio, establece que ésta se inicia con la información, que en lenguaje comprensible y adaptado a su edad, debe entregarle el secretario del tribunal, respecto de los hechos de la causa (además de las acusaciones en su contra). El artículo 39.2, referido a la sentencia, señala en su numeral 2 que "El juez, al redactar la sentencia, procurará expresar sus razonamientos en un lenguaje claro y comprensible para la edad del menor". Se trata, en todo caso, de normas cuyo cumplimiento adecuado es difícil de identificar sin una observación directa de las prácticas concretas.

En el caso de los Estados Unidos, el derecho de los jóvenes de ser informados tempranamente de los cargos que se le imputan se encuentra recogido en la actualidad en la mayoría de las legislaciones estatales. ${ }^{141}$ El hito principal por medio del cual se entregó amplio reconocimiento a esta garantía fue el caso Gault. En su decisión, la Corte Suprema de los Estados Unidos identificó en forma expresa a esta garantía como uno de los elementos mínimos para cumplir con los requerimientos del debido proceso haciéndose cargo de la forma en que debe hacerse la comunicación, su temporalidad y su contenido.

En relación a la forma, la Corte sostuvo que el niño y sus padres o guardianes debían ser notificados por escrito. Respecto a la temporalidad, la Corte señaló que "La comunicación, para cumplir con las exigencias del debido proceso, debe ser realizada con suficiente anticipación de la audiencia judicial de manera de entregar una razonable posibilidad de prepararse..." y que "...la comunicación escrita debe ser realizada al momento más temprano que sea posible, en todo caso con la anticipación suficiente para permitir su preparación". ${ }^{142}$ Para entender cómo se articula este elemento es indispensable tener presente que, a diferencia de cómo opera la mayoría de los modelos continentales, en los Estados Unidos la intervención de los fiscales se produce cuando la policía tiene bien avanzada la investigación en contra del imputado. Por lo mismo, la intervención más formal del sistema se producirá a partir de la solicitud que el fiscal realice de una audiencia lo que no coincide necesariamente con los momentos iniciales de la persecución. De esta forma, las legislaciones estatales regulan diversos plazos mínimos entre la notificación y la realización de la audiencia. ${ }^{143}$ Finalmente, la Corte también se hizo cargo de la especificidad requerida por la comunicación para cumplir con su propósito de garantía. Señaló que la comunicación debía contener "...la conducta imputada con especificidad" y que ella debía incluir "...el cargo específico o las alegaciones de hecho que serían consideradas en la audiencia". Este estándar ha sido recogido con variedad en la jurisprudencia estatal. Mientras en algunos Estados se pide que la comunicación satisfaga los mismos estándares que serían exigibles a la acusación (indictment) en tanto que otras

\footnotetext{
${ }^{141}$ Véase, GARDNER, Understanding, cit. nota $\mathrm{n}^{\circ} 43, \mathrm{p} .263$.

142 Párrafos de Gault citados por BREITENBACH, "Juvenile", cit. nota nº 95, párrafo 25 (la traducción es nuestra).

${ }^{143}$ Hay estados que establecen un mínimo de 24 horas, en tanto otros que fijan plazos mayores como cinco o diez días. Véase GARDNER, Understanding, cit. nota nº 43, p. 263.
} 
DUCE, Mauricio; COUSO, Jaime. "El derecho a un juzgamiento especializado de los jóvenes infractores en el derecho comparado".

limitan las exigencias formales en la medida en que la comunicación entregue detalles de los hechos que permitan informan sobre la naturaleza de la infracción y se le entregue de información adecuada para preparar su defensa. ${ }^{144}$

La legislación de Costa Rica no establece reglas específicas en su LJPJ acerca del derecho del joven a ser informado directamente y sin demora de los cargos que se le imputan. Con todo, la doctrina especializada en materia juvenil entiende que su vigencia se deriva del derecho a la inviolabilidad de la defensa. ${ }^{145}$ De otra parte, debe recordarse que el artículo 10 de la LJPJ hace aplicable en forma directa las garantías del debido proceso establecidas en los tratados internacionales y las establecidas en la legislación procesal de adultos. En esta última materia, tanto la doctrina como la jurisprudencia de Costa Rica, han reconocido que el derecho de conocer los hechos que se imputan a una persona desde los momentos iniciales de la persecución penal constituye un elemento clave del derecho de defensa. ${ }^{146}$ Desde esa perspectiva se trata de un derecho indiscutiblemente reconocido también en favor de los jóvenes. Con todo, la falta de una normativa especial en la materia hace que los alcances de esta garantía no se perfilen con diferencias explícitas que recojan la especialidad del sistema juvenil que parece exigir la legislación internacional en la materia.

La legislación alemana casi no contempla normas especiales sobre este derecho del adolescente. Las normas que rigen son las del proceso penal de adultos, a saber: el $\S 136$, de la StPO, que establecen el deber de informar al imputado, en la primera ocasión en que se le tome declaración, sobre los hechos que se le imputan y las respectivas disposiciones penales que vienen a colación, así como sobre su derecho a guardar silencio y a contar con un defensor; y el $\S 201$ de la StPO, que regula la comunicación, al acusado, del escrito de acusación. De hecho, en los comentarios doctrinales de la JGG se destaca que la aplicación de los preceptos generales (en particular, el $\S 136$ de la StPO) representa un límite garantista a los intereses educativos del proceso penal de adolescentes, en el sentido de que la desformalización de las audiencias, que es propia de la justicia penal de adolescentes, encuentra un límite, cuando se trata de su primera declaración, en el respeto de los derechos generales de todo imputado, a conocer claramente los cargos que se le formulan, etc. ${ }^{147} \mathrm{La}$ única referencia especial en la JGG se encuentra en el $\S 46$, y establece que al darse a conocer el escrito de acusación por parte del fiscal al adolescente, debe procurarse hacerlo de tal modo de no perjudicar su educación, lo que también se ha entendido como un llamado a que dicha comunicación se haga de una forma comprensible para el adolescente, conforme a su edad. ${ }^{148}$ Una peculiaridad adicional, que resulta de la relación sistemática del $\S 67$ de la JGG con las diversas reglas procesales aplicables a las causas de adolescentes, es que no sólo el defensor, sino también la persona encargada de la educación del adolescente, pueden acompañarlo en sus comparecencias, de modo que pueden servirle de apoyo para la comprensión de los cargos que se le notifican o de la acusación que se le comunica.

\footnotetext{
144 Ídem.

${ }^{145}$ En este sentido véase AMADOR, La Detención, cit. nota n ${ }^{\circ}$ 74, p. 195

146 Véase LLOBET, Javier, Derecho Procesal Penal: Garantías Procesales (segunda parte), San José: Editorial Jurídica Continental, 2007, p. 38 y 39.

${ }^{147}$ EISENBERG, Jugendgerichtsgesetz, cit. nota $\mathrm{n}^{\circ} 15, \S 44$ número marginal 10.

${ }^{148}$ LAUBENTHAL / BAIER, Jugendstrafrecht. cit. nota $\mathrm{n}^{\circ} 11, \mathrm{p} .131$.
} 
Polít. crim. Vol. 7, N 13 (Julio 2012), Art. 1, pp. 1 - 73.

[http://www.politicacriminal.cl/Vol_07/n_13/Vol7N13A1.pdf]

\subsubsection{Derecho a Ser Escuchado en Forma Directa}

Un elemento central del derecho de defensa establecido en favor de los jóvenes objeto de una imputación penal es el derecho que tienen a ser escuchado por las diversas autoridades y en las diversas etapas de tramitación de los procesos penales. En esta dirección, según tuvimos oportunidad de analizar, la CDN contempla exigencias fuertes respecto a la participación de los niños en el proceso, especialmente enfatizando la posibilidad que intervengan en forma directa dando su opinión respecto a las decisiones que lo puedan afectar, lo cual supone como mínimo contar con información que permita a los jóvenes expresar su punto de vista. ${ }^{149}$ La importancia de este derecho ha sido recientemente enfatizada por el Comité de Derechos del Niño por medio de la elaboración de una nueva observación general referida específicamente al tema del derecho del niño a ser oído. ${ }^{150} \mathrm{En}$ la sección relativa al derecho a ser escuchado en procedimientos penales judiciales, se contienen recomendaciones similares a las ya identificadas en el trabajo que sirve de base del presente. ${ }^{151}$

De las legislaciones en estudio, pareciera que la LO 5/2000 de España es que la manifiesta mayor preocupación por hacerse cargo de las características especiales de este derecho. Así, en diversas secciones de la ley se manifiesta la especial preocupación del legislador que el joven sea escuchado (por ejemplo artículos 19, 32, 36, 37.2, 56.2, 58.2 y 60). ${ }^{152}$ Tal vez si la norma más explícita y genérica es la contenida en el artículo 22.1 letra d) que establece que desde el momento de incoación del expediente el joven tiene derecho a ser oído por el juez o tribunal antes de adoptar cualquier resolución que le concierna personalmente. Se trata de una norma bastante amplia, pero que presenta el problema que para su vigencia aparentemente requiere que el propio joven haga un ejercicio activo de su derecho. Sin que exista un mecanismo concreto de información específica para cada decisión podría tratarse más que de un derecho, de una orientación programática. En este sentido, es interesante una decisión del Tribunal Constitucional en una materia que podría considerarse análoga. En efecto, en un caso sobre el derecho a la última palabra de la defensa que veremos con más detalle, el Tribunal Constitucional señaló que "...el hecho que no se solicite por el propio recurrente o por su asistencia letrada no empece que el órgano judicial tenga el deber de ofrecer esta garantía..." $"$.153 . Si esta lógica se extiende al derecho a ser escuchado en general, éste impone una carga de comunicación a los tribunales que permite hacerlo efectivo.

En el contexto Español, nuestra investigación nos permitió encontrar jurisprudencia relevante sólo en una de las manifestaciones específicas del derecho en análisis en la legislación de dicho país: el derecho del acusado a la última palabra contenido en el artículo 37.2 que regula la dinámica de la audiencia de juicio. Dicho precepto establece que antes de finalizar la audiencia de juicio pero luego de producida la prueba y la participación de todos los intervinientes, el "juez oirá al menor". A partir de ese momento el caso queda en

\footnotetext{
${ }^{149}$ Véase DUCE, cit. nota ${ }^{\circ} 1$, pp. 98 y 99.

${ }^{150}$ Véase Comité de Derechos del Niño, Observación General no 12 "El Derecho del Niño a Ser Escuchado", Julio de 2009.

${ }^{151}$ Véase párrafos 57 a 64 referidos tanto al niño infractor como al niño víctima y testigo.

${ }^{152}$ En este mismo sentido ORNOSA FERNÁNDEZ, Derecho, cit. nota $\mathrm{n}^{\mathrm{o}} 32$, p. 312.

${ }^{153}$ Sentencia del Tribunal Constitucional no 13/2006 de 16 de enero de 2006, párrafo II.5.
} 
DUCE, Mauricio; COUSO, Jaime. "El derecho a un juzgamiento especializado de los jóvenes infractores en el derecho comparado".

condición de ser resuelto. El Tribunal Constitucional, en la sentencia que citamos en forma reciente, tuvo oportunidad de pronunciarse sobre este derecho. En lo que nos parece más relevante, el Tribunal establece que se trata de una garantía que favorece a los jóvenes por expreso reconocimiento de la LO 5/2000 y no solo por derivación de las reglas generales contenidas en la ley de Enjuiciamiento Criminal. ${ }^{154}$ Además, se reconoce específicamente el hecho que esta garantía forma parte del derecho de defensa y, particularmente, al derecho de defensa personal. ${ }^{155}$ En una buena parte de su desarrollo el Tribunal justifica la función que este derecho cumple, pero especialmente tomando en consideración las reglas establecidas en la legislación española sobre la materia.

La regulación descrita contrasta con lo establecido en la LJPJ de Costa Rica. En efecto, el artículo 24 de la misma contempla el derecho de los jóvenes a ser oídos bajo la idea del principio contradictorio. Sin embargo, la misma disposición señala luego este derecho está garantizado por la intervención de un defensor y del Ministerio Público dentro del proceso. Nos parece que la confusión se produce precisamente por tratar sistemáticamente el derecho a ser oído exclusivamente como parte del derecho a la contradictoriedad y no de la defensa personal. Esto permitiría que por la participación del defensor en las distintas actuaciones se entienda satisfecha la garantía sin necesidad de escuchar al joven imputado. $^{156}$

La legislación alemana, por último, establece la posibilidad o el deber de escuchar al adolescente de forma algo fragmentaria. Así, por ejemplo, conforme al $\S 44$ de la JGG, el fiscal o el presidente del tribunal juvenil deberían escuchar personalmente al adolescente, antes de que se formule la acusación, cuando es de esperar la imposición de una pena juvenil (privativa de libertad), audiencia que apuntaría a ofrecer al fiscal o los jueces la oportunidad de hacerse "una impresión" personal sobre el adolescente, incluso sobre su grado de desarrollo, en una atmósfera algo más "relajada" en la que el adolescente pueda expresarse de forma más desinhibida. ${ }^{157} \mathrm{La}$ disposición, sin embargo, tiene muy escasa aplicación, por no estar formulada en términos categóricos. ${ }^{158}$ Otras disposiciones particulares establecen la audiencia del adolescente, por ejemplo, cuando se decide suspender la pena juvenil (privativa de libertad) a prueba y se determinan la condiciones de tal suspensión ( $\S 557$ y 58 de la JGG). Con todo, de la garantía constitucional establecida en el Art. 103.1 de la Constitución Federal Alemana se desprende, también para el proceso penal de adolescentes, un derecho del adolescente (que también es un deber, conforme a la legislación procesal penal común, aplicable también a la JGG) a estar presente en el juicio,

\footnotetext{
154 Ídem párrafo II.4.

${ }^{155}$ Ibíd.

156 Aparentemente esta falta de tratamiento autónomo de este derecho produce también una cierta despreocupación doctrinaria sobre su existencia y desarrollo. Así, en autores que desarrollan con algún detalle el derecho de defensa no se refieren al derecho a ser escuchado personalmente como una manifestación relevante del mismo. Véase ARMIJO, "Las alternativas", cit. nota n 82, pp. 253 a 272 y DALL'ANESSE, Francisco, "El Proceso Penal Juvenil en Costarricense: Principios y Alternativas a la Justicia", en De la Arbitrariedad a la Justicia: Adolescentes y Responsabilidad Penal en Costa Rica, UNICEF, 2000, pp. 299 a 309.

${ }^{157}$ EISENBERG, Jugendgerichtsgesetz, cit. nota $n^{\circ} 15, \S 44$ número marginal 4.

${ }^{158}$ Ibíd, § 44 número marginal 6.
} 
Polít. crim. Vol. 7, N 13 (Julio 2012), Art. 1, pp. 1 - 73. [http://www.politicacriminal.cl/Vol_07/n_13/Vol7N13A1.pdf]

y el derecho a ser oído sobre todas las cuestiones relevantes para la decisión. ${ }^{159}$ La JGG debe interpretarse y aplicarse en concordancia con esa garantía, si bien alguna tensión surge de la protección de los "intereses educativos" del adolescente, que explican la limitación al derecho a estar presente en el juicio, establecida por el $\S 51$ de la ley, disposición que permite al presidente del tribunal hacer salir al adolescente cuando su presencia podría perjudicar su educación, regulación que despierta críticas y demandas de una interpretación y aplicación restrictiva. ${ }^{160}$

Las legislaciones analizadas parecieran recoger, con distinta intensidad, la necesidad de contemplar mecanismos que permitan la posibilidad al joven de manifestar su opinión y la posibilidad de ser oído en diversos momentos por los jueces. Con todo, pudimos apreciar una cierta constante en el hecho que esos mecanismos no cuentan con una práctica de los tribunales que promueva de manera activa que la posibilidad de intervenir se transforme en una actividad cotidiana y cierta de dichos sistemas. En consecuencia, pareciera que la sola regulación de la posibilidad de ser oídos no basta para asegurar el ejercicio de este derecho en la práctica sino es acompañado de otros elementos que promuevan su uso activo.

\subsubsection{Derecho a la Asistencia Apropiada}

El ejercicio personal del derecho de defensa por parte del joven y el cumplimiento del derecho a ser oído normalmente no bastarán por sí solos para asegurar una defensa efectiva de los niños y jóvenes imputados. Para estos efectos, un derecho adicional contemplado en la legislación internacional es el de contar con una asistencia apropiada. Como tuvimos oportunidad de señalar, la legislación internacional, en especial la CDN, permite que esa asistencia sea prestada por otros profesionales (por ejemplo asistentes sociales) en la medida que sea "apropiada". Además, vimos que para satisfacerse adecuadamente esta garantía requería que la asistencia fuera prestada en forma oportuna (desde los momentos iniciales de la persecución penal), gratuita y permanente (es decir durante todos las etapas del proceso). ${ }^{161}$

La revisión de las legislaciones en estudio nos lleva a concluir que se trata en general de un derecho que encuentra un nivel fuerte de protección, incluso con estándares superiores a los establecidos en el ámbito internacional. Por ejemplo, este pareciera claramente el caso del sistema de Costa Rica. En efecto, el derecho del joven a una asistencia apropiada es comprendido en el sistema de dicho país como el derecho a contar con asistencia letrada (artículos 22 y 37 de la LJPJ), ello precisamente en la idea de contar con profesionales más cualificados en la asesoría de los jóvenes. ${ }^{162}$ Se entiende, además, que ese derecho es

\footnotetext{
${ }^{159}$ KUHN, Verfahrensfairneß, cit. nota ${ }^{\circ} 131$, p. 91.

${ }^{160}$ Así, en la entrevista ofrecida por Ulrich Eisenberg; v. también, EISENBERG, Jugendgerichtsgesetz, cit. nota $\mathrm{n}^{\circ} 15, \S 51$ número marginal 8; y LAUBENTHAL / BAIER, Jugendstrafrecht. cit. nota $\mathrm{n}^{\circ} 11$, p. 137.

${ }^{161}$ DUCE, cit. nota $\mathrm{n}^{\mathrm{o}} 1$, pp. 99 y 100.

${ }^{162}$ En este sentido se señala que "La defensa no la puede ejercer el padre, la madre, el trabajador social, o el psicólogo, porque se trata de un proceso penal, con posibles connotaciones negativas (restricción de derechos) de ahí que es el abogado quien está capacitado para esta función". Véase TIFFER, "La Ley de Justicia", cit. nota $\mathrm{n}^{\mathrm{o}} 26$, p. 95 . Desde otro punto de vista se sostiene que sólo a través de la asistencia letrada se cumple el objetivo de "... aumentar o acrecentar las posibilidades de defensa del adolescente acusado en todas las fases
} 
DUCE, Mauricio; COUSO, Jaime. "El derecho a un juzgamiento especializado de los jóvenes infractores en el derecho comparado".

universal, es decir, todos los jóvenes lo tienen si hacer distinciones acerca de la relevancia o complejidad del caso. ${ }^{163}$

El estudio detallado de las normas que establecen el derecho a la asistencia apropiada así como de la doctrina de Costa Rica permite observar que este derecho se hace operativo en la práctica cumpliendo las exigencias de oportunidad, gratuidad y permanencia establecidas en la legislación internacional. Sobre la oportunidad, tanto el artículo 22 como el 37 de la LJPJ establecen que el derecho a ser asistido por un defensor se tiene "desde el inicio de la investigación policial" (art. 22) y desde "el inicio de la investigación" (art. 37). La doctrina entiende que esto se refiere al primer momento de la persecución penal. ${ }^{164}$ Las mismas disposiciones citadas también resuelven la exigencia de la "permanencia" de la asistencia apropiada al establecer que ella se extiende "durante todo el proceso" (art. 37) y hasta que los jóvenes "cumplan con la sanción impuesta" (art. 22). Es decir, en donde se asegura la presencia del defensor no sólo a aquellas etapas procesales más tradicionales sino que se amplía a todo el período de ejecución de las consecuencias o sanciones establecidas por el sistema. Finalmente, la gratuidad es resuelta normativamente en el inciso segundo del artículo 37 de la LJPJ que señala que el Estado brindará un defensor público a los jóvenes que no cuentan con recursos económicos. Dicha norma se encuentra complementada por el artículo 4 del Código de la Niñez y Adolescencia de 1998 que establece que es obligación del Estado adoptar las medidas (administrativas, legislativas, presupuestarias y de cualquier índole) para garantizar la plena efectividad de los derechos fundamentales de los menores de edad. ${ }^{165}$ En la práctica, este derecho se hace efectivo por la existencia de un sistema de defensa pública, especializado de carácter estatal ${ }^{166}$ que atiende a un porcentaje mayoritario de las defensas del sistema. ${ }^{167}$

En España se presenta una situación similar a la descrita en Costa Rica. En general, se entiende que el derecho a contar con asistencia apropiada se satisface cuando el joven cuenta con asistencia letrada. Esta exigencia es de mayor amplitud que tratándose de los adultos ya que en casos de simples faltas estos podrían asistir a juicio sin contar con un abogado, en tanto en los procesos seguidos contra jóvenes -sin distinción (faltas o delitos)se debe contar con asistencia de un letrado. ${ }^{168}$ Tal vez si una particularidad interesante de la legislación española que la diferencia con la LJPJ de Costa Rica es que la regulación de este derecho no se agota sólo con la consagración de la asistencia letrada. En efecto, el artículo 22.1 e) amplía este derecho a contar con "asistencia afectiva y psicológica en cualquier estado y grado del procedimiento", lo que involucra la asistencia de los padres u

del proceso..." frente a la situación de desigualdad de poder en la que se encuentran en los procesos penales. Véase ROJAS, cit. nota ${ }^{\circ} 10$, p. 353.

${ }^{163}$ Véase TIFFER, "La Ley de Justicia", cit. nota n 26, p. 96. Véase también Alejandro Rojas quien sostiene que ello es consecuencia que "...nuestro sistema de justicia penal juvenil adoptó la idea de la defensa necesaria y no voluntaria, auto obligándose a no realizar distinciones referidas a determinada situación del adolescente procesado o de la supuesta sencillez del caso concreto" ROJAS, cit. nota ${ }^{\circ} 10$, p. 361.

164 ARMIJO, "Las alternativas", cit. nota ${ }^{\circ}$ 82, p. 258.

${ }^{165}$ Véase ROJAS, cit. nota ${ }^{\circ} 10$, p. 361.

${ }^{166}$ Véase ARMIJO, "Las alternativas", cit. nota nº 82, p. 259 a 262.

${ }^{167}$ Rojas estima que el sistema de defensa pública cubre el $90 \%$ de las defensas de adolescentes sometidos al proceso penal juvenil. Véase ROJAS, cit. nota $n^{\circ} 10$, p. 361.

${ }^{168}$ Véase entrevista a Francisco Manuel García Ingelmo, cit, nota ${ }^{\circ} 9$. 
Polit. crim. Vol. 7, No 13 (Julio 2012), Art. 1, pp. 1 - 73.

[http://www.politicacriminal.cl/Vol_07/n_13/Vol7N13A1.pdf]

otra persona que indique el joven y la participación de psicólogos que forman parte de los equipos técnicos de tribunales, todos en apoyo del imputado. ${ }^{169}$

El análisis de las reglas de la LO 5/2000, la doctrina y jurisprudencia española también permiten concluir que en dicho sistema el derecho a la asistencia apropiada se cumple respetando exigencias de oportunidad, permanencia y gratuidad. ${ }^{170}$ En materia de oportunidad, diversas normas dejan en claro que la idea del legislador es permitir la intervención del letrado desde los primeros momentos de la persecución penal. Esta situación se ha visto reforzada con la reforma introducida en la LO 8/2006 que esclareció la intervención del letrado aún antes de la toma de declaración que puede hacer la policía o el fiscal luego de practicada su detención. ${ }^{171}$ En efecto, el artículo 17.2 regula que el joven detenido tiene derecho a que su declaración se lleve en presencia de su abogado. Establece, además, que el joven tiene derecho entrevistarse con el letrado en forma reservada con anterioridad y al término de la declaración. Complementa a lo anterior el artículo 22.1 a) que establece el derecho del joven a designar abogado desde el momento de incoación del expediente y a entrevistarse con él antes de prestar declaración. Se trata de una norma que permite la intervención temprana del letrado en casos en que podrían iniciarse sin detención y que, por lo mismo, complementa la disposición del artículo 17. Además, el artículo 22.2 establece la obligación del fiscal, al comunicar la incoación del expediente, de requerir al joven y a sus representantes legales la designación de un defensor dentro del plazo de tres días. ${ }^{172}$ La jurisprudencia ha recogido con fuerza estos mandatos anulando casos en los que la intervención del joven imputado en el proceso se produjo sin una designación temprana del defensor en los términos que señala la ley. ${ }^{173}$

En cuanto a la permanencia, de acuerdo al artículo 545 de la Ley Orgánica del Poder Judicial, la presencia del abogado defensor en todas las etapas del proceso es considerada imprescindible, entendiéndose que ello cubre desde la detención hasta la ejecución de la pena. $^{174}$

Finalmente, respecto a la gratuidad, el artículo 22.2 de la LO 5/2000 señala que en caso que el joven no designe defensor dentro del plazo de tres días en que se la ha notificado la

\footnotetext{
${ }^{169}$ Véase ORNOSA FERNÁNDEZ, Derecho, cit. nota n ${ }^{\circ} 32$, p. 313.

${ }^{170}$ Véase por ejemplo Vicente Peláez quien sostiene, al referirse a la implementación de la LO 5/2000 que "Es en ese contexto donde se encuadra la intervención del Abogado, que, no cabe duda, ha significado un gran avance, al haber logrado establecer el ejercicio pleno del derecho de defensa en el ámbito de la justicia de menores de reforma, cumpliéndose de una vez por todas las exigencias que al respecto recoge la Convención sobre los Derechos del Niño...". PELÁEZ, Vicente, "La Intervención del Abogado en la Justicia de Menores en España", en Los Derechos de los Niños: Perspectivas Sociales Políticas Jurídicas y Filosóficas, Madrid: Editorial Dykinson, 2007, p. 113.

${ }^{171}$ DÍAZ / LUACEZ, cit. nota n ${ }^{\circ} 87$, p. 354.

${ }^{172}$ La redacción anterior a la reforma de 2006 establecía que la obligación de notificación era del secretario del Juzgado de menores lo que hacía que la norma no cumpliera su finalidad de protección. Por lo mismo era fuertemente criticada por la doctrina española. Véase DOLZ, Manuel Jesús, "La Reforma del Derecho Penal de Menores", en Estudios sobre la Responsabilidad Penal del Menor, Castellón de la Plana-España: Universita Jaume, 2006, p. 240.

${ }^{173}$ Véase por ejemplo la Sentencia Audiencia Provincial de Jaén no $125 / 2001$ de 10 de octubre de 2001 y de la Audiencia Provincial de las Palmas n 219/2001 de 18 de septiembre de 2001.

${ }^{174}$ Véase PELÁEZ, cit. nota ${ }^{\circ} 170$, p. 115.
} 
DUCE, Mauricio; COUSO, Jaime. "El derecho a un juzgamiento especializado de los jóvenes infractores en el derecho comparado".

incoación del expediente, se le nombrará a un abogado de oficio del turno de especialistas del Colegio de Abogados. Ello se complementa con las reglas de la Ley de Asistencia Jurídica Gratuita que son aplicables al proceso penal juvenil y aseguran la gratuidad del servicio. ${ }^{175}$

En la JGG alemana también se ha ampliado la garantía de la defensa letrada, en comparación con la extensión que tiene en el proceso penal de adultos, pero no tiene los alcances generales que se le concede en Costa Rica y España. Así, si bien todo imputado tiene teóricamente derecho a designar un defensor de su elección en cualquier etapa del procedimiento (desde antes de que se inicie la etapa de investigación hasta después de concluida la ejecución de la sanción ${ }^{176}$ ), ello no asegura, en la mayoría de los casos, el acceso a la defensa (ya en primer lugar, por la imposibilidad de solventar los costos, cuya regulación no difiere de la del proceso penal de adultos), que sólo queda garantizada en los casos de defensa obligatoria, establecidos, no con alcance general, sino sólo para determinados supuestos, que, con todo, son bastante amplios. Así, la defensa está asegurada (de forma gratuita), en concreto, en los casos de defensa obligatoria establecidos por el $\S$ 140 de la StPO - referidos, entre otros, a personas imputadas por delitos graves o especialmente complejos, sometidas a prisión preventiva, y personas que no pueden defenderse a sí mismas - y en los casos adicionales contemplados por el $\S 68$ de la JGG, referidos al adolescente cuyo apoderado o representante legal ha sido privado de sus derechos parentales o de representación, y al adolescente que ha sido internado para la preparación de una pericia sobre su estado de desarrollo o, en general, ha sido objeto de internación provisoria.

La jurisprudencia alemana tiende a interpretar la causal de "gravedad del delito" (o "de la culpabilidad") en función de la posibilidad de que por tal delito se imponga al adolescente una pena juvenil (privativa de libertad). ${ }^{177}$ La causal que más discusión parece generar en la jurisprudencia es la de que el inculpado "no pueda defenderse por sí mismo", cuestión que ha tendido a afirmarse en casos de adolescentes inmigrantes con bajo dominio del idioma, o de adolescentes con un "nivel de formación [apenas] elemental", o con "inteligencia disminuida", así como, en ciertas ocasiones, para adolescentes con problemas de aprendizaje y especialmente, con problemas de dependencia de las drogas, y, en caso de adolescentes co-imputados, cuando algunos de ellos ya tienen defensor (lo que podría perjudicar al que no lo tiene), ${ }^{178}$ lo que ha llevado a afirmar que la mayor parte de los adolescentes imputados deberían gozar de defensa obligatoria. ${ }^{179}$

\footnotetext{
${ }^{175}$ En este sentido véase GÓMEZ COLOMER, Juan Luis, “Tuición Procesal Penal de Menores y Jóvenes”, en Justicia Penal de Menores y Jóvenes, Valencia: Tirant lo Blanch, 2002, p. 186.

${ }^{176}$ LAUBENTHAL / BAIER, Jugendstrafrecht. cit. nota $\mathrm{n}^{\circ} 11, \mathrm{p} .93$.

${ }^{177}$ EISENBERG, Jugendgerichtsgesetz, cit. nota $n^{\circ} 15, \S 68$ número marginal 24. En el mismo sentido, la información aportada por Frieder Dünkel, en su entrevista, haciendo referencia a la jurisprudencia de los tribunales superiores de Colonia y de otros landes, que califican de especialmente "complejos", y por tanto, necesitados de defensa obligatoria, los casos en que hay riesgo de imposición de una pena juvenil (privativa de libertad).

${ }^{178}$ EISENBERG, Jugendgerichtsgesetz, cit. nota $\mathrm{n}^{\mathrm{o}} 15, \S 68$ número marginal 27.

${ }^{179}$ KUHN, Verfahrensfairne $\beta$, cit. nota ${ }^{\circ} 131$, p. 126.
} 
Polít. crim. Vol. 7, № 13 (Julio 2012), Art. 1, pp. 1 - 73. [http://www.politicacriminal.cl/Vol_07/n_13/Vol7N13A1.pdf]

Por lo que respecta a la permanencia de la defensa obligatoria, está asegurada, en principio, hasta que la sentencia definitiva quede firme, pero también se extiende a las decisiones que pueden alterar el contenido de dicha sentencia, en sede de control judicial de la ejecución, particularmente en lo que respecta a la defensa obligatoria establecida en atención a la "gravedad de la culpabilidad" y en atención la "incapacidad [del adolescente] de defenderse a sí mismo". ${ }^{180}$ Desde el punto de vista de la oportunidad de la defensa obligatoria, en cambio, Eisenberg destaca, críticamente, que si bien es perfectamente posible designar defensor en esta etapa (por ejemplo, bajo la causal de imposibilidad de defenderse por sí mismo), rara vez se hace uso de este derecho, y que la presencia obligada del defensor sólo rige en la práctica durante el juicio oral (su ausencia es un motivo absoluto de nulidad), deficiencia que bien puede tener consecuencias durante el propio juicio, a raíz de errores cometidos en la etapa de investigación que impactan en él (peritajes y declaraciones que pueden llegar a ser empleados como prueba después). ${ }^{181}$ Dünkel confirma, por su parte, que empíricamente los adolescentes cuentan con abogado con menor frecuencia que los imputados adultos, pero destaca que la nueva regulación legal de la ejecución penal juvenil que abre importante campo a la defensa durante esta fase. ${ }^{182}$

Los defensores, en todo caso, en Alemania no tienen una exigencia especial de capacitación o especialización en Derecho penal de adolescentes y criminalidad de adolescentes. Sin embargo, la exigencia de "especialización", en el sentido de cierta disposición "educativa" en el ejercicio de su labor, puede llegar a ser problemática, cuando una defensa enérgica, más bien desarrollada en términos estrictamente contradictorios, es calificada de "confrontacional" (con el tribunal), lo que en casos aislados ha llevado a que sean excluidos por el tribunal de la defensa, bajo el pretexto de de que no son "idóneos educativamente", lo que ha sido enérgicamente criticado por la doctrina, que destaca cómo lo central en la relación defensor-adolescente es la relación de lealtad y confianza. ${ }^{183}$ De hecho, el "principio de confianza" es de especial importancia en relación con la elección del defensor. Conforme a este principio, que ha sido reconocido por la jurisprudencia del Tribunal Constitucional Federal (BVerfG), el tribunal debe dejar la elección a la decisión del imputado y, en caso necesario, darle oportunidad para informarse; conforme al $\S 142$, párrafo 1, segunda frase, de la StPO, el tribunal debe respetar la decisión del imputado si no hay importantes razones para no hacerlo. ${ }^{184}$

En los Estados Unidos, nuevamente el hito central a partir del cual se ha construido el derecho de asistencia apropiada del joven es el caso Gault. Sin perjuicio de la existencia de jurisprudencia previa en varios estados, es a partir de Gault donde la Corte Suprema toma una posición fuerte exigencia que el joven sea representado por un abogado en los casos de delinquency. ${ }^{185}$ Como puede observarse, nuevamente este derecho se articula con una exigencia más alta que la establecida en el sistema internacional ya que se considera como apropiada la asistencia cuando éste es prestada en principio por un abogado. Con todo, es

\footnotetext{
${ }^{180}$ EISENBERG, Jugendgerichtsgesetz, cit. nota $\mathrm{n}^{\circ} 15, \S 68$ número marginal 20 y $\S 83$ número marginal 9.

${ }^{181}$ EISENBERG, Jugendgerichtsgesetz, cit. nota ${ }^{\circ} 15, \S 68$ número marginal 34 a y 35.

${ }^{182}$ Entrevista a Frieder Dünkel.

${ }^{183}$ Información aportada por la entrevista a Ulrich Eisenberg.

${ }^{184}$ EISENBERG, Jugendgerichtsgesetz, cit. nota $\mathrm{n}^{\circ} 15, \S 68$ número marginal 32.

${ }^{185}$ Véase BREITENBACH, “Juvenile”, cit. nota n 95, párrafo 26.
} 
DUCE, Mauricio; COUSO, Jaime. "El derecho a un juzgamiento especializado de los jóvenes infractores en el derecho comparado".

necesario tener presente que Gault se aplica a los casos de delinquency y, por tanto, no representa una obligación universal que cubra toda comparecencia de un joven a un proceso judicial. Incluso en dichos casos, la exigencia de asistencia letrada existe en la medida que el joven vea comprometida su libertad como consecuencia del caso que se sigue en su contra. En consecuencia, el estándar del tipo de asistencia es más alto en la cualificación profesional de quien la presta, pero presenta limitaciones respecto de los jóvenes que se benefician del mismo. En esta dirección, Costa Rica y España parecen mostrar un nivel mayor de protección.

Las autoridades estatales (policías o jueces por ejemplo) deben informar al joven de su derecho a designar a un defensor desde temprano, lo cual permite que este derecho se haga efectivo de manera oportuna. Como reforzamiento de esto Gault establece que también los padres del joven deben ser notificados del mismo derecho. ${ }^{186}$

La revisión de la literatura y jurisprudencia de los Estados Unidos muestra que no existen diferencias importantes respecto a las exigencias de la permanencia (tampoco hay dudas acerca de la extensión del derecho durante todo el proceso) y gratuidad que hemos visto anteriormente, por lo que no nos detendremos en estos aspectos. Si parece más relevante consignar información acerca de la forma concreta en que los Estados implementan la decisión de Gault ya que ello da cuenta de cómo en la práctica es comprendido este derecho.

La forma en que Gault ha sido implementado en los distintos Estados presenta variaciones importantes. Así, aparentemente una minoría de Estados ha establecido la obligatoriedad de contar con un abogado ya sea durante todo el proceso (Iowa y Texas) o al menos a un asesoramiento preliminar. Es decir, el derecho de defensa letrado como obligatorio. ${ }^{187}$ La mayoría, en cambio, ha mantenido el criterio tradicional existente para adultos que permite al joven renunciar al derecho a ser asesorado por un abogado, es decir, que el derecho a defenderse personalmente es posible y válido. ${ }^{188}$ A partir de Gault se ha entendido que es posible renunciar al derecho a contar con un abogado en la medida que dicha decisión haya sido adoptada "competently and intelligently". ${ }^{189}$ Es decir, se permite la renuncia cuando el tribunal que conoce del caso puede asegurarse -debido a la edad del joven, su nivel de educación, la información que disponía y otros hechos relevantes- que éste podía tomar una decisión "inteligente" sobre su derecho. ${ }^{190}$ Básicamente, lo que se trata de evitar es que un

\footnotetext{
${ }^{186}$ La Corte Suprema, a propósito de la aplicación de la FJDA, ha tenido la oportunidad de señalar que la falta de notificación a los padres no constituye una violación de derechos que per se debiera traducirse en la anulación de un caso. Con detalle sobre este punto, véase SCHWARTZ, Allan L., "Failure to give adequate notice to juvenile's parents as ground for reversal of determination of juvenile delinquency under Federal Juvenile Delinquency Act (18 U.S.C.A. $\S \S 5031$ to 5042)", American Law Reports ALR Federal $n^{\circ} 30,475$ (publicado originalmente el año 1976).

${ }_{187}^{18}$ Véase SHEPHERD, "Still Seeking", cit. nota ${ }^{\circ} 44$.

${ }^{188}$ Véase BLUM, George, "Validity and Efficacy of Minor's Waiver of Right to Counsel-Cases Decided Since the Application of Gault", American Law Reports n' 101, 2002, párrafo 2.a.

${ }^{189}$ Véase SHEPHERD, Robert, "Juveniles' Waiver of the Right to Counsel”, Criminal Justice Magazine $n^{\circ} 1$

Vol. 13

(1998), en:

http://www.americanbar.org/publications/criminal_justice_magazine_home/crimjust_juvjus_13_1jwr.html [visitada El 16.04.2012].

${ }^{190}$ Véase BREITENBACH, “Juvenile”, cit. nota n 95, párrafo 27.
} 
Polít. crim. Vol. 7, N 13 (Julio 2012), Art. 1, pp. 1 - 73.

[http://www.politicacriminal.cl/Vol_07/n_13/Vol7N13A1.pdf]

derecho de la importancia que tiene el de asistencia apropiada pueda ser renunciado, generando perjuicio significativo al joven si es que éste no tenía competencia para tomar una decisión voluntaria, informada y con comprensión de sus consecuencias. ${ }^{191}$ Como se puede observar, se trata de un estándar bastante abierto y complejo, lo que se ha traducido en una cantidad enorme de jurisprudencia, tanto a nivel federal como local, en el que se intentan precisar situaciones en que corresponde o no admitir el desistimiento del derecho. ${ }^{192}$ También se identifican regulaciones legales que establecen exigencias o requerimientos distintos para admitir la validez de los desistimientos. Todo ello da cuenta que no obstante la renuncia al derecho de defensa letrada es común para adultos y jóvenes, en estos últimos, derivado de su estado de desarrollo y madurez, se generan reglas más estrictas que tratan de lidiar con los mayores riesgos que significa la admisión de la renuncia.

Para tener una imagen gruesa de diversos mecanismos legales y jurisprudenciales establecidos para recoger esta diferencia del joven resulta útil la identificación que hace Shepherd en donde agrupa tres categorías: (a) Estados o casos que imponen para validar el ejercicio del desistimiento que el joven sea asesorado por un abogado para la toma de su decisión; (b) Estados o casos en los que sólo se admite la validez del desistimiento luego que el joven consulte con sus padres o tutores; y, (c) Estados o casos que aceptan la renuncia caso a caso sobre la base de considerar la totalidad de las circunstancias que rodean al ejercicio de la renuncia. ${ }^{193}$

Volviendo al tema principal, a nivel federal las regulaciones principales sobre esta materia se encuentran en la FJDA, específicamente en su sección 5034 referida a las obligaciones de los jueces respecto de los jóvenes objeto de persecución federal. Así, una primera obligación del juez federal es la de asegurarse que el joven tenga representación de un abogado antes de cualquier "etapa crítica" del proceso. Se puede observar que no se trata de una garantía universal para "toda" etapa sino sólo las críticas. Ahora bien, el juez procederá a designar a un abogado si el joven, sus padres o guardianes no tienen condiciones financieras para pagar al abogado o, teniéndolas, no han designado a un abogado (en este último caso puede ordenar que se le pague al abogado una tasa razonable por su trabajo). La sección 5034 refuerza la representación del joven estableciendo que el juez debe también designar un "curador ad litem" si es que los padres o tutores del joven no están presentes o si estándolo ellos no ayudaran al joven a la preparación del juicio o hay razones para creer que sus intereses son adversos a los del joven.

\footnotetext{
${ }^{191}$ Un caso curioso de jurisprudencia se presentó a nivel federal en el Estado de California en el cual un joven imputado renunció a su derecho a defensa letrada optando por su auto representación, pero luego solicitó ser representado por su padre que no era abogado. La Corte señaló que el joven no tenía derecho a ser defendido por una persona no abogado y que, al decidir su derecho a defenderse personalmente, la ley no regulaba la posibilidad de tener a un co-defensor junto. Véase, "Right of juvenile court defendant to be represented during court proceedings by parent", American Law Reports $n^{\circ} 11,719$ (publicado originalmente en 1982)

${ }^{192}$ En este sentido recomendamos revisar a modo ejemplar el trabajo de BLUM, cit. nota $\mathrm{n}^{\circ} 188$.

${ }^{193}$ Véase SHEPHERD, “Juveniles' Waiver", cit. nota no 189, El autor señala en todo caso que no se trata de categorías que puedan distinguirse con tanta claridad y que en muchos casos se superponen unas y otras. Con más detalles también pueden verse distintas categorías de situaciones en BLUM, cit. nota $n^{\circ} 188$.
} 
DUCE, Mauricio; COUSO, Jaime. "El derecho a un juzgamiento especializado de los jóvenes infractores en el derecho comparado".

\subsection{Exigencias más Estrictas para la Renuncia de Derechos que Integran al Debido Proceso}

En el trabajo previo establecimos que la legislación internacional reconocía a niños y jóvenes que son objeto de persecución penal la posibilidad de renunciar a ciertos derechos procesales, especialmente cuando esa renuncia les puede permitir obtener una mejor posición para satisfacer sus intereses. En ese contexto, señalamos que el gran desafío que impone la legislación internacional a los Estados es el de reforzar los mecanismos de aseguramiento de la voluntariedad e información que deben tener los jóvenes al momento de renunciar a un derecho, tomando especialmente en consideración que por su madurez y estado de desarrollo personal no tienen las mismas capacidades que un adulto para comprender las consecuencias de sus decisiones. Señalamos que un caso paradigmático en esta materia está constituido por el derecho a no auto incriminarse, no obstante se trata de un tema que tiene varias otras manifestaciones posibles de ser analizadas. ${ }^{194}$

En lo que sigue analizaremos las condiciones bajo las cuales las legislaciones en estudio permiten la renuncia a este derecho. Es decir, la posibilidad que tienen los jóvenes de no ejercer su derecho a guardar silencio y prestar declaración en el desarrollo de un proceso seguido en su contra.

Tanto en Costa Rica como en España se permite la posibilidad que el joven imputado preste declaración en el desarrollo del proceso, lo que incluye potencialmente la declaración en el momento inicial en que han sido detenidos. Con todo, esta declaración sólo es admisible en la medida en que se prestada con la asistencia de un abogado, lo que establece un sistema de control bastante fuerte destinado a asegurar que el joven tome la decisión de declarar informado acerca de las consecuencias de la renuncia a su derecho. A continuación revisaremos con algo más de detalle cómo se articulan normativamente estas regulaciones. ${ }^{195}$

La LJPJ reconoce el derecho a no auto incriminarse del joven imputado en su artículo 17 al establecer que "Ningún menor de edad está obligado a declarar en contra suyo" y en el artículo 81 inciso segundo que establece que "Los menores de edad pueden abstenerse a declarar". ${ }^{196}$ A su vez, el procedimiento contenido en la LJPJ se estructura sobre de la existencia de una declaración del joven imputado desde etapas tempranas del procedimiento. ${ }^{197}$ En efecto, el artículo 81 establece que una vez que el joven sea puesto a

\footnotetext{
${ }^{194}$ Véase DUCE, cit. nota ${ }^{\text {o }} 1$, pp. 101 y 102.

195 Todas las legislaciones en estudio establecen la obligatoriedad de informar derechos a los jóvenes al momento de su detención o previo a su declaración (incluyendo el derecho a guardar silencio), pero como se trata de una garantía hoy día reconocida también en forma bastante amplia para los adultos no nos detenemos en ella.

${ }^{196}$ Refiriéndose al artículo 17 Tiffer señala que éste contiene uno de los derechos más importantes para el joven imputado y que, por lo mismo, ha sido reconocido en reiterados fallos de la Corte Suprema que ha anulado sentencias basadas en procesos en donde no se respetó adecuadamente este derecho. TIFFER, "La Ley de Justicia", cit. nota no 26, pp. 63 y 64.

${ }^{197}$ Podría afirmarse que se trata de un elemento típico de la estructura de los modelos procesales inquisitivos que todavía perduran en la región como lo es la existencia de una declaración indagatoria inicial a partir de la cual se desarrolla el proceso con posterioridad. En todo caso, en Costa Rica se prohíbe que la policía realice cualquier tipo de interrogatorio al joven detenido. Véase AMADOR, La Detención, cit. nota n 74, p. 203.
} 
Polít. crim. Vol. 7, N 13 (Julio 2012), Art. 1, pp. 1 - 73. [http://www.politicacriminal.cl/Vol_07/n_13/Vol7N13A1.pdf]

la disposición del Juez Penal Juvenil, éste debe -dentro de las 24 horas- proceder a tomarle declaración. ${ }^{198}$ En este escenario, la LJPJ establece diversas regulaciones que pretenden asegurar que el joven pueda ejercer su derecho a no auto incriminarse o renunciar al mismo. El artículo 37 establece que no puede recibirse ninguna declaración a un joven sin que cuente con la asistencia de un abogado. Dicha regla es luego desarrollada con mayor especialidad en los artículos 82 y 83. Ambos artículos se ocupan de la declaración prestada por el niño o joven haciendo una diferenciación si estos tienen más de 12 y menos de 15 (caso en el cual se aplica el artículo 82) y más de quince y menos de 18 (se hace aplicable el artículo 83). La principal diferencia entre ambos estatutos es la aplicabilidad de las reglas de la declaración de adultos o no. Básicamente la LJPJ señala que ellas no se aplican a los menores de 15 y sí a los mayores. Esto ha generado una polémica importante ya que podría ser leído como una restricción de garantías en favor de los niños que se encuentran en una posición más vulnerable. Con todo, como sostiene un autor, la lectura más lógica de la misma no es que se reducen las garantías sino que la declaración debe realizarse en un ambiente de distensión. ${ }^{199}$ Además, ambas normas establecen que la declaración debe producirse -además de en presencia de los abogados- de los padres, tutores, guardadores o representantes. ${ }^{200}$

La LO 5/2000 de España presenta una regulación más sencilla que la de Costa Rica, pero con bastante similitud. Así, el artículo 17.2, que regula la situación de los jóvenes detenidos, establece que declaraciones se llevarán a cabo en presencia de letrado y de aquellos que ejerzan patria y potestad (salvo que las circunstancias no aconsejen la presencia de estos últimos). A falta de estas personas (por ejemplo porque no pudieron ser ubicadas) la LO 5/2000 establece que debe haber presencia de un fiscal distinto al responsable de la instrucción. Como se puede apreciar, se trata de establecer protecciones que son muy superiores a las previstas para adultos ya que involucran a terceros distintos al joven y su abogado.

En los Estados Unidos también es posible encontrar un reconocimiento fuerte del derecho a no auto incriminarse. En efecto, desde Gault en adelante la Corte Suprema de dicho país ha reconocido que en los procesos penales en contra de jóvenes se hace aplicable el derecho a no auto incriminarse, debiendo tenerse presente que varios Estados habían llegado a la misma conclusión en forma previa a dicha decisión. ${ }^{201}$ Las diferencias con los otros países que hemos revisado, significativas en algunos casos, se presentan en el conjunto de protecciones establecidas en favor de los jóvenes para hacer valida su renuncia. En principio, la principal protección está constituida por la obligación que tienen los agentes estatales de informar al joven de sus derechos Miranda antes de proceder a cualquier

\footnotetext{
${ }^{198}$ Se critica esta disposición ya que ella en un sistema acusatorio debiera permitir que sea el fiscal quien toma las declaraciones al joven detenido. Véase AMADOR, La Detención, cit. nota n 74, p. 305.

${ }^{199}$ Véase LLOBET, Javier, "Las Garantías en el Proceso Penal Juvenil", en Derecho Penal Juvenil, San José: DAAD, 2002, p. 170.

${ }^{200}$ El artículo 82 nuevamente tiene una interpretación problemática ya que aparentemente permite la lectura que la participación de los padres, tutores, guardadores o representantes no podrían participar en la declaración a menos que el joven lo solicite de manera expresa, cuando la doctrina parece estar acorde que su presencia debiera ser obligatoria salvo que exista un interés contrapuesto del joven con el resto. Véase AMADOR, La Detención, cit. nota $\mathrm{n}^{0} 74$, p. 307.

${ }^{201}$ BREITENBACH, “Juvenile", cit. nota nº 95, párrafo 24.
} 
DUCE, Mauricio; COUSO, Jaime. "El derecho a un juzgamiento especializado de los jóvenes infractores en el derecho comparado".

interrogación en condiciones de custodia. ${ }^{202}$ Los derechos Miranda incluyen como elemento central la información del derecho a guardar silencio, de que todo lo que diga el joven pueda ser utilizado en su contra, del derecho que tiene de tener un abogado presente en el momento de la interrogación y que ese derecho corre por cuenta del Estado sino tiene medios para solventarlo. ${ }^{203}$ En ese contexto, si el joven decide "voluntariamente" renunciar a sus derechos Miranda, la declaración prestada será legítima y podrá ser utilizada por el sistema. Para determinar la voluntariedad de una confesión, el tribunal respectivo debe ponderar la totalidad de las circunstancias en las que se produjo la declaración ${ }^{204}$, considerando diversos factores vinculados a la madurez, nivel de educación, conocimiento y comprensión de los cargos, entre otros. ${ }^{205}$ Como se puede apreciar, en esta lógica no existe la obligatoriedad de la presencia del abogado u otro tercero como ocurre en España o Costa Rica a menos que el joven así lo exija. Como veremos un poco más adelante, hay varios Estados que han establecido exigencias adicionales que se apartan de este estatuto.

La lógica descrita tiende a ser una reproducción de la forma es que está regulada la renuncia al derecho a guardar silencio en el caso de los adultos. ${ }^{206}$ Con todo, tanto la jurisprudencia como la doctrina, acuerdan que los estándares para analizar la voluntariedad de la renuncia del joven deben tener un cuidado mayor que tratándose de un adulto debido a la especial posición en que se encuentran los primeros. ${ }^{207}$ Aquí aparece un elemento claro de especialidad en el tratamiento en favor de los jóvenes.

Como anticipábamos, diversos Estados han establecido regulaciones más exigentes que la analizada hasta el momento para darle validez a la renuncia del derecho a guardar silencio, fundamentalmente por medio de establecer la necesidad de asesoramiento o la presencia del abogado o una persona adulta responsable del joven al momento de tomar la decisión de prestar declaración. ${ }^{208}$ Un ejemplo a nivel legislativo es el Estado de Colorado en donde se establece como un requisito de admisibilidad de la declaración del joven la presencia de un padre o guardador en el interrogatorio. ${ }^{209}$ Además, es posible identificar varios estados donde es la jurisprudencia la que exige la presencia de un adulto responsable (padre, tutor o

\footnotetext{
${ }^{202}$ Una visión panorámica sobre los derechos Miranda puede revisarse en BAYTELMAN, Andrés, “Tiene Derecho a Guardar Silencio (...) la Jurisprudencia Norteamericana sobre Declaración Policial”, Informe de Investigación $n^{\circ} 13$, Santiago: Centro de Investigaciones Jurídicas de la Facultad de Derecho Universidad Diego Portales, 2002.

${ }^{203}$ Véase GARDNER, Understanding, cit. nota $n^{\circ} 43$, p. 259.

${ }^{204}$ Se trata del mismo test que aplican los tribunales para verificar la admisibilidad de confesiones prestadas por adultos.

${ }^{205}$ Una revisión de diversos factores que han sido ponderados en la jurisprudencia de los Estados Unidos para determinar la voluntariedad de las confesiones puede verse EYINS, D. E., "Voluntariness and admissibility of minor's confession", American Law Reports ALR2d $n^{\circ}$ 87, p. 624 (publicado originalmente en 1963 y actualizado hasta el año 2008).

${ }^{206}$ El caso paradigmático en que este criterio fue desarrollado por la Corte Suprema es Fare v. Michael C. 442 U.S 707 (1979).

${ }^{207}$ En este sentido véase ESTRADA, Francisco, "La Renuncia del Derecho a Guardar a Silencio por un Adolescente en Nuestro Ordenamiento Jurídico y en el Estadounidense. Comentario a propósito del fallo In Re E.T.C Juvenile 141 Vt. 375 (1982) Corte Suprema de Vermont 24 de junio de 1982", en Revista de Derechos del Niño $n^{\circ} 3 / 4$, Santiago 2006, pp. 184.

${ }^{208}$ Véase ESTRADA, cit. nota $\mathrm{n}^{\circ} 207$, p. 189 quien sobre este punto cita a Kevin Morrison.

209 Ídem.
} 
Polit. crim. Vol. 7, No 13 (Julio 2012), Art. 1, pp. 1 - 73.

[http://www.politicacriminal.cl/Vol_07/n_13/Vol7N13A1.pdf]

guardador) e incluso la de un abogado como requisito de validez de la renuncia al derecho a guardar silencio. ${ }^{210}$ El Estado de Vermont es uno de aquellos en los cuales la jurisprudencia ha establecido exigencias adicionales al desarrollo a nivel federal, justificando su posición en el reconocimiento explícito de la diferencia existente entre jóvenes y adultos y la necesidad, a partir de dicha diferencia, de establecer protecciones especiales. ${ }^{211}$ La Corte Suprema de dicho Estado ha sostenido que para renunciar al derecho a ser asesorado por un abogado y a guardar silencio se requiere previamente que el joven sea asesorado o reciba el consejo de un tutor o consejero responsable y que, además, se notifique a su representante antes de cualquier interrogatorio. Se ha establecido también que el adulto que cumple la función de consejero o asesor no sólo debe estar genuinamente interesado en el bienestar del joven sino que ser completamente independiente de la persecución penal y estar informado de los derechos de la persona a quien presta consejo. ${ }^{212}$

En el caso alemán, frente a la pretensión que algún comentarista (bajo una compresión tutelar del "principio educativo") manifestaba hace algunos años, de que los objetivos educativos justificarían que la presión sicológica que el proceso $\mathrm{y}$, particularmente, la prisión preventiva, producían al adolescente fuese aprovechada para provocar en él una "catarsis", que le llevase a "abrirse", reconociendo su responsabilidad (lo que se entendía como un resultado positivo para su "educación"), ${ }^{213}$ en años más recientes se ha impuesto la doctrina conforme a la cual el principio de que nadie está obligado a declarar en su contra, con base constitucional (Arts. 1 y 2 de la Ley Fundamental) y legal ( $\$ \S 136$ y 136a de la $\mathrm{StPO}$ ) en el proceso penal de adultos, también rige plenamente para los adolescentes, y prohíbe restringir el derecho del adolescente a guardar silencio, a consultar con un abogado y a no ser sometido a ningún tipo de métodos de interrogación que afecten su libertad para decidir, por supuestas razones educativas. ${ }^{214}$

Más allá de esta aplicación a los adolescentes de las garantías generales del proceso penal, no hay reglas que explícitamente les den protección reforzada. Pero la doctrina sí da cuenta del desarrollo de interpretaciones de las garantías generales, que atienden a la especial situación del imputado adolescente.

Ello ocurre, por ejemplo, con la determinación del umbral que debe emplearse para dar por presentes en el caso alguno de los métodos de interrogatorio prohibidos por el $\S 136 \mathrm{a}$ de la StPO (como interrogar en situación de agotamiento físico, apremios y afectación relevante al bienestar del imputado, así como de sufrimiento psicológico). ${ }^{215}$

\footnotetext{
${ }^{210}$ Véase GARDNER, Understanding, cit. nota $n^{\circ} 43,243$.

${ }^{211}$ Este desarrollo se encuentra en el caso de la Corte Suprema de Vermont In re E.T.C, 449 A 2 d. 937 (Vt. 1982). Un análisis más detallado del mismo puede revisarse en ESTRADA, cit. nota n 207.

${ }^{212}$ Véase ESTRADA, cit. nota $n^{\circ} 207$, p. 186. In re E.T.C trató de un joven de 14 años respecto del cual el asesoramiento previo estuvo en manos del director del hogar comunitario donde era residente al momento de cometer el delito imputado. El director no le aconsejó sobre el significado y consecuencias de la renuncia a su derecho, en cambio le dijo que fuera "derecho" y "correcto" en la declaración que le tomó la policía en su oficina. Frente a la apelación del joven la Corte Suprema de Vermont estableció que el director del hogar no era un adulto interesado en el bienestar del joven ni completamente independiente de la persecución penal.

213 Así, Brunner, citado por KUHN, Verfahrensfairneß, cit. nota n ${ }^{\circ} 131$, p. 102.

${ }^{214}$ KUHN, Verfahrensfairneß, cit. nota ${ }^{\circ} 131$, pp. 102-103.

${ }^{215}$ Ibíd., pp. 103-104.
} 
DUCE, Mauricio; COUSO, Jaime. "El derecho a un juzgamiento especializado de los jóvenes infractores en el derecho comparado".

También se interpretan de forma especial para el caso de los adolescentes algunas de las reglas que, en el $\S 136$ de la StPO obligan a informar al imputado sobre sus derechos. Una primera precisión que la doctrina hace es que, exigiendo estas normas, más que una información, una "instrucción" (Belehrung) al imputado, ello supone por parte de quien la practica, asegurarse de que el imputado entiende bien aquello sobre lo que se le está instruyendo, con evidentes exigencias especiales de claridad frente a un imputado adolescente $^{216}$.

Por su parte, si bien la aplicación "especializada" de estas reglas ya no parece traducirse en restricciones, "educativamente" fundadas, a la extensión que se da a la información e instrucción (como las que proponía Brunner), sin embargo, algunas zonas grises subsisten, como la declaración del adolescente ante un perito, o ante al representante de la Asistencia a los Tribunales Juveniles que debe efectuar el diagnóstico sobre su desarrollo y sus condiciones de vida e informar al Tribunal, declaración respecto de la cual hay disputa sobre si está sujeta o no al $\S 136$ de la $\mathrm{StPO}^{217}$; en el segundo caso, con todo, parece imponerse la visión de que es obligatorio informar al adolescente sobre sus derechos, al punto de que su omisión se traduce en prohibición de valorar la información ahí obtenida, ${ }^{218}$, si bien la presencia de un defensor sólo tiene lugar excepcionalmente, ante una exigencia explícita del adolescente. ${ }^{219}$

Por último, otro punto en que alguna doctrina plantea la importancia de una interpretación atenta a las particularidades del adolescente, es en la determinación de la frontera entre la "conversación informal" que la policía puede tener con un adolescente, aun no considerado imputado, y el interrogatorio formal, al que debe preceder una instrucción de sus derechos, frontera que, respecto de adolescentes, con menor capacidad para poner límites a la injerencia de la autoridad policial, debe ser adelantada en el tiempo, ${ }^{220}$ de modo que el espacio de "conversación informal" se reduzca drásticamente y al adolescente se le instruya muy pronto sobre sus derechos; todo ello, teniendo en cuenta el peligro de que afirmaciones hechas por el imputado en la conversación informal sean retomadas luego en la interrogación propiamente tal, en perjuicio del imputado. ${ }^{221}$

\section{Segundo Eje: Estrategias Vinculadas a la Estructura General del Procedimiento en el Derecho Comparado}

Un segundo eje de análisis en donde el principio de especialidad tiene un impacto relevante en el diseño de los procesos juveniles está vinculado a la protección de un conjunto de valores propios del sistema juvenil que necesariamente tienen consecuencias procesales, tales como la prioridad de los fines de prevención especial positiva, que, en algunos sistemas comparados se expresa en términos de un "principio educativo". En un trabajo

\footnotetext{
${ }^{216}$ Así lo explicó Ulrich Eisenberg en su entrevista, señalando que la jurisprudencia ha reconocido esta dimensión de la Belehrung.

${ }^{217}$ KUHN, Verfahrensfairneß, cit. nota $\mathrm{n}^{\mathrm{0}} 131$, pp. 105-106 y 108.

218 EISENBERG, Jugendgerichtsgesetz, cit. nota $\mathrm{n}^{\circ} 15, \S 38$ número marginal 43 (con referencias a la decisión BGH NStZ 05, 219).

219 Ibídem.

${ }^{220}$ Ibíd., § 2 número marginal 15.

${ }^{221}$ Así lo aclaró Ulrich Eisenberg, en la entrevista ofrecida.
} 
Polít. crim. Vol. 7, N 13 (Julio 2012), Art. 1, pp. 1 - 73.

[http://www.politicacriminal.cl/Vol_07/n_13/Vol7N13A1.pdf]

anterior se explicó esto con más detalle, por lo que no se volverá aquí sobre ello. En dicha ocasión se identificó tres elementos estructurales de diseño procesal concretos que surgen como consecuencia de la consideración de estos valores específicos que el sistema de justicia juvenil debe satisfacer, se trata de: la flexibilidad del proceso; la protección de la privacidad de los jóvenes y el énfasis en el joven. ${ }^{22}$

En lo que sigue, veremos cómo estos tres aspectos han sido recogidos en el ámbito comparado en las legislaciones en estudio.

\subsection{Necesidad de un Proceso Flexible y Liviano}

La idea que los procesos seguidos en contra de niños y jóvenes presenten niveles mayores de flexibilidad o sean concebidos como "más livianos" que los de los adultos es, en buna medida, una consecuencia de la prioridad de los fines de prevención especial, que impera en los sistemas de justicia juvenil. ${ }^{223}$ Esta es una idea que parece estar asentada claramente en la doctrina de los países objeto de nuestro estudio, si bien, con frecuencia, con una cierta ambigüedad respecto de los fines que persigue.

En el caso alemán, Albrecht sostiene que la doctrina enfatiza que, a partir del "principio educativo", el proceso penal debe ser especialmente elástico y que preceptos rígidos deben mantenerse circunscritos a la medida mínima inevitable pues la hipertrofia de lo formal impide a menudo -ya en el planteamiento- la realización del "principio educativo". ${ }^{224} \mathrm{De}$ ello precisamente deduce la necesidad de una celeridad especial de este tipo de procedimientos. ${ }^{225}$ Este "principio de celeridad" (Beschleunigungsprinzip), como se vio, se fundamenta, en parte, en función de necesidades educativas asociadas a una sanción pronta (para asegurar su "efecto educativo"); en parte, en función de la protección del adolescente en contra de una exposición muy prolongada a la justicia penal o contra la incertidumbre y miedo frente al desenlace que podría tener el proceso. ${ }^{226}$ También se fundamenta, complementariamente, en meras razones de economía procesal. ${ }^{227}$

\footnotetext{
${ }^{222}$ Véase DUCE, cit. nota $\mathrm{n}^{\mathrm{o}} 1$, pp. 103 y siguientes.

${ }^{223}$ Los alcances de esta prioridad por la prevención especial, sea que se le formule en términos de un "principio educativo" o de una orientación hacia la "inserción social" del adolescente, o de otra manera, son objeto de amplio desarrollo y debate, tema sobre el cual no podemos ir en detalle este trabajo. Con todo, parece indiscutible que la búsqueda de efectos positivos en la vida futura del adolescente ("una vida futura sin delitos"), y la evitación de efectos negativos ("desocializadores") es un principio básico sobre el que se construye el sistema penal juvenil. En este sentido se ha dicho "[s]e trata, en definitiva, de un principio configurador del derecho penal juvenil, en tanto afecta todos los ámbitos de este sistema -desde el procesal (celeridad, carácter instructor del fiscal de menores, posibilidad de resolución informal del caso, etc.) hasta el relativo a las consecuencias jurídicas (catálogo variado de medidas, criterios flexibles de aplicación y modificación)-; siendo así que su análisis resulta imprescindible de cara a fijar los criterios que participan en la determinación de la intervención operada sobre el menor infractor" CRUZ, Beatriz, Educación y Prevención General en el Derecho Penal de Menores, Barcelona: Marcial Pons, 2006, p. 23. Información sobre el debate acerca de los alcances del "principio educativo" pueden revisarse en la misma obra, pp. 23-31.

${ }^{224}$ ALBRECHT, Peter-Alexis, El Derecho Penal de Menores, Barcelona, PPU, 1990, p. 407.

${ }^{225}$ Ibíd., p. 408.

${ }^{226}$ Este fin es enfatizado especialmente en la entrevista ofrecida por Ulrich Eisenberg, así como en EISENBERG, Jugendgerichtsgesetz, cit. nota $\mathrm{n}^{\mathrm{o}} 15, \S 55$ número marginal 36.

${ }^{227}$ LAUBENTHAL / BAIER, Jugendstrafrecht. cit. nota $\mathrm{n}^{\mathrm{o}}$ 11, p. 145.
} 
DUCE, Mauricio; COUSO, Jaime. "El derecho a un juzgamiento especializado de los jóvenes infractores en el derecho comparado".

En España, por su parte, Ornosa fundamenta la celeridad, no tanto en la idea de garantía de "plazo razonable" destinada a evitar el estado de incertidumbre generado por el proceso, ni en el desmedro que su extensión podría tener para la presunción de inocencia, sino principalmente en el propósito de asegurar aquella finalidad: “...la actuación judicial debe ser rápida porque el tiempo en los menores no es igual que los adultos y si la respuesta judicial a la comisión de un hecho delictivo se demora en el tiempo, la finalidad educativa que se persigue queda totalmente distorsionada y en muchos casos, puede ser contraria a ese fin". 228

La flexibilidad procesal, con todo, que, como se ve, no siempre se funda en la protección de garantías procesales, a veces parece colisionar con parece entrar en tensión con ellas; por ejemplo cuando a partir de una excesiva celeridad o flexibilidad del procedimiento no se otorgue un espacio real al adolescente para el ejercicio del derecho de defensa. En alguna medida, el debate en los Estados Unidos se orienta en la dirección descrita. En efecto, históricamente en dicho país el proceso juvenil ha sido considerado como un proceso muy dinámico y extremadamente flexible, entregando niveles importantes de discrecionalidad a los jueces para que sea llevado adelante. Con todo, esa discrecionalidad permitió que durante varias décadas se tratara de un proceso con un respeto mínimo de garantías individuales de los jóvenes no obstante estos enfrentar consecuencias igualmente severas que las que se pueden derivar de un proceso penal de adultos. Ello ha llevado a que a partir de Gault, la tendencia del sistema sea reconocer más garantías para limitar la discrecionalidad y de esa manera formalizar un poco más el proceso, el que en todo caso se sigue manteniendo en lo esencial como un procedimiento flexible e informal. ${ }^{229}$ Como se vio, también en Alemania se ha advertido que una dimensión de la flexibilidad, el "principio de aceleración", puede entrar en tensión con las exigencias de un "proceso justo".

En las legislaciones en estudio, nos parece identificar cuatro estrategias procesales específicas que pretenden plasmar esta idea de flexibilidad y sencillez del proceso juvenil.

\subsubsection{Simplificación Procesal}

En primer lugar, están las estrategias que se podrían denominar como simplificación procesal. Es decir, estructurar al procedimiento juvenil desde un modelo simplificado o más sencillo que el proceso de adultos. Esto se logra fundamentalmente eliminando o centrando etapas o pasos procesales, de forma de evitar que por vía de trámites excesivos se produzcan alargamiento innecesario del proceso.

En el caso de Alemania, la simplificación procesal encuentra, en cierto sentido, una primera, y muy temprana (desde 1923, reformada en 1953), expresión en la facultad del juez (independiente de la aplicación del principio de oportunidad por parte del fiscal), de suspender de propia iniciativa (o a iniciativa del fiscal) el proceso formal, para proceder en

\footnotetext{
${ }^{228}$ Véase, ORNOSA FERNÁNDEZ, Derecho, cit. nota n ${ }^{\circ} 32$, p. 101.

229 En este sentido puede consultarse SANBORN, Joseph, "The Right to a Public Jury Trial: a Need for Today's Juvenile Court", Judicature $n^{o} 30$ (1993), p. 230 y ss.
} 
Polít. crim. Vol. 7, N 13 (Julio 2012), Art. 1, pp. 1 - 73.

[http://www.politicacriminal.cl/Vol_07/n_13/Vol7N13A1.pdf]

su lugar a la imposición de una de las "medidas educativas" de la ley (que son consecuencias jurídicas formales, también susceptibles de ser impuestas previa condena) o procurar la conciliación entre el adolescente y la víctima. ${ }^{230}$ Fuera de esa institución, que en cierto sentido puede verse más como una forma de "diversificación procesal", que como una de simplificación del proceso, el principal mecanismo de simplificación procesal, propiamente tal formal, contemplado por la JGG alemana, con su ambivalente fundamentación (respuesta educativa oportuna, protección de garantías, economía procesal), es el procedimiento simplificado (en los $\S 76$ y ss. de la JGG), procedente en los casos en que el fiscal no pida la suspensión del procedimiento, pero tampoco considere necesario seguir un proceso con todas las formalidades del procedimiento intermedio y el juicio oral, y siempre que se trate de casos de criminalidad leve o mediana, en que sea improbable la imposición de una pena juvenil (privativa de libertad), y que no presenten complejidades probatorias. ${ }^{231}$ Sin perjuicio de esta institución, propia del proceso penal de adolescentes, se ha criticado que, en aras de otras particularidades del proceso de la JGG, que atienden a fines distintos, en los proceso penal de adolescentes se excluya, como se vio, la aplicación de instituciones procesales comunes que también están al servicio de la celeridad, como el "procedimiento acelerado" o el "procedimiento por mandato penal". 232

La misma lógica de simplificación procesal inspira el diseño de los procesos en España y Costa Rica. En ambos es posible identificar una orientación simplificadora del proceso establecido en relación a las regulaciones del proceso ordinario para adultos, especialmente en materia del desarrollo de la etapa de investigación.

Como tuvimos oportunidad de mencionar, en España el proceso juvenil se construye a partir del procedimiento abreviado regulado para los adultos en el título II del Libro IV (artículos 757 y siguientes) de la Ley de Enjuiciamiento Criminal. ${ }^{233}$ Se trata de un procedimiento que se utiliza respecto de hechos delictivos con penas potenciales de mediana gravedad, por lo que tiene una vocación por una mayor sencillez en las formas y trámites procesales en general, pero con especial énfasis en la etapa de instrucción. ${ }^{234}$

En el caso de Costa Rica, como señala Tiffer, el diseño del proceso juvenil es muy flexible que el de adultos ya que "...es un proceso que no está estructurado en fases, es un proceso que se diferencia del de adultos porque no tiene un carácter lineal. ${ }^{, 235}$ Esto también se refleja en una tendencia general del proceso de Costa Rica a operar sin una etapa de instrucción demasiado formalizada con posterioridad a la intervención del juez de control de garantías. El reflejo más intenso de esta lógica está contenido en el artículo79 de la LJPJ que regula un procedimiento acelerado tratándose de hechos sorprendidos en flagrancia. En efecto, de acuerdo a esta norma, el Ministerio Público tiene un plazo de cinco días

\footnotetext{
${ }^{230}$ EISENBERG, Jugendgerichtsgesetz, cit. nota $\mathrm{n}^{\circ} 15, \S \S 45$ y 47.

${ }^{231}$ LAUBENTHAL / BAIER, Jugendstrafrecht. cit. nota $\mathrm{n}^{\circ} 11$, p. 145.

${ }^{232}$ MERTENS, Schnell oder gut?, cit. nota n ${ }^{\circ} 128$, pp. 155 y 32 yss.

233 Ídem. P. 99.

${ }^{234}$ De acuerdo al artículo 757 de la Ley de Enjuiciamiento Criminal este procedimiento "se aplicará al enjuiciamiento de los delitos castigados con pena privativa de libertad no superior a nueve años, o bien con cualesquiera otras penas de distinta naturaleza bien sean únicas, conjuntas o alternativas, cualquiera que sea su cuantía o duración."

${ }^{235}$ Véase Entrevista Carlos Tiffer, cit. nota ${ }^{\circ} 9$
} 
DUCE, Mauricio; COUSO, Jaime. "El derecho a un juzgamiento especializado de los jóvenes infractores en el derecho comparado".

siguientes a que el joven haya sido puesto a disposición del Juez Penal Juvenil, es decir, en donde derechamente no se contempla una verdadera etapa de instrucción y se obliga muy rápidamente al fiscal a requerir la realización del juicio.

\subsubsection{Abreviación de Plazos}

Un segundo tipo de estrategias para lograr el objetivo de tener un proceso liviano es el establecimiento de plazos más breves o límites temporales más estrictos para las distintas actividades procesales en el proceso juvenil en relación al de adultos.

Como ya tuvimos oportunidad de revisar en secciones anteriores, especialmente en materia de duración de la prisión preventiva, existe una tendencia importante de las legislaciones en estudio a establecer plazos más acotados que tratándose de la legislación de adultos. Costa Rica y España, parecen claramente caer dentro de esta descripción.

En el caso de Costa Rica, esta tendencia general se refuerza con el artículo 53 LJPJ. Esta disposición regula los casos en donde la ley no establece plazos y le entrega la facultad al juez de fijarlo "racionalmente" para lo cual se establecen como parámetros "la naturaleza del procedimiento y la importancia de la actividad que deba cumplirse." Al incluir el criterio de la "naturaleza del procedimiento" es juez necesariamente debe considerar las características especiales del sistema juvenil que aconsejan contar con plazos más breves que los adultos. En este sentido Tiffer afirma "la autoridad jurisdiccional al fijar los plazos o su extensión debe no sólo considerar la racionalidad, naturaleza e importancia del acto, sino que también debe tomar en cuenta los principios de sumariedad y celeridad del proceso penal juvenil". 236

En el caso de Alemania, como se vio, no se contemplan plazos especiales, más breves, para el proceso, si bien el "principio de celeridad" se traduce, en general, en procesos más reducidos, $\mathrm{y}$, respecto de los adolescentes sometidos a prisión preventiva, rigen los plazos máximos de la legislación procesal penal común (seis meses, prorrogables bajo condiciones relativamente exigentes), además de algunas medidas desarrolladas por la práctica judicial y la jurisprudencia, que tienden a acortar su duración en comparación con los procesos penales seguidos contra mayores de edad.

\subsubsection{Limitación de Sistemas de Impugnación}

Un tercer tipo de estrategias para lograr la rapidez del proceso consiste en el rediseño de los sistemas de impugnación, particularmente de la sentencia definitiva. En efecto, en muchos sistemas jurídicos una buena parte de la extensión de los procesos se explica a partir de la multiplicidad de mecanismos de impugnación disponibles y de las demoras que se producen a partir de la tramitación de los mismos. En consecuencia, una restricción en el uso de los mismos podría traducirse en ganancias importantes en materia de abreviamiento de los plazos de duración de un proceso.

\footnotetext{
${ }^{236}$ Véase TIFFER, “La Ley de Justicia”, cit. nota n 26, p. 116.
} 
Polít. crim. Vol. 7, N 13 (Julio 2012), Art. 1, pp. 1 - 73. [http://www.politicacriminal.cl/Vol_07/n_13/Vol7N13A1.pdf]

Cuando se habla de restricción de vías de impugnación no sólo se está pensando en la eliminación de un recurso específico, sino por ejemplo en limitar sus alcances o contenidos o la legitimación activa del mismo (por ejemplo excluir a los fiscales como potenciales agraviados que pueda recurrir). Una restricción excesiva de recursos podría afectar potencialmente el derecho de un joven de recurrir en contra de una sentencia condenatoria, contemplado como un derecho en los tratados internacionales de derechos humanos.

Dentro de las legislaciones estudiadas es posible notar que en su mayoría el sistema recursivo del proceso juvenil sigue de cerca las pautas del establecido para adultos. Este es el caso de Costa Rica, España y Estados Unidos. El único sistema que presenta diferencias significativas es Alemania, donde, como se vio, la JGG, fuera de eliminar la posibilidad de interponer, sucesivamente, apelación y revisión, que sí se contempla en la legislación procesal penal común, forzando a interponer una u otra (dependiendo del tipo de decisión recurrida) ${ }^{237}$, excluye la posibilidad de recurrir en contra de la determinación de la naturaleza y cuantía de las medidas no privativas de libertad, restricción que, no obstante su positivo efecto en la reducción de la duración del proceso, incluso cuando se fundamenta en el "principio de celeridad", puede ser problemático por entrar en tensión con las exigencias de un "proceso justo" 238 , más problemático todavía parece cuando se la fundamenta en la "necesidad educativa" de mantener ante el adolescente, la "autoridad" del fallo y del juez que lo dictó, o en puras razones de economía procesal. ${ }^{239}$

\subsubsection{Limitación de Contenidos a Discutir en el Proceso Penal Juvenil}

Finalmente, una cuarta posibilidad para lograr un proceso más liviano y breve está en excluir del proceso juvenil algunos debates que normalmente forman parte de los procesos penales de adultos y que, por complejizar los contenidos de la discusión, tienden naturalmente a alargar el desarrollo de las distintas etapas del proceso. La idea entonces es que al limitarse los contenidos a debatir en el proceso esto debiera naturalmente producir una simplificación y acortamiento del mismo.

El ejemplo más paradigmático en este punto está constituido por la determinación de la responsabilidad civil derivada del hecho constitutivo del delito juzgado. Con la excepción del caso de los Estados Unidos, las legislaciones en estudio permiten que en el proceso penal de adultos sea tramitada también la acción civil destinada a establecer la responsabilidad en este ámbito. Se trata de un debate que generalmente agrega aspectos probatorios nuevos no incluidos en la cuestión penal, como también debates jurídicos diversos, por lo que se aumenta la complejidad del proceso.

\footnotetext{
${ }^{237}$ Diferencia que, en opinión de Frieder Dünkel, manifestada en la entrevista que ofreció, debería corregirse asimilando en este aspecto el proceso penal de adultos al de adolescentes, y no al revés, dadas las deficiencias de la apelación y su carácter superfluo frente a la revisión (similar a la nulidad de la legislación procesal penal chilena).

${ }^{238}$ MERTENS, Schnell oder gut?, cit. nota $\mathrm{n}^{\mathrm{0}}$ 128, p. 157.

${ }^{239}$ Críticamente respecto de ambas, en su entrevista, Ulrich Eisenberg sugiere que la primera (la justificación "educativa") es una racionalización - que por lo demás apela a razones inaceptables- de una decisión legislativa fundada, realmente, en la segunda (la finalidad de mera economía procesal).
} 
DUCE, Mauricio; COUSO, Jaime. "El derecho a un juzgamiento especializado de los jóvenes infractores en el derecho comparado".

En este contexto, Costa Rica constituye un ejemplo de esta estrategia de simplificación del procedimiento. En efecto, el artículo 55 de la LJPJ establece que la acción civil destinada a obtener el pago de daños y perjuicios ocasionados por los hechos imputados al joven deben tramitarse ante los tribunales civiles de acuerdo a las reglas establecidas en la legislación procesal civil y con prescindencia de lo dispuesto por la resolución que adopte el Juez Penal Juvenil. ${ }^{240}$ Algo similar ocurre en la legislación alemana ya que de acuerdo al artículo 81 de la JGG no se aplican al proceso penal juvenil las disposiciones de la Ordenanza Procesal Penal en materia de indemnización a la víctima por las consecuencias sufridas por el delito. ${ }^{241}$ En España, la LO 5/2000 permite la discusión de la acción civil (artículos 61 a 64), pero establece que ello debe hacerse en un proceso en un proceso especial y separado del procedimiento penal. ${ }^{242}$ En consecuencia, si bien no se saca completamente el debate de la cuestión civil, al menos se intenta por vía de abrir un cuaderno separado resolver este asunto sin interferir en la parte penal del proceso.

\subsection{Protección de la Privacidad (vida privada)}

Otro mandato central de las normas internacionales en relación a la estructura del proceso es que en éste debe resguardarse al máximo la vida privada de los niños en todas sus etapas. La protección de la privacidad del niño durante el proceso seguido en su contra es un valor del sistema que corre bastante alto y que es propio o específico de los sistemas de responsabilidad juvenil y que encuentra un fuerte reconocimiento en la legislación internacional según se tuvo oportunidad de analizar. ${ }^{243}$ En este marco, la protección de la privacidad del niño presenta tres alcances con implicancias de carácter procesal sobre los cuales analizaremos las legislaciones en estudio.

\subsubsection{Reconocimiento General de la Privacidad}

Un primer elemento en análisis es identificar la manera en que en cada uno de los países es reconocido el derecho del joven a la privacidad. En general, podemos afirmar que las legislaciones en estudio entregan amplio reconocimiento a este derecho en diversas disposiciones legales. Con todo, como veremos más adelante, ellas tienden a regular con más detalle algunas de las manifestaciones específicas de la privacidad y no establecer el ámbito general de la misma.

Dentro de las legislaciones revisadas, la de Costa Rica pareciera ser la que se hace cargo en forma más explícita e intensa del tema en términos de principio general. En efecto, el artículo 20 regula el derecho a la privacidad estableciendo que los jóvenes tienen derecho a que se respete su vida privada y la de su familia, lo que se traduce en la prohibición de

\footnotetext{
${ }^{240}$ Al justificarse esta separación en dos vías de las consecuencias penales y civiles Tiffer señala "Lo anterior es con el fin de que el juez penal se concentre en las consecuencias penales que el hecho ilícito". Véase TIFFER, "La Ley de Justicia”, cit. nota n' 26, p. 118.

${ }^{241}$ Véase CANO PAÑOS, El futuro, cit. nota n ${ }^{\circ} 13$, p. 171.

${ }^{242}$ Un análisis sistemático de todo el régimen de responsabilidad civil y el procedimiento puede verse en Antoni Vaquer, La Responsabilidad Civil, en Justicia Penal de Jóvenes y Menores, Tirant lo Blanch, Valencia 2002, pp. 131 a 152. En el mismo volumen véase también José Luis Cuesta, La Responsabilidad Civil en el Nuevo Proceso Penal de Menores, pp. 311 a 346.

${ }^{243}$ Véase DUCE, cit. nota $n^{\circ} 1$, pp. 106 a 109.
} 
Polít. crim. Vol. 7, No 13 (Julio 2012), Art. 1, pp. 1 - 73. [http://www.politicacriminal.cl/Vol_07/n_13/Vol7N13A1.pdf]

divulgar "la identidad del menor de edad sometido al proceso". El artículo 21 de la LJPJ complementa lo anterior al regular el "principio de confidencialidad", según el cual deben tener tal calidad los datos sobre los hechos cometidos por los jóvenes objeto de persecución penal de conformidad a la LJPJ. Además, se establece la obligación de en todo momento respetar la identidad e imagen del menor de edad. A lo anterior, es necesario agregar lo dispuesto en el inciso segundo del artículo 21 de la LJPJ que establece el deber a los jueces penales juveniles de procurar que la información que brinden sobre estadísticas judiciales no contravenga a los derechos a la privacidad y a la confidencialidad.

Se puede ver que se trata de un nivel de protección bastante intenso. Por ejemplo, como destaca Amador sobre la confidencialidad, ésta no sólo cubre el expediente o carpeta de investigación sino que el dato "En otras palabras la confidencialidad de los datos debe ser guardada por aquellos funcionarios y oficinas que los generaron... Ese mismo alcance tendrá el registro del resultado del proceso seguido en contra del menor de edad, siendo confidenciales los registros donde se archiven dichos datos". ${ }^{244}$

Las disposiciones de la LJPJ se complementan con diversas normas contenidas en el Código de la Niñez y Adolescencia de Costa Rica. El artículo 27 de dicho cuerpo legal contempla la prohibición de difusión de fotografías e imágenes de los jóvenes y la publicación del nombre $\mathrm{u}$ otro dato personal del joven imputado que permita su identificación. El artículo 28 establece la posibilidad de utilizar una medida cautelar de suspensión del acto en el que se infrinjan las prohibiciones del artículo 27. Además, los artículos 188 y 190 establecen sanciones a quienes infrinjan las disposiciones del artículo 27. Para los funcionarios públicos ellas en una falta grave que admite despido justificado y para todo el resto la posibilidad de aplicar una multa. ${ }^{245}$

La jurisprudencia de la Sala Constitucional también ha reconocido la importancia de estas regulaciones. Así, ha sostenido que "Todo menor a que se le imputa la comisión de un hecho punible, es titular del derecho a la intimidad y privacidad de los acontecimientos que tienen relación con el hecho que se le atribuye, de tal razón que en atención a las especiales condiciones de estas personas y con la finalidad de no causar en forma innecesaria una lesión a la honra de éstas, lo dispuesto por estos artículos resulta ser un derecho fundamental que debe protegerse en esta sede...". ${ }^{246}$

En el caso de la legislación Española, el texto original de la LO 5/2000 no establecía ninguna regla general sobre materia de privacidad o confidencialidad. Sólo a partir de la reforma introducida en la LO 8/2006 se avanzó en esta dirección por medio de la incorporación del artículo 35.3 que establece que quienes ejerciten la acción penal deben respetar rigurosamente el derecho del joven a la confidencialidad y a la no difusión de sus datos personales o de los datos que consten en el expediente seguido en su contra. Además, establece que los infractores de esta regla se hacen acreedores de responsabilidades civiles y penales que correspondan. Esto se complementa con el artículo 64.5 que, a propósito del

\footnotetext{
${ }^{244}$ Véase AMADOR, La Detención, cit. nota $\mathrm{n}^{\circ} 74, \mathrm{p} .128$.

${ }^{245}$ Véase LLOBET, Las Garantías..., cit. nota ${ }^{\circ} 199$, pp. 180 y 181.

${ }^{246}$ Sentencia de la Sala Constitucional no $8022-99$ del 15 de octubre de 1999, citada por LLOBET, Las Garantías..., cit. nota ${ }^{\circ} 199$, p. 183.
} 
DUCE, Mauricio; COUSO, Jaime. "El derecho a un juzgamiento especializado de los jóvenes infractores en el derecho comparado".

procedimiento para determinar la responsabilidad civil, señala que al juez le corresponde establecer las condiciones que permiten preservar la intimidad del menor. Se puede apreciar se trata de una regulación más escueta que la de Costa Rica pero orientada en una dirección muy similar.

A nivel federal en los Estados Unidos, la regla de confidencialidad de los procedimientos está regulada en la sección 5038 de la FJDA. El principio rector de la regla es que tanto durante como una vez finalizado el proceso penal juvenil los registros del mismo deben ser salvaguardados frente al acceso de personas "no autorizadas". La regla luego identifica seis casos en los cuáles sí debe darse acceso necesariamente a los registros. ${ }^{247}$ En todo caso, se esclarece que no se liberan los registros tratándose de postulaciones a trabajos, licencias u otros derechos y privilegios.

Según la jurisprudencia asentada en dicho país, dicha regla autoriza como legítimo el establecimiento de confidencialidad de los procesos juveniles, pero no obliga a que esto sea así. En otras palabras, se entrega discrecionalidad al juez para determinar en cualquier momento la necesidad o no que los procesos sean llevados de manera confidencial. ${ }^{248}$ Por lo mismo, se trata de una decisión que debe tomarse caso a caso.

La sección 5038(e) aborda específicamente el tema de la difusión del nombre y fotografías de los jóvenes sujetos al procedimiento juvenil, estableciendo restricciones sobre la misma pero no una confidencialidad absoluta, entregándole también discreción al juez para decidir sobre el tema. ${ }^{249}$ En este sentido, hay jurisprudencia federal que ha señalado que la prohibición de hacer público el nombre o la fotografía de un joven es compatible con la constitución, pero no puede aplicarse a los medios de comunicación del sector privado. ${ }^{250}$

En Alemania, el principio general del proceso penal de adolescentes de exclusión de la publicidad del juicio, también sirve de base a la doctrina, y a alguna jurisprudencia, para afirmar una serie de restricciones que pretenden preservar la privacidad e imagen del adolescente acusado, por ejemplo, la prohibición de divulgar su identidad en los letreros que identifican la causa en los paneles publicados fuera de la sala, o en la citación para una apelación, así como la prohibición a los reporteros, en caso de que por excepción hayan sido admitidos en la sala de juicio, de divulgar cualquier dato o imagen que pueda conducir a la identificación del adolescente. ${ }^{251}$

\subsubsection{Privacidad y Publicidad del Juicio Oral}

Las normas que establecen la privacidad o confidencialidad de los procesos juveniles tienen un impacto muy significativo en una de las características básicas del proceso de adultos: su

\footnotetext{
${ }^{247}$ Se trata en general de investigaciones llevadas a cabo por otros tribunales, agencias de persecución penal o autoridades estatales. También se incorporan hipótesis en los que las víctimas podrían también solicitar. acceso (numeral 6 de la sección). Volveremos sobre algunas de estas hipótesis en la sección siguiente.

${ }^{248}$ Véase RADLER, cit. nota $n^{\circ} 50$, párrafo 8.

249 Ídem.

250 Ídem, párrafo 18.

${ }^{251}$ EISENBERG, Jugendgerichtsgesetz, cit. nota $n^{\circ} 15, \S 2$ número marginal 16 y $\S 48$ número marginal 20.
} 
Polít. crim. Vol. 7, N 13 (Julio 2012), Art. 1, pp. 1 - 73.

[http://www.politicacriminal.cl/Vol_07/n_13/Vol7N13A1.pdf]

publicidad. En las cuatro legislaciones en estudio el carácter público del proceso de adultos, en especial del juicio oral, constituye un punto central de su diseño. En estos mismos países es posible encontrar claras restricciones a dicha publicidad tratándose de juicios seguidos en contra de jóvenes.

El artículo 99 de la LJPJ de Costa Rica regula esta materia en forma específica. Al establecer que la audiencia de juicio deberá ser "oral y privada" so pena de ser declarada nula en caso de incumplimiento. De esta forma la legislación de Costa Rica opta por entregar una mayor al valor de la intimidad que la publicidad del proceso. ${ }^{252}$ En todo caso se entiende que la privacidad de la audiencia no incluye ni a la víctima ni a los padres del acusado que pueden participar en la misma. ${ }^{253}$

En una dirección similar se orienta también la regulación alemana. En efecto, el $\S 48$, párrafo 1, de la JGG regula la no publicidad de las audiencias (señalándose un breve listado de personas habilitadas para presenciarlas, sin perjuicio de la facultad del juez de admitir a otras, por razones especiales, a saber, "fines educativos"), restricción inspirada en el propósito de proteger al adolescente imputado del efecto estigmatizante y de otros menoscabos que un proceso público podría acarrearle, ${ }^{254} \mathrm{o}$ incluso en objetivos vinculados con el éxito de la tarea judicial, en particular, crear mejores condiciones para que el tribunal se haga una idea del grado de desarrollo mental y moral del adolescente (presupuesto de su responsabilidad, conforme al $\S 3$ de la JGG), lo que no es de esperar respecto de un adolescente cohibido o intimidado por la presencia de público. ${ }^{255}$ Con todo, el párrafo 3 de la misma disposición establece una excepción al principio de no publicidad y es que éste no opera cuando en el mismo proceso están involucrado adultos u otros jóvenes adultos (entre 18 y 21 años), ${ }^{256}$ si bien, aun en este caso, el tribunal puede, por razones "educativas" excluir la publicidad. A diferencia de Costa Rica, los efectos de incumplimiento del principio no son tan severos. Tal como lo señala Albrecht, la jurisprudencia ha establecido que una contravención al artículo 48 de la JGG no constituye una causal de casación absoluta sino relativa, ${ }^{257}$ cuyo resultado debe en consecuencia analizarse caso a caso.

La legislación Española presenta una regulación algo distinta en la materia hasta lo que hemos revisado aquí. El artículo 35.2 de la LO 5/2000 establece como punto de partida inicial que la audiencia de juicio es pública de conformidad a las reglas generales. Con todo, admite que el juez autorice que las sesiones no sean públicas "en interés de la persona imputada o la víctima". Se puede apreciar que la lógica es algo inversa a la de países como Costa Rica y Alemania, lo que hace que un sector de la doctrina postule que lo más conveniente es que la regla general fuese inversa. ${ }^{258}$ Debe notarse también que la hipótesis en la que se autoriza la restricción a la publicidad está pensada no solo en favor del imputado, sino que también potencialmente en favor de la víctima. Es decir, las

\footnotetext{
${ }^{252}$ En este sentido véase AMADOR, La Detención, cit. nota $\mathrm{n}^{\mathrm{o}}$ 74, p. 127.

${ }^{253}$ Véase TIFFER, "La Ley de Justicia", cit. nota n ${ }^{\circ} 26,171$.

${ }^{254}$ En este sentido véase ALBRECHT, Jugendstrafrecht, cit. nota $\mathrm{n}^{\mathrm{o}} 21, \mathrm{p} .513$.

${ }^{255}$ EISENBERG, Jugendgerichtsgesetz, cit. nota $n^{\circ} 15, \S 48$ número marginal 8.

${ }^{256}$ Véase CANO PAÑOS, El futuro, cit. nota n ${ }^{\circ} 13$, p. 171.

${ }^{257}$ Véase ALBRECHT, Jugendstrafrecht, , cit. nota $\mathrm{n}^{\mathrm{o}} 21, \mathrm{p} .513$.

${ }^{258}$ Véase ORNOSA FERNÁNDEZ, Derecho, cit. nota n ${ }^{\circ} 32$, p. 402.
} 
DUCE, Mauricio; COUSO, Jaime. "El derecho a un juzgamiento especializado de los jóvenes infractores en el derecho comparado".

restricciones no se justifican exclusivamente en favor del joven objeto de persecución penal.

Junto con lo anterior, el artículo 35.2 de la LO 5/2000 establece una regla de prohibición absoluta a los medios de comunicación de obtener y difundir imágenes del joven y de datos que permitan su identificación. Con esto se limitan los efectos dañinos que potencialmente podría tener la sobre exposición de un joven por haber sido objeto de un juicio público.

Finalmente, en los Estados Unidos también es posible observar una evolución en un sentido diverso a lo ocurrido en países como Alemania o Costa Rica. En este país históricamente los juicios han sido realizados sin público o en reserva, producto más bien del objetivo proteccionista que ha tenido en él la justicia juvenil que como consecuencia del cumplimiento de las disposiciones internacionales en la materia. ${ }^{259}$ Esto se ha traducido en que históricamente la mayoría de las legislaciones estatales hayan tenido como regla general la exclusión del público en los juicios en contra de jóvenes, no obstante entregar cierta discreción al tribunal para admitir a personas que tengan intereses relevantes en el proceso. $^{260}$

En este contexto, el debate en los Estados Unidos en las últimas décadas ha estado más orientado a que se consagre el favor de los jóvenes el derecho a un juicio público y no a la ampliación de la reserva o confidencialidad del mismo. La "lucha política" detrás del debate es lograr la extensión o ampliación a los jóvenes de las garantías del debido proceso reconocidas tradicionalmente a los adultos en base a los mismos principios que justifican la publicidad en tal caso. ${ }^{261}$ En este sentido, por ejemplo, la Corte Suprema del Estado de Alaska ha reconocido el derecho de los jóvenes a un juicio público señalado que "Las razones de las garantías constitucionales del juicio público se aplican tanto a los procesos penales juveniles como a los de adultos. Los procesos penales juveniles, tanto como los de adultos, pueden ser usados como un instrumento de persecución y ser objeto de abuso judicial. El proceso de apelación no es suficiente control de los tribunales juveniles...". ${ }^{262}$ En este sentido, se pretende aumentar el control del trabajo de los tribunales juveniles para eliminar descuidos y abusos, promover el conocimiento público del trabajo y políticas de los tribunales juveniles y mejorar la calidad de la información que aportan los testigos en el juicio. $^{263}$

Un estudio que analiza las legislaciones estatales en la materia constata que al año 1993 sólo siete estados reconocían el derecho al juicio público en favor de los jóvenes imputados. ${ }^{264}$ Con todo, también se constata que ha existido una creciente apertura de los juicios juveniles por vía de cuatro estrategias: (a) reconocimiento del derecho a un juicio

\footnotetext{
${ }^{259}$ En este sentido véase SANBORN, cit. nota $\mathrm{n}^{\circ} 229$, p. 230 y ss.

${ }^{260}$ Véase GARDNER, Understanding, cit. nota $n^{\circ} 43$ p. 271.

${ }^{261}$ La no extensión de la garantía del derecho a un juicio público proviene de la decisión de la Corte Suprema en McKeiver v. Pennsylvania 403 U.S. 528 (1971) por la cual señaló que la garantía de juicio por jurado contemplada en la constitución no era extensible a los jóvenes. Una explicación del desarrollo de la jurisprudencia federal en la materia puede verse en RADLER, cit. nota ${ }^{\circ} 50$, párrafo 6 .

${ }_{262}$ R.L.R. v. State 487 P2d. 27 (Alaska 1971), citado por GARDNER, Understanding, cit. nota n 43, 272.

${ }^{263}$ Véase SANBORN, cit. nota ${ }^{\circ} 229$, p. 236.

${ }^{264}$ Idem p. 233
} 
Polít. crim. Vol. 7, No 13 (Julio 2012), Art. 1, pp. 1 - 73. [http://www.politicacriminal.cl/Vol_07/n_13/Vol7N13A1.pdf]

público en virtud de la enmienda sexta; (b) reconocimiento del derecho de la prensa a presenciar juicios juveniles como consecuencia de la primera enmienda (libertad de expresión); (c) permitir la presencia del público en las salas en donde se realizan juicios juveniles; y, (d) permitiendo la publicación de la identidad del joven o de sus antecedentes o de ambos. En esta dirección, el mismo estudio constata en el año 1993 que 34 jurisdicciones estatales habían avanzado a mayores niveles de publicidad utilizando alguna o varias de estas estrategias, 17 mantenía completa reserva del juicio y otras 16 le habían entregado control a los propios jóvenes sobre la publicidad de las audiencias. ${ }^{265}$

Un área específica en donde se ha producido debate jurisprudencial intenso en los Estados Unidos es acerca de la posibilidad que miembros de la prensa tengan derecho a estar presente en los juicios de jóvenes como consecuencia de la primera enmienda (referida a libertad de expresión), derecho que ha sido reconocido tratándose de los juicios seguidos contra adultos. No ha existido un pronunciamiento explícito de la Corte Suprema Federal en la materia, ${ }^{266}$ pero sí de varias cortes estatales que han dado validez a las leyes locales que prohíben la presencia de la prensa en los juicios juveniles. En dicho contexto, la Corte Suprema Federal ha establecido en Smith v. Daily Mail Publishing ${ }^{267}$ que los estados no pueden imponer penas criminales a los medios de comunicación que publican el nombre de los jóvenes objetos de persecución que hayan sido obtenidos en forma legal. ${ }^{268}$ De esta forma, si bien no se establece su derecho a estar presente en las audiencias, si se les reconoce su derecho a informar respecto de las cuestiones que tomen conocimiento por vías legítimas (por ejemplo lo que les informe un testigo).

\subsubsection{Uso de Antecedentes o Registros del Sistema Juvenil}

Un último aspecto que suele ser cubierto de manera específica por las normas de protección de la privacidad de los jóvenes tiene que ver con el uso de antecedentes o registros como consecuencia de la persecución en contra de un niño. Como señalamos en el trabajo que sirve de base a la presente investigación, la exigencia internacional apunta a impedir que un registro o antecedente juvenil pueda ser invocado en un caso contra la misma persona en el sistema de adultos o al menos a limitarlo en forma importante. ${ }^{269}$ Sobre este asunto, se cuenta con información relevante respecto de Estados Unidos y de Alemania.

A nivel federal, en los Estados Unidos, nuevamente la sección 5038 de la FJDA establece algunas reglas relevantes en la materia que dan cuenta que las posibilidades de limitar el uso de los antecedentes juveniles para persecuciones posteriores son escasos. Como se recordará, el principio general de esta disposición es que los registros del caso juvenil no pueden divulgarse luego de su conclusión, salvo que se trate de personas autorizadas para obtenerlos. La misma sección 5038(a) contiene un listado con las excepciones. Una revisión de las mismas permite apreciar que dentro de las personas autorizadas hay tres hipótesis en las que de manera explícita la apertura de los registros cumple propósitos en

\footnotetext{
${ }^{265}$ Ibídem, pp. 233 y 234.

${ }^{266}$ Véase RADLER, cit. nota ${ }^{\circ} 50$, párrafo 8.

${ }^{267} 443$ U.S. 97 (1979)

${ }^{268}$ Véase GARDNER, Understanding, cit. nota ${ }^{\circ}{ }^{43}$, p. 274.

${ }^{269}$ Véase DUCE, cit. nota $n^{\circ} 1$, p. 109.
} 
DUCE, Mauricio; COUSO, Jaime. "El derecho a un juzgamiento especializado de los jóvenes infractores en el derecho comparado".

persecuciones penales diferentes: (a) cuando se trata de investigaciones llevadas a cabo por otros tribunales (5038 (a) 1); (b) cuando se trata de investigaciones llevadas adelante por agencias encargadas de elaborar un informe presentencial para otro tribunal (5038 (a) 2); y, (c) cuando se trata de investigaciones desarrolladas por agencias de persecución penal (law enforcement agencies) para obtener información relativa a la comisión de un delito (5038 (a) 3).

Sin perjuicio de lo anterior, el problema de la estigmatización de un joven a futuro por los antecedentes de su historial criminal juvenil es reconocido en los Estados Unidos y por eso un número importante de estados ha establecido leyes destinadas a permitir, una vez transcurrido un tiempo desde la condena juvenil sin que se vuelva a cometer delitos, la posibilidad de "limpiar los antecedentes". ${ }^{270}$ Las formas de limpieza de antecedentes adoptan también diversas modalidades: sello de los antecedentes, destrucción, se borran los registros, etc.

En el caso alemán, se parte de la base de una colisión de intereses, en el propio seno de la justicia penal de adolescentes, entre el interés en que los tribunales cuenten en el futuro con información sobre las conductas previas, penalmente relevantes, de un adolescente, y el tipo de reacción de que ellas fueron objeto, por una parte, y la evitación de efectos estigmatizantes del registro de esa información. ${ }^{271}$ Sin embargo, la consideración, empíricamente fundada, de que la mayor parte de la criminalidad de adolescentes es episódica hace que el interés en contar con información, por ejemplo, de quien es "primerizo", decaiga con el tiempo, mientras que su condición de personas en desarrollo puede convertir al registro de sus antecedentes en un impedimento persistente para su futuro laboral y sus posibilidades de desarrollo. ${ }^{272}$ Por ello la Ley del Registro Central Federal contempla disposiciones que privilegian la posición de estos intereses del adolescente, en comparación con las que rigen para condenados mayores de edad; contemplan la existencia de un Registro Educativo, con información sobre las "medidas educativas" impuestas, que no es incorporada en el Registro Central Federal; y permiten la eliminación de las anotaciones penales antes de que se cumplan los plazos generales que permiten cancelar una anotación. ${ }^{273}$

\section{3. Énfasis en el Joven}

Cuando revisamos la legislación internacional identificamos que el sistema para jóvenes infractores opera con un supuesto básico y es que las decisiones que se adopten por parte de las autoridades, particularmente al momento de establecer consecuencia para la conducta que se imputa, se hagan considerando de manera especial las características y necesidades concretas y específicas del joven infractor. A esto lo llamamos el énfasis en el joven. ${ }^{274}$

\footnotetext{
${ }^{270}$ Véase BREITENBACH, "Juvenile", cit. nota $\mathrm{n}^{\circ}$ 95, párrafo 81.

${ }^{271}$ LAUBENTHAL / BAIER, Jugendstrafrecht. cit. nota $\mathrm{n}^{\circ} 11$, p. 357.

${ }^{272}$ Ibídem.

${ }^{273}$ Ibíd., pp. 157-158.

${ }^{274}$ Véase DUCE, cit. nota n ${ }^{\circ} 1$, pp. 109 y 110.
} 
Polít. crim. Vol. 7, N 13 (Julio 2012), Art. 1, pp. 1 - 73. [http://www.politicacriminal.cl/Vol_07/n_13/Vol7N13A1.pdf]

Esta orientación se presenta con fuerza en las cuatro legislaciones en estudio. En Alemania, por ejemplo, sin perjuicio de la importancia creciente que se da a la aplicación de todas las garantías penales y procesal-penales propias del derecho penal y procesal penal común, ${ }^{275}$ es frecuente calificar el Derecho penal juvenil como un "derecho penal de autor", en el sentido de que la orientación a la prevención especial positiva, para promover una vida futura sin delitos, constituye, bajo la idea del "principio educativo", la base de todas las reglas de esa rama del derecho. ${ }^{276}$ Ello se traduce, entre otras consecuencias, en un gran interés por la investigación de las condiciones de vida y estado de desarrollo del autor del delito, a cuyo servicio está la intervención de la Asistencia a los Tribunales Juveniles, formalmente reconocida en la JGG ( $\$ 38 \mathrm{JGG}$ ), en la investigación de esas condiciones y la información al tribunal que debe decidir un curso de acción sobre el adolescente ( $\S 43$ JGG).

En el caso de Costa Rica también se aprecia esta orientación. Así, si se revisa el artículo 122 de la LJPJ de Costa Rica que señala los criterios a considerar para la determinación de sanciones aplicables a los jóvenes se incluyen elementos que tienen un fuerte vínculo con elementos de la personalidad o circunstancias personales que normalmente no se consideran en la determinación de sanciones penales para adultos. Así, la letra a) de dicha disposición señala que debe tenerse en cuenta la vida del menor de edad antes de la conducta punible, la letra d) que debe considerarse la capacidad del joven para cumplir la sanción y la letra e) la edad del menor y sus circunstancias personales, familiares y sociales. De manera similar, el artículo 7.3 de la LO 5/2000 de España señala que para establecer la medida que corresponda aplicar a los jóvenes infractores el juez debe considerar especialmente, además de la prueba y consideraciones jurídicas sobre el hecho, la edad, las circunstancias familiares y sociales, la personalidad y el interés del joven. Detrás de estas normas está la idea que uno de los objetivos centrales del sistema juvenil es lograr el desarrollo integral de la personalidad del joven imputado por el sistema y, por lo mismo, que la consecuencia del proceso no sólo cumple con la función de castigo sino también de educación. ${ }^{277}$

Esta orientación especial de la legislación juvenil se debiera traducir en diversos impactos en el diseño procesal que recojan la posibilidad que el sistema produzca información diversa a la que normalmente se requiere para resolver un caso de adultos y luego permita valorar adecuadamente esa información al momento de tomar las decisiones que correspondan. En lo que sigue, revisaremos dos de estos posibles impactos y la forma en que ellos han sido recogidos en las legislaciones en estudio.

\footnotetext{
${ }^{275}$ KUHN, Verfahrensfairne $\beta$, cit. nota ${ }^{\circ} 131$, passim.

${ }^{276}$ LAUBENTHAL / BAIER, Jugendstrafrecht. cit. nota $\mathrm{n}^{\circ}$ 11, p. 2, citando la doctrina del Tribunal Constitucional Federal alemán.

${ }^{277}$ En este mismo sentido para el caso español véase FERNÁNDEZ, Esther, Entre la Educación y el Castigo: Un Análisis de la Justicia de Menores, Valencia: Tirant lo Blanch, 2008, pp. 149-150. En el caso de Costa Rica es el propio artículo 123 de la LJPJ el que establece que las sanciones establecidas en dicha ley tienen una finalidad primordialmente educativa. En la propia Exposición de Motivos de la LJPJ se desarrolla esta idea cuando se sostiene que "En este sentido, el presente proyecto no pierde ese marcado optimismo en la reeducación y resocialización del joven o adolescente, por el contrario, lo fomenta. Es por ello que se han establecido, por ejemplo, una serie de sanciones, las cuales tienen por objetivo el que venimos exponiendo". Véase en TIFFER, "La Ley de Justicia", cit. nota n 26, p. 253.
} 
DUCE, Mauricio; COUSO, Jaime. "El derecho a un juzgamiento especializado de los jóvenes infractores en el derecho comparado".

4.3.1. Cesura o División del Debate: establecimiento de una fase procesal especial para determinar las consecuencias de la infracción juvenil

Una primera consecuencia procesal tiene que ver con la necesidad del proceso penal juvenil de contar con un procedimiento de determinación de consecuencias o penas más sofisticado que el de los adultos de forma de abrir espacio para la introducción y el debate de información no vinculada con los hechos y la responsabilidad del joven.

De no contar con una fase procesal específica se corre el riesgo de que el conjunto de variables especiales que las legislaciones en estudio establecen para determinar las consecuencias tengan menos posibilidades de ser presentadas y valoradas adecuadamente. Como lo demuestra la experiencia del proceso penal de adultos en la tradición continental o inquisitiva, el concentrar en un mismo debate tanto los aspectos propios de la determinación de responsabilidad (esclarecimiento del hecho y la participación) como los vinculados a la individualización de la pena ha relegado los ejercicios de individualización de la pena a cuestiones muy abstractas o formales. ${ }^{278}$ Para ponerlo de una forma un poco más gráfica, el debate principal sobre responsabilidad ha tendido a "engullirse" al debate sobre determinación de pena. Llevado esto al ámbito juvenil, se traduce en que todos los mandatos de consideración especial del niño para determinar la sanción adecuada se transformen en una pura formalidad. Una solución procesal al problema planteado es la denominada cesura o división del debate de juicio en dos partes distintas, una exclusivamente destinada a la discusión de la responsabilidad y otra a la determinación de consecuencias.

El análisis de las legislaciones en estudio da cuenta de una orientación muy diversa en esta materia. Los tres países de tradición continental (Alemania, España y Costa Rica) mantienen una estructura bastante tradicional en el proceso de determinación de consecuencias o sanciones. De esta forma, el debate del juicio presenta una estructura concentrada que también es común en sus legislaciones procesales de adultos.

Un ejemplo de lo anterior es Costa Rica. La LJPJ no ha establecido la posibilidad de realizar una división del debate, lo que puede apreciarse cuando se revisan las normas que regulan la dinámica del juicio oral y los contenidos que debe tener la sentencia (artículos 100 a 107). Incluso se produce la paradoja en dicho país que el proceso de adultos permite una cesura eventual y el juvenil no la establece. ${ }^{279}$ Otro ejemplo es España, la LO 5/2000 establece en su artículo 39 que una vez concluida la audiencia de juicio el Juez de menores dispone de un plazo de cinco días para dictar sentencia, la que debe resolver sobre la o las medidas propuestas tomando en consideración, entre otros elementos, “...todos los datos debatidos sobre la personalidad, situación, necesidades y entorno familiar y social del menor...". Como se puede apreciar, dicha norma gira en torno a la idea que en la audiencia de juicio deben incorporarse y debatirse todos los elementos especiales para definir la sanción aplicable al joven ya que luego la sentencia que debe ser dictada en un plazo breve debe hacerse cargo de ellos en forma exhaustiva y detallada. En Alemania, por su parte, no

\footnotetext{
${ }^{278}$ Véase MAIER, Derecho Procesal Penal Tomo I, Buenos Aires: Editores del Puerto, 1996, p. 382.

${ }^{279}$ En este sentido véase Entrevista Carlos Tiffer, cit. nota $\mathrm{n}^{\circ}$ 9, quien reconoce que en el caso de adultos no obstante permitirse la división del debate, en la práctica dicha posibilidad no es utilizada.
} 
Polít. crim. Vol. 7, N 13 (Julio 2012), Art. 1, pp. 1 - 73. [http://www.politicacriminal.cl/Vol_07/n_13/Vol7N13A1.pdf]

obstante las detalladas referencias legales a la tarea de investigación sobre la personalidad y condiciones de vida del adolescente, falta una regulación clara de una instancia procesal, como la que en otras jurisdicciones permite la cesura, para debatir específicamente en torno a esas condiciones para la determinación de la sanción; por lo demás, la tarea de la Asistencia a los Tribunales Juveniles, lejos de la lógica de la cesura del debate entre culpabilidad y determinación de pena, abarca simultáneamente la investigación sobre la madurez del adolescente (lo que es condición de su responsabilidad penal, es decir, del juicio de culpabilidad) y sobre las condiciones de vida del mismo, que han de tener una influencia en la determinación de una sanción personalizada. ${ }^{280} \mathrm{Y}$ si bien existe una instancia judicial formal, durante el procedimiento previo (etapa de instrucción), al servicio de la producción de información sobre la personalidad del adolescente, a saber, una declaración judicial especial del adolescente (conforme al $\S 44$ de la JGG) para que el tribunal se forme una "impresión directa" sobre él, nuevamente, lejos de la lógica de la cesura, esta declaración también puede servir al esclarecimiento de su responsabilidad en los hechos. ${ }^{281}$

En el otro extremo se encuentra los Estados Unidos. En dicho país la división o cesura del debate es un elemento característico de su diseño procesal de adultos, el cual proviene de la tradición anglosajona. Así, por ejemplo, se ha sostenido a propósito de la tradición del common law que para ella es "... hasta deseable, disociar la decisión acerca de culpabilidad, de la que se refiere a la pena.". ${ }^{282}$ En materia juvenil la tendencia de las legislaciones estatales ha sido evolutiva. Se ha pasado de tener preferentemente sistemas de audiencias concentradas en la era previa a Gault a contar en la actualidad con sistemas mayoritariamente "bifurcados" de audiencias. ${ }^{283}$ Las dos audiencias son conocidas como audiencia de "adjudicación" (destinada a la determinación de la responsabilidad y que corresponde a la audiencia de juicio más tradicional) y audiencia de "disposición" (destinada a establecer las consecuencias una vez determinada la responsabilidad).

Para comprender bien este diseño procesal es necesario tener presente que el sistema bifurcado no establece solamente la existencia de dos audiencias, sino que en verdad se abre un nuevo procedimiento a partir de la conclusión de la primera audiencia. Este procedimiento tiene por objeto producir información específica sobre la sanción a establecer que luego se discutirá en la segunda audiencia. Además, la segunda audiencia (de disposición) se regirá por reglas algo diversas a las de la audiencia de adjudicación.

Como consecuencia de lo anterior, la audiencia de disposición no se realiza normalmente en forma inmediata a la conclusión de la audiencia de adjudicación sino que transcurrido un cierto plazo que permita su preparación. ${ }^{284}$ Por ejemplo, la FJDA que estable las reglas

280 LAUBENTHAL / BAIER, Jugendstrafrecht. cit. nota $\mathrm{n}^{\mathrm{o}} 11$, pp. 102 y ss.; EISENBERG, Jugendgerichtsgesetz, cit. nota $\mathrm{n}^{\circ} 15, \S 43$ números marginales 9 y ss.

${ }^{281}$ LAUBENTHAL / BAIER, Jugendstrafrecht. cit. nota $\mathrm{n}^{\circ} 11$, como en nota anterior, p. 106.

${ }^{282}$ Véase GARAPON, Antoine; PAPADOPOULOS, Loannis, Juzgar en Estados Unidos y en Francia: Cultura jurídica Francesa y Common Law, Bogotá: Legis, 2006, p. 92

${ }^{283}$ Véase GARDNER, Understanding, cit. nota $\mathrm{n}^{\circ}$ 43, p. 293 y BREITENBACH, "Juvenile”, cit. nota $\mathrm{n}^{\circ}$ 95, párrafo 57.

${ }^{284}$ Por ejemplo como ocurre en la legislación procesal penal de adultos de nuestro país, según lo regula el artículo 343 del Código Procesal Penal. 
DUCE, Mauricio; COUSO, Jaime. "El derecho a un juzgamiento especializado de los jóvenes infractores en el derecho comparado".

para los procesos federales, establece en su sección 5037 que el plazo máximo para realizar esta segunda audiencia es de 20 días desde la finalización de la audiencia de adjudicación (a menos que se está en una situación especial que permita un aumento de dicho plazo). En la audiencia misma, las principales diferencias se producen respecto a las reglas de evidencia que la rigen. Así, en general en estas audiencias se relajan reglas más estrictas de admisibilidad que se aplican en juicio, por ejemplo permitiendo introducir en forma más amplia prueba de referencia. ${ }^{285}$ En algunos estados no se hacen aplicables las reglas de exclusión de prueba, se disminuyen las formalidades para los interrogatorios a los jóvenes y se limitan la posibilidad de contraexaminar testigos. ${ }^{286}$ Finalmente, el estándar de convicción exigido para que el tribunal pueda dar por establecido un hecho que permita tomar la decisión de "disposición" del caso es más bajo que el que se aplica en las audiencias de adjudicación. ${ }^{287}$

\subsubsection{Producción de Información Especializada}

Una segunda derivación relevante para el diseño de los procesos juveniles que surge del énfasis especial que se pone en el joven para determinar las consecuencias de los hechos delictivos que cometen, tiene que ver con la necesidad que surge de producir de información sobre el niño que es objeto de persecución penal que le permita al sistema hacer un ejercicio de individualización adecuado de la respuesta al caso concreto. Se trata de información para determinar la consecuencia y no la responsabilidad.

Este es un tema que presenta ramificaciones tanto orgánicas como procesales en su estudio. Dentro de las orgánicas está el identificar la existencia de normas e instituciones que contemplen la existencia de equipos técnicos especializados o de cuerpos de expertos que tienen por función el producir esta información para ponerla a disposición de fiscales o jueces encargados de llevar adelante el proceso juvenil. En las ramificaciones procesales básicamente lo que se debe observar es la existencia de reglas que regulen la forma de incorporar esta información en el proceso y el rol que ella cumple en las decisiones que se

\footnotetext{
285 En general la prueba de referencia, típicamente el caso de testigos de oídas, es prueba en principio inadmisible en virtud de la regla que prohíbe el hearsay en los Estados Unidos. Esta regla no se aplicaría con el mismo rigor en las audiencias de disposición según la Corte Suprema lo señaló en Gault. Véase BREITENBACH, "Juvenile”, cit. nota n 95, párrafo 75.

${ }^{286}$ Véase GARDNER, Understanding, cit. nota n ${ }^{\circ} 43$, pp. 295 y 296.

${ }^{287}$ Como mencionamos en una sección previa el estándar de convicción en las audiencias de adjudicación es el de "más allá de duda razonable" o en su versión en inglés es "beyond reasonable doubt. En cambio en las audiencias de disposición se suele utilizar el estándar de preponderancia de la evidencia o en su versión en inglés "preponderante of evidence". A grandes rasgos, el estándar de preponderancia de la evidencia es un estándar de convicción relativamente bajo según el cual se exige que para adjudicar un caso a favor de una parte, ésta debe generar en el tribunal un nivel de convicción mayor que la contraparte sobre los hechos argumentados. Si esto pudiera reducirse en una fórmula porcentual se podría afirmar que la parte que es capaz de generar una convicción superior al 50\%, aún cuando sea en un pequeño margen, debiera ser la que gana. Sobre el estándar de convicción aplicado en las audiencias de adjudicación véase BREITENBACH, "Juvenile", cit. nota $n^{\circ} 95$, párrafo 75. Para revisar con poco más de detalle el estándar de "preponderance of evidence" puede revisarse la definición contenida en el Black's Law Dictionary la cual constituye una de las fuentes de referencia más utilizadas en los Estados Unidos. Véase Black's Law Dictionary, $6^{\mathrm{a}}$ edición, ST. Paul Minn.: West Publishing, 1991, p. 819.
} 
Polit. crim. Vol. 7, No 13 (Julio 2012), Art. 1, pp. 1 - 73.

[http://www.politicacriminal.cl/Vol_07/n_13/Vol7N13A1.pdf]

adoptan en su desarrollo. En esta sección nos referiremos sólo a estas cuestiones procesales y no realizaremos un análisis de los aspectos orgánicos.

La revisión de las legislaciones en estudio nos permite constatar que parte de las deficiencias que podrían derivarse de la no existencia de una audiencia especializada para la determinación de las consecuencias en los países de la tradición continental se "compensan" de una manera significativa con una regulación bastante detallada respecto a la necesidad de introducir información especial sobre el joven a la audiencia de juicio concentrada.

Así, como ya se ha señalado, una de las manifestaciones de la especialidad del proceso penal de adolescentes en Alemania es el importante papel asignado a la investigación sobre la personalidad, el desarrollo y el entorno del adolescente imputado, investigación que debe ser llevada a cabo por la Asistencia a los Tribunales Juveniles tan pronto como sea posible ( $\S 38$ y 43 JGG). En todo caso, la investigación de estas circunstancias se realiza bajo la autoridad del fiscal, como órgano encargado, en general, de dirigir las investigaciones durante el procedimiento previo (etapa de instrucción) y, como éste se define mucho más en su rol de órgano acusador, que en un papel de autoridad neutral para la investigación sobre el adolescente, el fiscal tiende a prestar mucho menos atención a esta investigación sobre la persona del adolescente que la que presta a la investigación sobre su responsabilidad en los hechos. ${ }^{288}$ Fuera de ello, debe recordarse que el tribunal también tiene la posibilidad de tomar especialmente declaración al adolescente (conforme al $\S 44$ de la JGG), también (no únicamente) con la finalidad de informarse sobre su personalidad y condiciones de vida; sin embargo, los tribunales rara vez hace uso de esta facultad. ${ }^{289}$

También en la LJPJ de Costa Rica se aprecia un especial interés en producir información sobre el joven acusado. En efecto, el artículo 93 de la misma establece que admitida la acusación a juicio en los casos en los que prima facie se considere que es posible aplicar una sanción privativa de libertad, el Juez penal debe ordenar un estudio psicosocial del joven acusado. Además se señala que en estos casos es un estudio indispensable para dictar la resolución final del caso. Es decir, se eleva a una exigencia de validez de la decisión en los casos en que se podría esperar una sanción de privación de libertad. ${ }^{290}$ Como complemento de lo anterior, el artículo 94 de la LJPJ señala que para la determinar y escoger la sanción el Juez puede remitir al joven al organismo pericial para que se le efectúen exámenes psiquiátricos, físicos y químicos. Se destaca que en especial con el objetivo de detectar adicción a sustancias psicotrópicas. Con todo, esta segunda norma no establece que estos informas sean un requisito de validez de la decisión como en el caso del artículo 93. En todo caso, como puntualiza Tiffer, estos estudios en ningún caso debieran ser utilizados como prueba para determinar la culpabilidad del joven. ${ }^{291}$

\footnotetext{
${ }^{288}$ EISENBERG, Jugendgerichtsgesetz, cit. nota $n^{\circ} 15, \S 43$ número marginal 16.

${ }^{289}$ LAUBENTHAL / BAIER, Jugendstrafrecht. cit. nota ${ }^{\circ} 11$, p. 106.

290 Tiffer describe que la obligatoriedad no era un elemento presente en los proyectos originales de la LJPJ y que estos estudios debieran ser excepcionales y no la regla, sólo cuando sean indispensables para los fines del proceso. Véase TIFFER, "La Ley de Justicia", cit. nota n ${ }^{\circ}$ 26, p. 165.

291 Ídem, p. 166.
} 
DUCE, Mauricio; COUSO, Jaime. "El derecho a un juzgamiento especializado de los jóvenes infractores en el derecho comparado".

En España también se contemplan diversas disposiciones que dan cuenta de la importancia que tiene para el sistema la producción de información especializada para determinar la consecuencia idónea para el joven. La principal está contenida en el artículo 27 de la LO $5 / 2000$ que establece que desde la instrucción del expediente, los fiscales deben requerir al equipo técnico la elaboración de un informe sobre la situación psicológica, educativa y familiar del joven, así como sobre su entorno social y sobre cualquier otras circunstancia relevante para efectos de que se adopten las medidas contempladas en la misma ley. Este informe es considerado un "pilar básico" del sistema ya que permite al fiscal proponer al juez una propuesta educativa idónea a las necesidades del joven en el caso concreto. ${ }^{292} \mathrm{La}$ importancia y rol del informe en el proceso se pueden apreciar luego en diversas disposiciones de la LO 5/2000 que regulan su incorporación al juicio. Así, el artículo 35.1 establece que el juicio debe realizarse en presencia de un representante del equipo técnico que haya elaborado el informe. El artículo 37.2 indica que el en la audiencia de juicio el tribunal debe escuchar al representante del equipo técnico respecto a la procedencia de las medidas propuestas. Finalmente, el artículo 39, referido a los contenidos de la sentencia, indica que el juez debe hacerse cargo en ella toda la prueba producida en el juicio, lo que incluye el informe técnico.

\section{Conclusión}

Para concluir, en estas breves reflexiones finales, quisiéramos ofrecer una mirada general de nuestro objeto de estudio en este trabajo.

Una primera cuestión, anticipada en la introducción, es que la revisión particular de cada país nos muestra que existe una gran diversidad de mecanismos y regulaciones legales en cada uno de ellos, que intentan recoger los distintos ejes de especialidad del proceso penal juvenil sobre los que hemos trabajado en este trabajo. Se trata de una riqueza muy significativa que da cuenta de que aproximarse a un sistema especializado de justicia no pasa necesariamente por una receta única. En este mismo sentido, hemos visto que el derecho internacional de los derechos humanos entrega un margen de apreciación importante a los países para definir su propia estrategia de cumplimiento de los estándares internacionales. ${ }^{293}$ Los países analizados parecen efectivamente buscar a través de caminos propios el logro del ideal especializado.

No obstante esta diversidad, es posible apreciar que algunos mecanismos tienden a repetirse. Por ejemplo, para asegurar que el proceso juvenil sea llevado adelante "sin demora", pudimos observar cómo la técnica de establecer plazos más estrictos que tratándose del proceso penal de adultos era una medida bastante común. Con todo, al examinar cada uno de estos plazos se puede observar nuevamente bastante heterogeneidad en las reglas acerca de la extensión de los mismos, las que además suelen complementarse con otros arreglos legales e institucionales que difieren de país en país. Por lo mismo, la valoración que se puede hacer de esas reglas debe incorporar variables adicionales al mero establecimiento de un plazo específico en la norma respectiva.

\footnotetext{
${ }^{292}$ En este sentido véase ORNOSA FERNÁNDEZ, Derecho, cit. nota nº 32, pp. 341 y 342.

${ }^{293}$ DUCE, cit. nota ${ }^{\text {o }} 1$, p. 81.
} 
Polít. crim. Vol. 7, № 13 (Julio 2012), Art. 1, pp. 1 - 73.

[http://www.politicacriminal.cl/Vol_07/n_13/Vol7N13A1.pdf]

Lo anterior dificulta en extremo el hacer juicios categóricos acerca de la bondad o los problemas de algunos mecanismos específicos contemplados en la legislación comparada, sin contextualizar dicho juicio en la lógica y funcionamiento general del sistema respectivo. De hecho, un problema común que se encuentra en parte de nuestra literatura, consiste en la tendencia a tomar como recetas ciertos desarrollos experimentados en el derecho comparado sin analizar el sentido de esas reglas en el contexto general de su propio sistema.

Esto nos lleva a una segunda observación. La revisión que hemos hecho de la doctrina, jurisprudencia y opiniones de expertos en los países en estudio da cuenta que más allá de las regulaciones legales, en la práctica de todos los sistemas analizados existen fuertes polémicas y varios cuestionamientos a la capacidad de los mismos para cumplir efectivamente varios de los valores recogidos en la legislación internacional. Por ejemplo, la procedencia de la prisión preventiva tratándose de jóvenes infractores sigue siendo, en diversas latitudes, un problema delicado y que no se ha resulto sólo por vía de establecer normas legales más estrictas en relación a su uso. El punto que nos interesa destacar es que, aún en los casos en que algunas reglas aparecen como bien diseñadas, la experiencia de los cuatro países en estudio nos da cuenta de que se presentan brechas importantes entre las regulaciones legales y el asentamiento en la práctica de los principios y valores que están detrás de las mismas. Esto nos entrega una lección importante, que también suele ser olvidada en una parte significativa de la literatura legal en nuestro país: la capacidad limitada que tiene la ley por sí sola para cambiar realidades complejas.

Tomando en consideración las reflexiones anteriores, nos parece que este trabajo debiera contribuir a mejorar la calidad del debate que se está dando en el país en torno a la necesidad de perfeccionar nuestro sistema de justicia juvenil. Creemos que la experiencia comparada, con todas las limitaciones ya indicadas, es rica en la indicación de caminos posibles de acción o, por lo menos, en la enseñanza de experiencias útiles para un sistema tan joven como el nuestro. 
DUCE, Mauricio; COUSO, Jaime. "El derecho a un juzgamiento especializado de los jóvenes infractores en el derecho comparado".

\section{BIBLIOGRAFIA}

ALBRECHT, Hans-Jörg, Ist das deutsche Jugendstrafrecht noch zeitgemäß?, Munich: Beck, 2002.

, "Youth Justice in Germany", en Youth Crime and Youth Justice. Comparative and Cross-National Perspectives, Chicago-Londres: The University of Chicago Press, 2004, pp. 443-493.

ALBRECHT, Peter-Alexis, El Derecho Penal de Menores, Barcelona: PPU, 1990. , Jugendstrafrecht, Múnich: Beck, $3^{\mathrm{a}}$ edición, 2000.

AMADOR, Gary, La Detención Provisional en la Ley de Justicia Penal Juvenil, San José: Editorial Jurídica Continental, 2006.

, "Algunos Problemas Respecto a la Aplicación de la Prisión Preventiva en el Proceso Penal Juvenil", en Revista de Ciencias Jurídicas, n 115, San José, Enero-Abril 2008, pp. 62-65.

ARMIJO, Gilbert, "Las Alternativas a la Detención Provisional”, en Lecciones Aprendidas. Ley de Justicia Penal Juvenil de Costa Rica, San José: UNICEF, 2000.

BAYTELMAN, Andrés, "Tiene Derecho a Guardar Silencio (...) la Jurisprudencia Norteamericana sobre Declaración Policial", Informe de Investigación $n^{o} 13$, Santiago: Centro de Investigaciones Jurídicas de la Facultad de Derecho Universidad Diego Portales, 2002.

BELOFF, Mary, "Los nuevos sistema de justicia juvenil en América Latina (1989-2006)", Justicia y Derechos del Niño n 9, Santiago, 2007, pp. 177-217.

BLUM, George, "Validity and Efficacy of Minor's Waiver of Right to Counsel-Cases Decided Since the Application of Gault", American Law Reports $n^{\circ}$ 101, 2002.

BOCKRATH, Joseph T., Right of Bail in Proceedings in Juvenile Courts, American Law Reports $n^{\circ} 53$ (originalmente publicado en 1973 y actualizado a 2008).

BREITENBACH, Eugene, "Juvenile Court Proceedings", American Jurisprudence Trials, $\mathrm{n}^{\mathrm{o}} 137,2008$ (updated).

CAMPOS, Mayra, "Análisis de la Detención Provisional en Materia Penal Juvenil (1 de enero al 30 de junio de 1998)", en AAVV, Lecciones Aprendidas. Ley de Justicia Penal Juvenil de Costa Rica, San José: UNICEF, 2000, pp. 79-90.

, "El Ministerio Público: Órgano Promotor de la Justicia Juvenil y su Relación con la Policía Judicial", en De la Arbitrariedad a la Justicia: Adolescentes y Responsabilidad Penal en Costa Rica, San José: UNICEF, 2000, pp.385-444.

CANO PAÑOS, Miguel Ángel, El futuro del Derecho penal juvenil europeo. Un estudio comparado del Derecho penal juvenil en Alemania y España. Barcelona: Atelier, 2006.

COUSO, Jaime, "Sustitución y Remisión de Sanciones Penales de Adolescentes, Criterios y Límites para las Decisiones en Sede de Control Judicial de las Sanciones", en AAVV, Estudios de derecho penal juvenil II, Santiago: Centro de Documentación, Defensoría Penal Pública, 2011, pp. 269-355.

, "Límites a la imposición de sanciones privativas de libertad en el Artículo 26 de la Ley de Responsabilidad Penal del Adolescente", Documento de Trabajo $N^{\circ}$ 15, Santiago, Chile: Unidad de Defensa Penal Juvenil, 2009, en AAVV, Estudios de derecho penal juvenil I, Santiago: Centro de Documentación, Defensoría Penal Pública, 2009, pp. 173-229. 
Polít. crim. Vol. 7, N 13 (Julio 2012), Art. 1, pp. 1 - 73.

[http://www.politicacriminal.cl/Vol_07/n_13/Vol7N13A1.pdf]

DAMASKA, Mirjan, The Faces of Justice and State Authority: A Comparative Approach to the Legal Process, New Haven: Yale University Press, 1986.

DÍAZ, Manuel; LUACES, Ana, "El proceso Penal de menores (I)", en Derecho Penal Juvenil, Madrid: Editorial Dykinson, 2007.

DRESSLER, Joshua; MICHAELS, Alan, Understanding Criminal Procedure Vol. 2, New York: Mathew Bender, 2006.

DUCE, Mauricio, "El Derecho a un Juzgamiento Especializado de los Jóvenes Infractores en el Derecho Internacional de los Derechos Humanos y su Impacto en el Diseño del Proceso Penal Juvenil", Ius et Praxis, año 15 - n⿳亠口冋 1 (2009), pp. 73 a 120.

DÜNKEL, Frieder, "Reacciones en los Campos de la Administración de Justicia y la Pedagogía Social a la Delincuencia Infantil y Juvenil: Un Estudio Comparativo a Escala Europea", en: TIFFER, Carlos; LLOBET, Javier; DÜNKEL, Frieder, Derecho Penal Juvenil, San José: ILANUD-DAAD, 2002, pp. 543 a 619.

http://www.rsf.uni-

, Juvenil Justice in Germany, 2005, 42 pp., disponible en

greifswald.de/fileadmin/mediapool/lehrstuehle/duenkel/JuvenileJustice.pdf

[visitada el 07.06.2010].

EISENBERG, Ulrich, Jugendgerichtsgesetz, Munich: Beck, 11 a edición, 2006.

ESTRADA, Francisco, "La Renuncia del Derecho a Guardar a Silencio por un Adolescente en Nuestro Ordenamiento Jurídico y en el Estadounidense. Comentario a propósito del fallo In Re E.T.C Juvenile 141 Vt. 375 (1982) Corte Suprema de Vermont 24 de junio de 1982", en Revista de Derechos del Niño no 3/4, Santiago 2006, pp. 181-196.

EYINS, D. E., "Voluntariness and admissibility of minor's confession", American Law Reports ALR2d $n^{\circ} 87$ (publicado originalmente en 1963 y actualizado hasta el año 2008).

FERNÁNDEZ MOLINA, Esther, Entre la educación y el castigo, Valencia: Tirant Lo Blanch, 2008.

GARAPON, Antoine; PAPADOPOULOS, Loannis, Juzgar en Estados Unidos y en Francia: Cultura jurídica Francesa y Common Law, Bogotá: Legis, 2006.

GARDNER, Martin, Understanding Juvenile Law, New York: Mathew Bender, 1997.

GÓMEZ COLOMER, Juan Luis, "Tuición Procesal Penal de Menores y Jóvenes", en Justicia Penal de Menores y Jóvenes, Valencia: Tirant lo Blanch, 2002, pp.155-193.

HINZ, Werner, "Nebenklage im Verfahren gegen Jugendliche, Gedanken zum neuen $§ 80$ Abs. 3 JGG", en Juristische Rundschau, $n^{\circ} 4$ (2007).

KRISBERG, Barry, "Rediscovering the Juvenile Justice Ideal in the United States", en Comparative Youth Justice, London: Sage, 2006, pp. 6-18.

KUHN, Thomas, Verfahrensfairneß im Jugendstrafrecht. Das deutsche Recht und das Recht der USA im Vergleich, Munich: VVF, 1996.

LAUBENTHAL, Klaus; BAIER, Helmut, Jugendstrafrecht, Springer: Berlín-HeidelbergNueva York, 2005.

LlOBET, Javier, Derecho Procesal Penal: Garantías Procesales (segunda parte), San José: Editorial Jurídica Continental, 2007.

, "La Detención provisional en la Justicia Penal Juvenil", en AAVV, Derecho Penal Juvenil, San José: DAAD, 2002, pp. 203-250.

, "Las Garantías en el Proceso Penal Juvenil", en Derecho Penal Juvenil, San José: DAAD, 2002, pp. 141-201. 
DUCE, Mauricio; COUSO, Jaime. "El derecho a un juzgamiento especializado de los jóvenes infractores en el derecho comparado".

MAIER, Derecho Procesal Penal Tomo I, Buenos Aires: Editores del Puerto, 1996.

MERTENS, Andreas, Schnell oder gut? Die Bedeutung des Beschleunigungsgrundsatzes im Jugendstrafverfahren, Frankfurt: Peter Lang, 2003.

MUNCIE, John; GOLDSON, Barry (Eds.), Comparative Youth Justice, Londres: SAGE, 2006.

MUÑOZ CONDE, Francisco, "Recensión: VORMABUM, Thomas. Einführung in die moderne Strafrechtsgeschichte (Introducción a la Moderna Historia del Derecho Penal)". Polit. crim. $\mathrm{n}^{\mathrm{o}}$ 7, (2009), R1-7, pp. 1-16, en: http://www.politicacriminal.cl/n_07/r_1_7.pdf [visitado el 3.12.2011].

ORNOSA FERNÁNDEZ, María Rosario, Derecho Penal de Menores, $4^{\mathrm{a}}$ edición, Barcelona: Bosch, 2007.

PELÁEZ, Vicente, "La Intervención del Abogado en la Justicia de Menores en España", en Los Derechos de los Niños: Perspectivas Sociales Políticas Jurídicas y Filosóficas, Madrid: Editorial Dykinson, 2007.

RADLER, Jean, "Treatment Under Federal Delinquency Act (18 U.S.C.A 5031-5042) of Juvenile Alleged to Have Violated Law of United States", en American Law Reports Federal, no 137 (1997).

ROJAS, Alejandro, "El Derecho de Defensa en el Proceso Penal Juvenil Costarricense", en: GONZALEZ, Mauricio; TIFFER, Carlos (Coords.) De la Arbitrariedad a la Justicia: Adolescentes y Responsabilidad penal en Costa Rica, San José: UNICEF, 2000, pp. 333 a 384.

ROXIN, Claus, Strafverfahrensrecht. 24ª edición, Múnich: Beck, 1995.

SANBORN, Joseph, "The Right to a Public Jury Trial: a Need for Today's Juvenile Court", Judicature $n^{\circ} 30$ (1993).

SCHAFFSTEIN, Friedrich; BEULKE, Werner, Jugendstrafrecht, Eine systematische Darstellung, Stuttgart: Kohlhammer, 14 edición, 2002.

SHEPHERD, Robert, "Still Seeking the Promise of Gault: Juveniles and the Right to Counsel", Criminal Justice Magazine, vol. $18 \quad \mathrm{n}^{\mathrm{o}} 2$ 2003, en: http://www.americanbar.org/tools/digitalassetabstract.html/content/dam/aba/publishing/criminal_justic e_magazine/crimjust_mo_premium_cr_cjmag_18_2_promiseofgault.pdf [visitado el 16.04.2012].

SHEPHERD, Robert, "Speedy Trials for Juveniles", Criminal Justice Magazine vol. 4 n 4 (2000), en: http://www.abanet.org/crimjust/juvjus/speedytrial.html [visitado el 10.07.2009].

$\begin{array}{cccc} & \\ \text { Magazine } & \text { "Juveniles' Waiver of the Right to Counsel”, Criminal Justice } \\ n^{\circ} & 1 & \text { Vol. } & 13\end{array}$ http://www.americanbar.org/publications/criminal_justice_magazine_home/crimjust_ juvjus_13_1jwr.html [visitada El 16.04.2012].

SCHWARTZ, Allan L., "Failure to give adequate notice to juvenile's parents as ground for reversal of determination of juvenile delinquency under Federal Juvenile Delinquency Act (18 U.S.C.A. $\S \S 5031$ to 5042)", American Law Reports ALR Federal n 30, 475 (publicado originalmente el año 1976).

STROBEL, Sonia, Verhängung und Bemessung der Jugendstrafe - Eine Analyse unter besonderer Berücksichtigung der Strafzwecke. Aachen, Alemania: Shaker Verlag, 2006. 
Polít. crim. Vol. 7, № 13 (Julio 2012), Art. 1, pp. 1 - 73.

[http://www.politicacriminal.cl/Vol_07/n_13/Vol7N13A1.pdf]

TAMARIT, Joseph, "Principios Político Criminales y Dogmáticos del Sistema Penal de Menores", en Justicia Penal de Menores y Jóvenes, Barcelona: Tirant Lo Blanch, 2002, pp. 13-46.

TIFFER SOTOMAYOR, Carlos, Ley de Justicia juvenil, $2^{\circ}$ Edición, San José: Juristexto, 2004.

, "La Ley de Justicia Penal Juvenil dentro de los modelos teóricos de política criminal y fuentes legales", en: De la Arbitrariedad a la Justicia: adolescentes y Responsabilidad Penal en Costa Rica., Serie de Políticas \#5, San José: Unicef, 2000, pp. 91-180.

TONRY, Michael; DOOB, Anthony (Eds.), Youth Crime and Youth Justice: Comparative and Cross-National Perspectives, Chicago: The University of Chicago Press, 2004.

VO $\beta$, Michael: Jugend ohne Rechte. Die Entwicklung des Jugendstrafrechts, FrankfurtNew York: Campus Verlag, 1986.

VORMBAUM, Thomas, Einführung in die moderne Strafrechtsgeschichte, $2^{\mathrm{a}}$ edición, Berlín-Heidelberg: Springer Verlag, 2011. 